\title{
International Union of Basic and Clinical Pharmacology. LXXVI. Current Progress in the Mammalian TRP Ion Channel Family
}

\author{
Long-Jun Wu, Tara-Beth Sweet, and David E. Clapham \\ Howard Hughes Medical Institute, Department of Cardiology, Manton Center for Orphan Disease, Children's Hospital Boston and \\ Department of Neurobiology, Harvard Medical School, Boston, Massachusetts
}

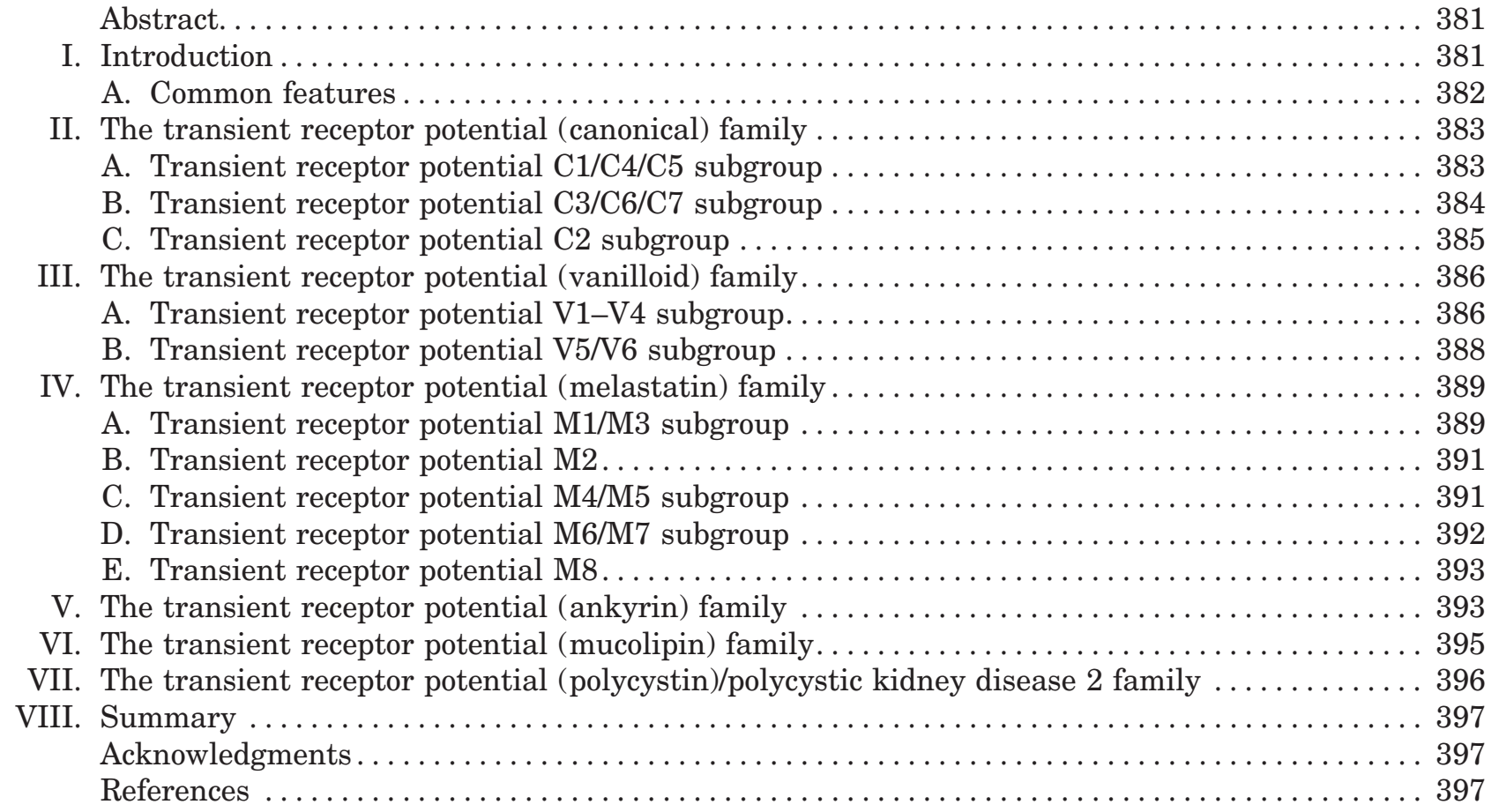

\begin{abstract}
Transient receptor potential (TRP) channels are a large family of ion channel proteins, surpassed in number in mammals only by voltage-gated potassium channels. TRP channels are activated and regulated through strikingly diverse mechanisms, making them suitable candidates for cellular sensors. They respond to environmental stimuli such as temperature, $\mathrm{pH}$, osmolarity, pheromones, taste, and plant compounds, and intracellu-
\end{abstract}

lar stimuli such as $\mathrm{Ca}^{2+}$ and phosphatidylinositol signal transduction pathways. However, it is still largely unknown how TRP channels are activated in vivo. Despite the uncertainties, emerging evidence using TRP channel knockout mice indicates that these channels have broad function in physiology. Here we review the recent progress on the physiology, pharmacology and pathophysiological function of mammalian TRP channels.

\section{Introduction}

Unlike most ion channels, $\mathrm{TRP}^{1}$ channel family members are identified by their sequence homology rather than

Address correspondence to: Dr. David E. Clapham, Howard Hughes Medical Institute, Department of Cardiology, Children's Hospital Boston, 1309 Enders Research Building, 320 Longwood Avenue, Boston, MA 02115. E-mail: dclapham@enders.tch. harvard.edu

L.-J.W. and T.-B.S. contributed equally to this work.

This article is available online at http://pharmrev.aspetjournals.org. doi:10.1124/pr.110.002725.

\begin{abstract}
${ }^{1}$ Abbreviations: 2-APB, 2-aminoethoxydiphenyl borate; ADPKD, autosomal dominant polycystic kidney disease; CaM, calmodulin; CIRB, $\mathrm{CaM} / \mathrm{IP}_{3} \mathrm{R}$-binding; $\mathrm{CSNB}$, congenital stationary night blindness; DAG, diacylglycerol; EPSC, excitatory postsynaptic current; GSK1016790A, $(N$-((1S)-1-\{[4-((2S)-2-\{[(2,4-dichlorophenyl)sulfonyl]amino\}-3-hydroxypropanoyl)-1-piperazinyl]carbonyl\}-3-methylbutyl)-1-benzothiophene-2-carboxamide; HC-030031, 2-(1,3-dimethyl-2,6-dioxo-1,2,3,6tetrahydro-7H-purin-7-yl)- $N$-(4-isopropylphenyl)acetamide; HEK, human embryonic kidney; $\mathrm{IP}_{3} \mathrm{R}$, inositol trisphosphate receptor; mGluR1, metabotropic glutamate receptor 1; MLIV, mucolipidosis type IV; OMIM, Online Mendelian Inheritance in Man; $\mathrm{PIP}_{2}$, phosphatidylinositol 4,5-bisphosphate; PKD, polycystic kidney disease; PLC,
\end{abstract}


by ligand function or ion selectivity. To date, $\sim 30$ mammalian TRP channels have been identified and are grouped into six subfamilies on the basis of amino acid sequence homology: TRPC ("canonical"), TRPM ("melastatin”), TRPV ("vanilloid”), TRPA ("ankyrin"), TRPML ("mucolipin"), and TRPP (or PKD) ("polycystin") (Clapham et al., 2005).

\section{A. Common Features}

TRP channels conduct cations and, when activated, depolarize cells. If, as a result, TRP channel-mediated intracellular $\mathrm{Ca}^{2+}$ induces increases above basal levels $(\sim 100$ $\mathrm{nM}$ ), they initiate a plethora of cellular responses. They are commonly found in epithelial cells but can be found in all cell types. Most TRP channels are weakly voltage-sensitive and nonselective, with $\mathrm{P}_{\mathrm{Ca}} / \mathrm{P}_{\mathrm{Na}}<10$, with the exception of the monovalent-selective TRPM $3 \alpha 1$, TRPM4, and TRPM5 $\left(\mathrm{P}_{\mathrm{Ca}} / \mathrm{P}_{\mathrm{Na}}<0.05\right)$ and the $\mathrm{Ca}^{2+}$-selective TRPM3 $\alpha 2$, TRPV5, and TRPV6 $\left(\mathrm{P}_{\mathrm{Ca}} / \mathrm{P}_{\mathrm{Na}}>100\right)$. Based on extensive work on other members of the voltage-ligand-gated superfamily of ion channels (Yu et al., 2005) and TRP channel primary sequences, they are assumed to have six transmembrane (TM) spanning domains (S1-S6) with a pore domain between the fifth (S5) and sixth (S6) segments and both $\mathrm{C}$ and $\mathrm{N}$ termini located intracellularly. The cytoplasmic end of the S6 helices seem to form the lower gate, which opens and closes to regulate cation entry into the channel. The S1-S4 domain may gate the pore in response to ligand binding, but the paucity of positively charged arginines in S4 helices indicates weak voltage sensitivity of TRP channels. All elements outside the S5-S6 region provide means of either subunit association or act as linkers to elements that control gating. Other structural features of TRP channels include 1) a 25-amino acid TRP domain containing a TRP box (EWKFAR) just C-terminal to S6 in TRPC (also in TRPV and TRPM, but less conserved); 2) ankyrin repeats in the $\mathrm{N}$-terminal cytoplasmic domain of TRPC, TRPV, and TRPA; and 3) proline-rich regions in the region just C-terminal to $\mathrm{S} 6$ in TRPC, TRPM, and in some TRPVs (Clapham, 2003; Ramsey et al., 2006).

Although some TRP channels clearly function as chemosensors for exogenous ligands, relatively few endogenous ligands are known for TRP channel activation. Therefore, one of the central unanswered questions in the field is how TRP channels are normally activated in vivo. Many TRP channels are potentiated by phospholipase $\mathrm{C}$ activation. Large classes of $\mathrm{G}$ protein-coupled receptors $\left(\mathrm{G}_{\mathrm{q} / 11}\right.$; linked to $\left.\operatorname{PLC} \beta\right)$ and tyrosine kinase receptors (linked to $\mathrm{PLC} \gamma$ ) potentiate most TRP channels. However, the mechanism of this

phospholipase C; SKF96365, 1-( $\beta$-[3-(4-methoxyphenyl)propoxy]4-methoxyphenethyl)- $1 H$-imidazole; TM, transmembrane; TRP, transient receptor potential; TRPA, transient receptor potential ankyrin; TRPC, transient receptor potential canonical; TRPM, transient receptor potential Melastatin; TRPML, transient receptor potential mucolipin; TRPP, transient receptor potential polycystin; TRPV, transient receptor potential vanilloid. potentiation is not well understood (Trebak et al., 2007). Elements of the phosphatidylinositol signaling pathway are closely linked to the plasma membrane and also seem to regulate many TRP channels. In particular, $\mathrm{PIP}_{2}$, a common regulator of ion channels, potentiates most TRP channel activity (Voets and Nilius, 2007). In addition, intracellular $\mathrm{Ca}^{2+}$ increases the activity of some mammalian TRP channels and modulates practically all TRP channels. Regulation by phosphorylation, $\mathrm{PIP}_{2}$, and $\mathrm{Ca}^{2+}$ are common to ion channels and are not specific features of the TRP class of channels.

A common problem in the TRP field is the lack of specific pharmacological tools, leading to the dependence on highly nonspecific blockers, such as ruthenium red (which binds most $\mathrm{Ca}^{2+}$ binding sites in proteins), 2-APB, flufenamate, niflumic acid, and 1-( $\beta$ [3-(4-methoxyphenyl)propoxy]-4-methoxyphenethyl)$1 H$-imidazole (SKF96365). More useful tools include capsaicin, a fairly specific agonist of TRPV1, and 2-(1, 3-dimethyl-2,6-dioxo-1,2,3,6-tetrahydro-7H-purin-7yl)- $N$-(4-isopropylphenyl)acetamide (HC-030031), a relatively specific antagonist of TRPA1 (Caterina et al., 1997; McNamara et al., 2007). $\mathrm{La}^{3+}$ is useful in recognizing TRPC4 or TRPC5 because it potentiates these channels and blocks most other TRP and $\mathrm{Ca}^{2+}$. permeant channels (Strübing et al., 2001). TRP channel antagonists with higher selectivities and potencies are being developed in the pharmaceutical industry but most are currently unavailable for academic research. The dearth of useful pharmacological tools forces reliance on small interfering RNA and genetic strategies, but these methods do not replace the usefulness of blockers and antagonists. There is currently significant disagreement on the assembly, localization, and function of TRP channels. This confusion has been created by nonspecific antibodies, lack of precise pharmacological tools, and over-reliance on indirect $\mathrm{Ca}^{2+}$ measurements rather than direct measurement of currents.

Indeed, emerging evidence using knockout mice has revealed the very diverse functions of TRP channels (Moran et al., 2004; Desai and Clapham, 2005; Venkatachalam and Montell, 2007). Human genetics has further uncovered potential TRP channel functions. For example, 13 channelopathies have been proposed to stem from mutations in TRP genes: focal segmental glomerulosclerosis 2 (OMIM 603965), caused by TRPC6 mutations; Charcot-Marie-Tooth disease type 2C (OMIM 606071) and scapuloperoneal spinal muscular atrophy (OMIM 181405), caused by TRPV4 mutations; congenital stationary night blindness (OMIM 301500), caused by TRPM1 mutations; progressive familial heart block type 1 (OMIM 113990), caused by TRPM4 mutations; autosomal-recessive hypomagnesemia with secondary hypocalcemia (OMIM 602014), caused by TRPM6 mutations; amyotrophic 
lateral sclerosis-Parkinsonism/dementia complex (OMIM 105500), caused by TRPM2 or TRPM7 mutations; brachyolmia type 3 (OMIM 113500); mucolipidosis IV (OMIM 252650), caused by TRPML1 mutations; Kozlowski type of spondylometaphyseal dysplasia (OMIM 184252); metatropic dysplasia (OMIM 156530); congenital distal spinomuscular atrophy (OMIM 600175); autosomal dominant polycystic kidney disease (OMIM 173910), caused by TRPP1 or TRPP2 mutations; and familial episodic pain syndrome, caused by a TRPA1 mutation. The function of TRP channels in vivo is the current focus in the field. Here we summarize recent progress on the physiology, pharmacology, and pathophysiological function of mammalian TRP channels.

For detailed tables of TRP genes, accession numbers, splice variants, domains, biophysical properties, and pharmacology, see http://www.iuphar-db.org/ DATABASE/FamilyIntroductionForward?familyId = 78 and http://clapham.tch.harvard.edu. There are many excellent comprehensive reviews on TRP channel domain structure, channelopathies, pharmacology, and neuronal TRPs (Venkatachalam and Montell, 2007; Talavera et al., 2008; Latorre et al., 2009; Nilius and Owsianik, 2010).

\section{The Transient Receptor Potential (Canonical) Family}

Seven mammalian TRPC proteins (TRPC1-7; Fig. 1) have been identified, but TRPC2 is a pseudogene in humans. These channels can be divided into three subgroups by sequence homology: $\mathrm{C} 1 / \mathrm{C} 4 / \mathrm{C} 5, \mathrm{C} 3 / \mathrm{C} 6 / \mathrm{C} 7$, and
C2. All mammalian TRPC proteins seem to be potentiated by stimulation of G-protein-coupled receptors and receptor tyrosine kinases.

\section{A. Transient Receptor Potential C1/C4/C5 Subgroup}

TRPC1 was the first member of the mammalian TRPCs purported to form an ion channel (Zitt et al., 1996). However, whether TRPC1 can form functional homomeric channels by itself remains debatable. Although homomeric TRPC1 was proposed to be a storeoperated channel or stretch-activated channel (Zitt et al., 1996; Maroto et al., 2005), heterologous overexpression of TRPC1 has produced no measurable currents distinguishable from background leak (Lintschinger et al., 2000; Strübing et al., 2001). It is possible that TRPC1 homomeric channels are functional, but the activating stimulus has not yet been found. Alternatively, TRPC1 may function as a homomer in the endoplasmic reticulum and reach the plasma membrane only when coassembled with other TRP subunits. A more detailed examination of previously proposed homomeric TRPC1 channels is required before TRPC1 can be assumed to form a plasma membrane channel by itself.

TRPC1 forms heteromeric channels with $\mathrm{C} 4$ or C5, which have properties distinct from those of homomultimers (Lintschinger et al., 2000; Strübing et al., 2001). The existence of TRPC1 and C4 or C5 heteromeric channels is supported by the following evidence: 1) TRPC1 coexpressed with TRPC4 or TRPC5 form current-voltage relationships distinct from TRPC4 or TRPC5 expressed alone; 2) single-channel currents from TRPC1 coexpressed with TRPC 4 or TRPC5 have

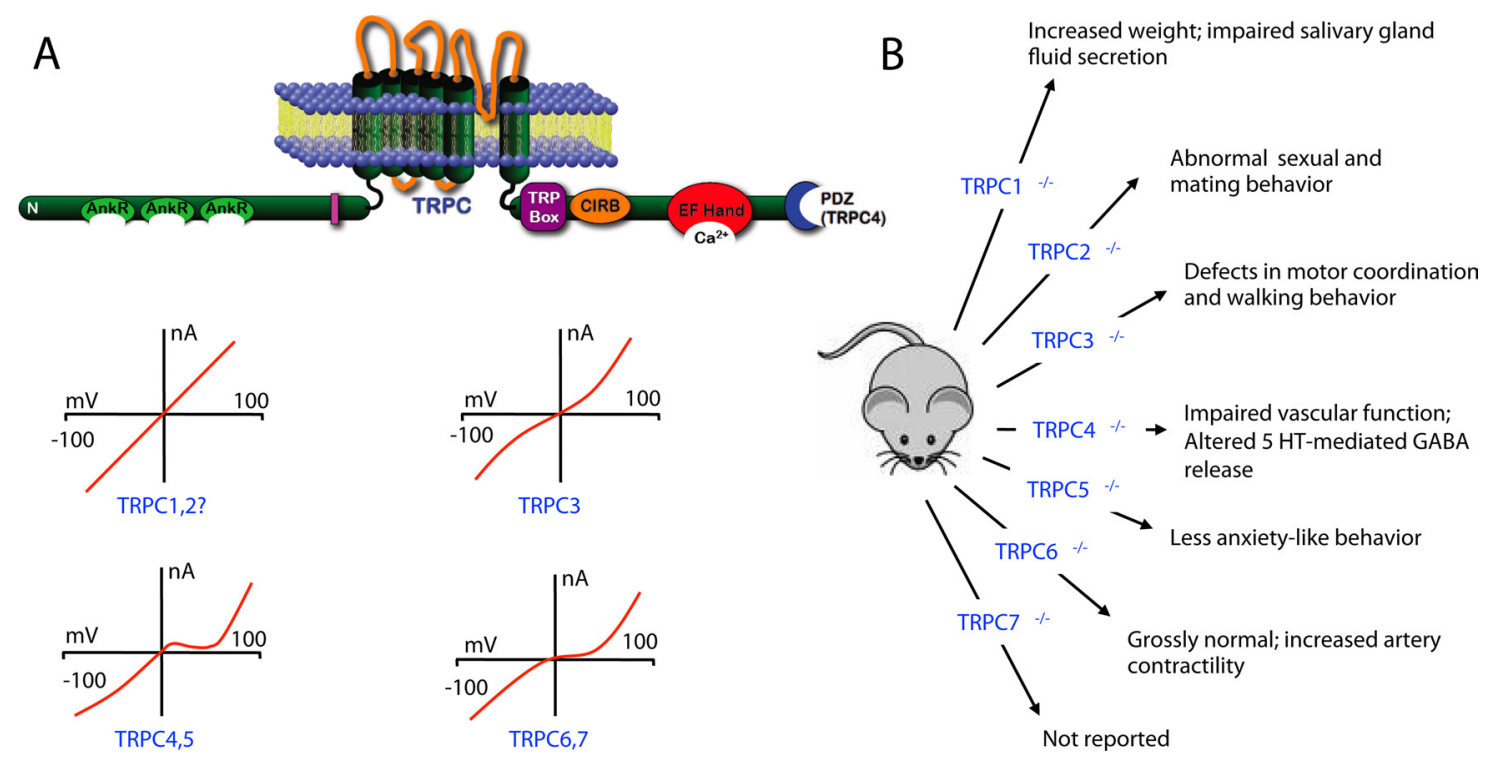

FIG. 1. TRPC (canonical) family. A, molecular domains of TRPC channels and their current-voltage relationships. The TRP box is a conserved region in TRPC, TRPV, and TRPM families; its function is unclear, but it may bind PIP $_{2}$. CIRB refers to a calmodulin/IP ${ }_{3} R$-binding $(C I R B)$ domain. The EF hand is a helix-loop-helix structural domain found in a large family of calcium-binding proteins. PDZ (postsynaptic density 95/disc-large/zona occludens) is a common protein interaction motif that holds together signaling complexes. In this and the following figures, steady state currentvoltage curves are shown. B, results of genetic deletion experiments. The $\operatorname{Tr} p C 7(-/-)$ phenotype has not been reported. TrpC2 is a pseudogene in humans. 
clearly distinct conductances from TRPC4 or TRPC5 homomeric currents; 3) TRPC1 coimmunoprecipitates with TRPC4 or TRPC5 when purified from brain, and; 4) in hippocampal neurons, TRPC1/C4 or TRPC1/C5 heteromeric channels seem to localize to the cell bodies of neurons, whereas TRPC4 or TRPC5 can reside in both the cell body and the periphery (dendrites, axons) (Strübing et al., 2001, 2003). Therefore, given the wide expression of TRPC1 and its ability to coassemble with other TRPC subunits, TRPC1 might be a component of different heteromeric TRP complexes.

TRPC4 and TRPC5 are close homologs, sharing 64\% identity. Both TRPC4 and TRPC5 contain a Cterminal PDZ-binding motif (VTTRL). PDZ domain scaffolding proteins, such as $\mathrm{Na}^{+} / \mathrm{H}^{+}$exchanger regulator factor, as well as signaling molecules such as PLC $\beta 1$, have been reported to coimmunoprecipitate with TRPC4 and TRPC5 (Tang et al., 2000). TRPC4 and TRPC5 channels also share many functional characteristics, are both potentiated by GPCRs that couple to $\mathrm{G} \alpha_{\mathrm{q} / 11}$, and have similar current-voltage relationships (Okada et al., 1998; Schaefer et al., 2000). Although activation of these channels seems to require PLC enzymatic activity, their direct agonists are still unknown (Hofmann et al., 1999; Schaefer et al., 2000).

Homomeric TRPC4 or TRPC5 subunits underlie currents with a unique doubly rectifying current-voltage relationship with single-channel conductance of 28 and $38 \mathrm{pS}$, respectively. In addition, TRPC4 and TRPC5 channels are unique among TRP channels in that they are potentiated by micromolar concentrations of the trivalent cations $\mathrm{La}^{3+}$ or $\mathrm{Gd}^{3+}$ (Schaefer et al., 2000; Strübing et al., 2001). TRPC5 is dramatically potentiated by intracellular $\mathrm{Ca}^{2+}$, which does not seem to involve calmodulin (CaM). Intracellular $\mathrm{Ca}^{2+}$ also potentiates TRPC4 channel activity to a lesser degree (Blair et al., 2009). CaM itself was reported to accelerate TRPC5 agonist-activated current via a CaM-binding site located at the $\mathrm{C}$ terminus of TRPC5 but not the CaM/IP3Rbinding (CIRB) domain (Ordaz et al., 2005). Other modulations include potentiation of TRPC5 channels by extracellular thioredoxin (Xu et al., 2008) and nitric oxide (Yoshida et al., 2006), inhibition of TRPC4 channels by $\mathrm{PIP}_{2}$ (Otsuguro et al., 2008), inhibition of outward TRPC5 current by intracellular $\mathrm{Mg}^{2+}$ (Obukhov and Nowycky, 2008), and desensitization of TRPC5 channels by PKC-mediated phosphorylation (Ordaz et al., 2005).

In heterologous expression systems, homomeric TRPC5 channels can be rapidly delivered to the plasma membrane after stimulation of growth factor receptors via Rac, phosphatidylinositol 3 kinase, and phosphatidylinositol 5 kinase (Bezzerides et al., 2004). In young hippocampal neurons, TRPC5 channel subunits seem to interact with growth cone-enriched protein stathmin 2 , are packaged into vesicles, and then carried to newly formed growth cones, where TRPC5 expression modulates neurite extension and growth cone morphology (Greka et al.,
2003). A recent study showed that the downstream signaling for TRPC5 in neurite growth and axon formation may involve CaM kinase kinase and CaM kinase I $\gamma$ (Davare et al., 2009).

TRPC1, TRPC4, and TRPC5 are expressed in the brain, predominantly in the hippocampus, cortex, olfactory bulb, and amygdala as well as heart, lung, liver, spleen, and testis (Venkatachalam and Montell, 2007; Riccio et al., 2009). TRPC1 was reported to mediate store-operated current (Zitt et al., 1996), stretch-activated current (Maroto et al., 2005), or the metabotropic glutamate receptor 1 (mGluR1)-evoked slow EPSC (Kim et al., 2003). One group reported that TRPC1(-/-) mice have increased body size, and the store-operated current was not affected in vascular smooth muscle cells from the knockout mice (Dietrich et al., 2007), whereas another group reported that TRPC1 $(-/-)$ mice exhibit impaired salivary gland fluid secretion while the storeoperated current was reduced (Liu et al., 2007). A recent study found that TRPC1(-/-) mice displayed normal mGluR1-mediated synaptic transmission, with no obvious impairment of slow EPSCs or store-operated current (Hartmann et al., 2008). These conclusions depend on one TRPC1(-/-) mouse, and further studies should be carried out to verify that the mice indeed lack TRPC1 protein. This issue is complicated by the lack of adequate TRPC1 antibodies.

TRPC4(-/-) mice are viable, fertile, and exhibit no gross abnormalities (Freichel et al., 2001). At the cellular level, TRPC4 plays an important role in $\mathrm{Ca}^{2+}$ signaling in endothelial cells, and TRPC4(-/-) mice have defects in acetylcholine-induced vasoregulation and lung microvascular permeability (Freichel et al., 2001; Tiruppathi et al., 2002). Another study using TRPC4(-/-) mice concluded that TRPC4 mediates the increase of 5-hydroxytryptamine 2 receptor-coupled GABA release in thalamic interneurons (Munsch et al., 2003). TRPC5(-/-) mice exhibit no obvious developmental or anatomical defects. However, upon behavioral testing, TRPC5(-/-) mice exhibit a reduced anxiety-like (innate fear) phenotype (Riccio et al., 2009). The cellular mechanism underlying this phenotype stems from reduced responses mediated by group $1 \mathrm{mGluR}$ and cholecystokinin 2 receptors in neurons of the amygdala, a brain region that integrates sensory input with behaviors related to fear and other emotions (Riccio et al., 2009). It is noteworthy that mice lacking stathmin, a protein interacting with TRPC5, have a similar phenotype (Shumyatsky et al., 2005).

\section{B. Transient Receptor Potential C3/C6/C7 Subgroup}

TRPC3, TRPC6, and TRPC7 amino acid sequences are roughly $75 \%$ identical. When expressed in heterologous systems, these proteins are potentiated by $\mathrm{G}_{\mathrm{q} / 11^{-}}$-coupled receptors or by direct application of diacylglycerol (DAG) analogs (Hofmann et al., 1999; Okada et al., 1999). TRPC3/C6/C7 channels generate nonselective, doubly rectifying cation currents with a single-channel conductance of 65,35 , and $25 \mathrm{pS}$, respectively. They have 
relatively low selectivity for $\mathrm{Ca}^{2+}$ over $\mathrm{Na}^{+}$and are sensitive to intracellular $\mathrm{Ca}^{2+}$. TRPC3 may assemble with TRPC1 in some cells (Lintschinger et al., 2000; Strübing et al., 2003).

Several signaling molecules modulate TRPC3, TRPC6, and TRPC7 channel activities. DAG analogs potentiate TRPC3/C6/C7 channel activity but not via DAG's stimulation of PKC (Trebak et al., 2003). By phosphorylating Ser-712 in TRPC3, PKC itself negatively regulates TRPC3 function (Venkatachalam et al., 2003; Trebak et al., 2005). PKG directly phosphorylates TRPC3 and inhibits the channel activity (Kwan et al., 2004). The nonreceptor tyrosine kinases $S r c$ and Fyn positively regulate TRPC3 and TRPC6, respectively (Hisatsune et al., 2004; Vazquez et al., 2004). Intracellular $\mathrm{Ca}^{2+}$ stimulates TRPC6 but inhibits TRPC7 activity (Shi et al., 2004). TRPC3 reportedly interacts with syntaxin 3 , which may be involved in channel trafficking or insertion (Singh et al., 2004). Translocation of TRPC3 may also be regulated by its interaction with the scaffolding protein Homer1 (Kim et al., 2006). TRPC3 was further found to associate via its $\mathrm{N}$ terminus with $\mathrm{PLC} \gamma 1$ to form a bimolecular $\mathrm{PH}$ domain, which binds $\mathrm{PIP}_{2}$ as well as sphingosine-1-phosphate (van Rossum et al., 2005). Thus, TRPC3/C6/C7 channels may serve as versatile downstream effectors for a wide range of hormone and neurotransmitter receptors.

TRPC3 is present in brain, with the highest expression in cerebellum, cortex, and hippocampus. In hippocampal neurons and pontine neurons, TRPC3 is reportedly activated through a pathway that is initiated by binding of brain-derived neurotrophic factor to $\operatorname{TrkB}$, engagement of a $\operatorname{PLC} \gamma$, and activation of the inositol trisphosphate receptor (Li et al., 1999; Amaral and Pozzo-Miller, 2007), whereas in striatal cholinergic neurons or cerebellar Purkinje neurons, mGluR1s activate TRPC3 (Berg et al., 2007; Hartmann et al., 2008). TRPC3 is also reportedly involved in brain-derived neurotrophic factor-induced axon guidance or neuronal survival in cerebellar granule cells (Li et al., 2005; Jia et al., 2007). Brain development in TRPC3(-/-) mice appears grossly normal. However, TRPC3(-/-) mice (but not TRPC1-TRPC4 double-knockout mice) lack mGluR1-mediated inward currents or slow synaptic potentials (Hartmann et al., 2008), suggesting that TRPC3 is responsible for the mGluR-evoked slow EPSCs in mouse cerebellar Purkinje cells. More importantly, a defect in walking behavior was found in TRPC3(-l-) mice, indicating a critical function for TRPC3 in motor coordination (Hartmann et al., 2008). Subsequently, "moonwalker" mice, which have motor and coordination defects with a characteristic backward walk, were shown to have a gain-of-function mutation (T635A) in TRPC3 (Becker et al., 2009). Gain of function resulting in constitutive activation of TRPC3 channels overloads cells with $\mathrm{Ca}^{2+}$. It is interesting that TRPC3 loss of function and gain of function have similar phenotypes (Trebak, 2010). Transgenic mice with cardiac-specific overexpression of TRPC3 display a cardiomyopathic phenotype with increased hypertrophy after pressure overload (Nakayama et al., 2006).

TRPC6 channels are abundant in smooth and cardiac muscle cells and thus are candidates for the receptoractivated nonselective cation channels long known to exist in these cells. TRPC6 is an essential part of the $\alpha 1$-adrenoreceptor-activated cation channel in rabbit portal vein myocytes (Inoue et al., 2001). As reported for numerous $\mathrm{Ca}^{2+}$ channels with constitutive activity, cardiac-specific overexpression of TRPC6 in transgenic mice results in cardiomyopathy (Kuwahara et al., 2006). Thus, it is important to find conditions in which TRPC6 is overexpressed or contains gain-of-function mutations. Indeed, gain-of-function mutations in TRPC6 are associated with the kidney disorder focal segmental glomerulosclerosis, characterized by proteinuria, nephrotic syndrome, and progressive loss of renal function in humans (Reiser et al., 2005; Winn et al., 2005). It would seem that this gain of function results in loss of normal podocyte function.

TRPC6(-/-) mice exhibit agonist-induced contractility of cerebral arteries, perhaps as a result of compensatory up-regulation of TRPC3 and TRPC7 (Dietrich et al., 2005). TRPC6 is reported to affect dendritic growth, synaptic formation, and neuronal survival ( $\mathrm{Li}$ et al., 2005; Jia et al., 2007; Zhou et al., 2008); however, brain development appears normal in TRPC6(-/-) mice. Transgenic mice overexpressing TRPC 6 in the forebrain show enhanced spatial learning and memory (Zhou et al., 2008).

TRPC7 is widely expressed. In brain, TRPC7 may couple to the activation of group $1 \mathrm{mGluR}$ in cholinergic neurons of the striatum (Berg et al., 2007). In heart, angiotensin II may activate TRPC7 to produce $\mathrm{Ca}^{2+}$ overload, induce myocardial apoptosis, and contribute to heart failure (Satoh et al., 2007).

\section{Transient Receptor Potential C2 Subgroup}

TrpC2 is a pseudogene in humans, but its rodent ortholog encodes a functional TRPC2 channel important to pheromone sensing. In heterologous expression, TRPC2 forms homomeric channels permeant to cations and is potentiated by PLC-mediated signaling cascades (Vannier et al., 1999; Hofmann et al., 2000). In mouse, TRPC2 is predominantly expressed in the vomeronasal organ, a specialized region of the vertebrate brain involved in pheromone sensing (Liman et al., 1999; Vannier et al., 1999). In vomeronasal sensory neurons, DAG can directly activate TRPC2 (Lucas et al., 2003). Assumed homomeric TRPC2 current-voltage relationships are linear with a single channel conductance of $42 \mathrm{pS}$ (Lucas et al., 2003).

The selective expression of TRPC2 in the vomeronasal organ hints at its potential role in pheromone signaling 
and sexual responses. Indeed, TRPC2(-/-) mice display radically altered response to pheromone cues and abnormal mating behavior (Leypold et al., 2002; Stowers et al., 2002). TRPC2(-/-) male mice fail to display malemale aggression, and they initiate sexual and courtship behaviors toward both male and female mice. TRPC2(-/-) female mice show a reduction in femalespecific behavior but display unique characteristics of male sexual and courtship behaviors (Stowers et al., 2002; Kimchi et al., 2007). TRPC2 protein was detected in spermatogenic cells based on antibody staining (Wissenbach et al., 1998; Jungnickel et al., 2001), but TRPC2(-/-) mouse fertility is normal.

\section{The Transient Receptor Potential (Vanilloid) Family}

The TRPV (vanilloid) subfamily (Fig. 2) is named after vanilloid receptor 1 (Caterina et al., 1997). Six mammalian TRPV proteins (TRPV1-6) have been identified. They are commonly divided into two subgroups based on sequence homology, functional similarities, and $\mathrm{Ca}^{2+}$ selectivity: TRPV1-V4 and TRPV5/V6. The channel structure of the TRPV family contains intracellular Nterminal ankyrin repeats, prevalent protein interaction motifs that have been suggested to promote channel tetramerization (Erler et al., 2004) and regulate channel activity (Al-Ansary et al., 2010; Phelps et al., 2010). The pharmacology of the TRPV family has been detailed in a recent review (Vriens et al., 2009).

\section{A. Transient Receptor Potential V1-V4 Subgroup}

TRPV1-V4 subgroup members are weakly $\mathrm{Ca}^{2+}$-selective cation channels modulated by various intracellular signals, including $\mathrm{Ca}^{2+}$, CaM, and phosphoinositides (Zhu, 2005; Rohacs and Nilius, 2007). As for several members of the TRP superfamily and certain other ion channels (e.g., Hv1 and K2P), channels in this subgroup exhibit high temperature sensitivities $\left(Q_{10}>10\right)$, suggesting roles for TRPVs in thermal sensing by peripheral sensory neurons and other tissues. However, these channels are modulated by many different types of chemical and physical stimuli, indicating more complex roles in cellular sensing besides thermal sensing.

TRPV1 forms a voltage-gated outwardly rectifying weakly $\mathrm{Ca}^{2+}$-selective cation channel activated by noxious heat $\left(>43^{\circ} \mathrm{C}\right)$ and low $\mathrm{pH}$ (Caterina et al., 1997; Tominaga et al., 1998; Jordt et al., 2000). As its name suggests, TRPV1 can also be activated by vanilloid compounds, such as capsaicin and capsinate found in hot (chili) and nonpungent (bell) peppers, respectively (Caterina et al., 1997; Iida et al., 2003), as well as by a myriad of endogenous compounds, such as anandamide ( $N$-arachidonoylethanolamine) (Zygmunt et al., 1999), $\mathrm{N}$-arachidonoyldopamine (Huang et al., 2002), $N$-oleoyldopamine (Chu et al., 2003), and arachidonic acid metabolites (12- and 15-hydroperoxyeicosatetraenoic acid, 5- and 15-hydroxyeicosatetraenoic acid) (Hwang et al., 2000). However, because of their lipophilicity, many of these second messengers may have broad effects on most ion channels. Many accumulate in plasma membranes but are also rapidly altered, making it difficult to test their activities under physiological conditions. A recent study found a peptide toxin, DkTx, from the Earth Tiger tarantula (Ornithoctonus huwena) that selectively and irreversibly activates TRPV1 (Bohlen et al., 2010). The toxin has a unique tandem repeat structure that binds to trap TRPV1 in the open state by interacting with residues in pore-forming region of the channel.

The activity of TRPV1 is modulated by a variety of intracellular molecules, including CaM, ATP, PIP ${ }_{2}$, and $\mathrm{Ca}^{2+}$-dependent phosphorylation and dephosphorylation. CaM interacts with both the $\mathrm{C}$ and $\mathrm{N}$ termini of the channel and cross-links them to desensitization (Numazaki et al., 2003; Rosenbaum et al.,



FIG. 2. TRPV (vanilloid) family. A, molecular domains of TRPV channels and their current-voltage relationships. The ankyrin repeat is an $\sim 33$-residue motif consisting of two $\alpha$ helices separated by loops. This region in TRPV1 binds ATP. B, results of genetic deletion experiments. 
2004; Lishko et al., 2007). Intracellular ATP competes with CaM for binding at overlapping sites in the TRPV1 ankyrin repeat domain, thereby opposing the actions of CaM and enhancing TRPV1 currents, and prevents desensitization (Lishko et al., 2007). Although the effect of $\mathrm{PIP}_{2}$ on TRPV1 modulation has been controversial, there is growing support that $\mathrm{PIP}_{2}$ sensitizes TRPV1. PIP ${ }_{2}$ binds the TRPV1 $\mathrm{C}$ terminus and competes with CaM for binding (Kwon et al., 2007). $\mathrm{PIP}_{2}$-mediated enhancement of TRPV1 current was also reported to require $\mathrm{PIP}_{2}$ binding to PIRT (phosphoinositide-interacting regulator of TRP), a putative auxiliary subunit of the channel (Kim et al., 2008a). TRPV1 activity is also regulated through the dynamic balance of $\mathrm{Ca}^{2+}$-dependent phosphorylation and dephosphorylation. Activation of the protein phosphatase calcineurin dephosphorylates the channel and enables channel desensitization (Docherty et al., 1996), whereas activation of protein kinase C (Premkumar and Ahern, 2000) and protein kinase A (De Petrocellis et al., 2001) seems to increase channel activity.

TRPV1 is highly expressed in myelinated $(\mathrm{A} \delta)$ and unmyelinated (C) nociceptive fibers of dorsal root, trigeminal, and nodose ganglion neurons (Helliwell et al., 1998; Caterina et al., 2000). Although there is a paucity of functional evidence for TRPV1 in the central nervous system, TRPV1 may be present in the brain (Steenland et al., 2006) and was proposed to play a role in synaptic plasticity, such as long-term depression (Gibson et al., 2008; Maione et al., 2009). TRPV1 is reportedly expressed in other tissues; like most of the TRP field, however, functional evidence lags behind error-prone antibody-determined localization data. Because TRPV1 is activated by heat and expressed in thermosensitive tissues, there is much interest in whether TRPV1 is important for thermosensation. Indeed, TRPV1(-/-) mice display reduced thermal hyperalgesia after inflammation and injury; however, whether TRPV1(-/-) mice have decreased responses to acute noxious heat is still debated (Caterina et al., 2000; Davis et al., 2000; Bölcskei et al., 2005). Many of the pro-inflammatory agents produced during injury reduce TRPV1 thresholds to noxious stimuli to as low as $30^{\circ} \mathrm{C}$, so that normally nonpainful thermal stimuli are capable of activating TRPV1 (Sugiura et al., 2002). As such, TRPV1(-/-) mice show reduced thermal hyperalgesia in response to inflammatory mediators such as bradykinin or NGF (Caterina et al., 2000; Davis et al., 2000; Chuang et al., 2001). Drugs developed to antagonize TRPV1 by the pharmaceutical industry reduce sensitivity to heat stimuli in humans and initially raise body temperature (Gavva et al., 2008). This may be due to the tonic activation of visceral TRPV1 by nonthermal factors, which suppresses autonomic cold-defense effectors and body temperature; blockade of the activation by TRPV1 antagonists disinhibits thermoeffectors and causes hyper- thermia (Romanovsky et al., 2009). In addition to important roles in thermosensation and thermoregulation, TRPV1 has been reported to be important for normal bladder function (Birder et al., 2002), gastrointestinal motility (Rong et al., 2004), behavioral responses to ethanol (Blednov and Harris, 2009; Ellingson et al., 2009), airway inflammation and disease (Geppetti et al., 2006), and detection of salt (Lyall et al., 2004).

TRPV2 is $50 \%$ identical to TRPV1 and forms a weakly $\mathrm{Ca}^{2+}$-selective cation channel. It is activated by temperatures $>52^{\circ} \mathrm{C}$ when expressed in Xenopus laevis oocytes (Caterina et al., 1999; Kanzaki et al., 1999). There are, however, species-dependent differences in this activation, and human TRPV2 is apparently not activated by heat (Neeper et al., 2007). TRPV2 is reported to be present in a wide variety of tissues, including brain, pancreas, spleen, lung, stomach, intestine, bladder, prostate, and blood cells (Caterina et al., 1999; Kowase et al., 2002), with the usual caveat that antibody specificity has not been tested in knockout mice. It has been proposed that TRPV2 may serve as an endosomal calcium release channel that controls endosome fusion and/or exocytosis (Saito et al., 2007). Indeed, many studies suggest that activation of TRPV2 causes translocation of the channel to the plasma membrane (Kanzaki et al., 1999; Iwata et al., 2003; Nagasawa et al., 2007; Hisanaga et al., 2009), and TRPV2 inhibitor transilast ( $N-(3,4-$ dimethoxycinnamoyl) anthranilic acid) prevents this redistribution (Hisanaga et al., 2009). It is noteworthy that aberrant localization of TRPV2 is detected in rodent models of muscular dystrophy, and expression of dominant-negative TRPV2 reduced muscle damage (Iwata et al., 2009). TRPV2 has been shown to be expressed in macrophages and has a critical role in macrophage particle binding and phagocytosis. TRPV2(-/-) mice have been consistently shown to be more vulnerable when challenged with pathogens such as Listeria monocytogenes, mainly because of the greater organ bacterial load (Link et al., 2010).

TRPV3 also forms a voltage-sensitive weakly $\mathrm{Ca}^{2+}$ selective cation channel that is activated by warm temperatures $\left(33-39^{\circ} \mathrm{C}\right)$ (Peier et al., 2002b; Smith et al., 2002; Xu et al., 2002) and a variety of botanical compounds including camphor, eugenol, thymol, and carvacrol (Moqrich et al., 2005; Xu et al., 2006). TRPV3 currents are unusual in two respects; they sensitize (grow larger) with repeated activation, and their temperaturedependent potentiation exhibits a marked hysteresis. In rodent skin keratinocytes, TRPV3 is proposed to sense warmth (Peier et al., 2002b; Chung et al., 2004); TRPV3(-/-) mice display altered behavioral responses to heat, including altered temperature preferences in thermotaxis assays (Moqrich et al., 2005). Unexpectedly, a recent study found that TRPV3 is required for epidermal growth factor receptor signaling in keratinocytes, 
and TRPV3(-/-) mice exhibit wavy hair coat and curly whiskers (Cheng et al., 2010a).

Many pro-inflammatory agents such as bradykinin, histamine, ATP, and prostaglandin E2 sensitize TRPV3 function (Xu et al., 2006; Huang et al., 2008; Mandadi et al., 2009). ATP interacts with the channel's N-terminal ankyrin repeats to regulate this sensitization (Phelps et al., 2010). Elevated TRPV3 activity can dramatically influence skin integrity; rodents with constitutively active TRPV3 channels have an increased susceptibility to dermatitis and skin lesions (Asakawa et al., 2006; Imura et al., 2007).

TRPV4 is activated by warm temperatures in the range of $27-34^{\circ} \mathrm{C}$; consequently, at physiological temperatures, the channel should demonstrate significant constitutive activity (Liedtke et al., 2000; Güler et al., 2002; Watanabe et al., 2002). Activation of TRPV4 by heat may not be direct; in inside-out patches, TRPV4 cannot be activated by heat, yet it can still be activated by $4 \alpha$-phorbol 12,13 didecanoate, a non-PKC-activating phorbol ester (Watanabe et al., 2002). TRPV4 is sensitive to osmotic and mechanical stimuli, such as cell swelling or fluid flow, and sensitivity of TRPV4 to these stimuli may depend on phospholipase $A_{2}$ activation and the subsequent production of the arachidonic acid metabolite epoxyeicosatrienoic acid (EET) (Liedtke et al., 2000; Strotmann et al., 2000; Watanabe et al., 2003; Vriens et al., 2004, 2005; Fernandes et al., 2008). TRPV4 can also be activated by botanical and synthetic compounds such as $4 \alpha$-phorbol-12,13-dihexanoate (Klausen et al., 2009), bisandrographolide (Smith et al., 2006), and ( $N-((1 S)-1-\{[4-((2 S)-2-\{[(2,4-$ dichlorophenyl)sulfonyl]amino\}-3-hydroxypropanoyl)-1-piperazinyl]carbonyl\}-3-methylbutyl)-1-benzothiophene-2-carboxamide (GSK1016790A) (Thorneloe et al., 2008). Like TRPV1, TRPV4 is modulated by CaM and ATP, C-terminal CaM binding potentiating the current (Strotmann et al., 2003) and $\mathrm{Ca}^{2+}$ - dependent $\mathrm{CaM}$ binding to the $\mathrm{N}$ terminus desensitizing the current (Rosenbaum et al., 2004; Lishko et al., 2007). A variety of kinases also seem to modulate its activity (Gao et al., 2003; Chen et al., 2008a; Fan et al., 2009; Wegierski et al., 2009).

TRPV4 is widely distributed and was proposed to sense temperature in the hypothalamus, skin and primary sensory neurons (Liedtke et al., 2000; Güler et al., 2002; Peier et al., 2002b). However, three groups reported TRPV4(-/-) mice had normal behavioral responses to thermal stimulation in the hot plate and radiant paw heating assays, except under inflammatory conditions (Liedtke and Friedman, 2003; Suzuki et al., 2003; Todaka et al., 2004). A more recent study revealed that TRPV4(-/-) mice exhibited a strong preference for $34^{\circ} \mathrm{C}$, whereas wild-type mice failed to discriminate between floor temperatures of $30^{\circ} \mathrm{C}$ and $34^{\circ} \mathrm{C}$ (Lee et al., 2005a). Such differences in findings may be due to strain differences.

The sensitivity of TRPV4 to osmotic stimuli may be important for cellular and systemic osmoregulation.
TRPV4 was detected in putative osmoreceptive neurosensory cells around the ventricle (Liedtke et al., 2000), and TRPV4(-/-) mice display diminished drinking, elevated systemic osmotic pressure, and reduced synthesis of antidiuretic hormone in response to systemic hypertonicity induced by salt ingestion (Liedtke and Friedman, 2003). However, another study described an increase in antidiuretic hormone secretion in response to hypertonicity induced by water deprivation in TRPV4(-/-) mice (Mizuno et al., 2003). TRPV4 was also detected in cholangiocytes or the ciliated epithelial cells lining the bile duct, where it may play a key role in osmotic regulation of bile composition (Gradilone et al., 2007).

In support of a mechanosensing function for TRPV4, TRPV4(-/-) mice have a reduced behavioral response to persistent tail pressure as well as a reduced sensory neuronal discharge to pin prick on glabrous skin (Suzuki et al., 2003). TRPV4 may also contribute to the development of mechanical hyperalgesia after inflammation and injury (Alessandri-Haber et al., 2006). TRPV4 is expressed in urothelium and may play a role in urothelium-mediated transduction of intravesical mechanical pressure. In support of this hypothesis, TRPV4(-/-) mice display impaired bladder function (Birder et al., 2007; Gevaert et al., 2007). TRPV4 is expressed in inner and outer hair cells of the cochlea, but TRPV4(-/-) mice show no difference in the response to acoustic startle compared with wild-type mice (Liedtke and Friedman, 2003), indicating that the channel may not be the mechanotransduction channel in hair cells. In lung endothelial cells, TRPV4 may respond to unequal pressure across the alveolar septal barrier to regulate the permeability of these cells (Alvarez et al., 2006; Hamanaka et al., 2007). TRPV4(-/-) mice displayed significantly less lung edema in response to high peak inflation pressure ventilation compared with wild-type mice (Whitlock, 1995).

TRPV4 seems to regulate vascular tone (Earley et al., 2009; Zhang et al., 2009) and bone deposition and remodeling (Masuyama et al., 2008; Mizoguchi et al., 2008). It is noteworthy that mutations in TRPV4 have been identified in patients with three dominantly inherited skeletal phenotypes: autosomal-dominant brachyolmia, spondylometaphyseal dysplasia Kozlowski type, and metatropic dysplasia (Rock et al., 2008; Krakow et al., 2009). TRPV4 mutations have also been linked to patients with congenital distal spinomuscular atrophy, Charcot-Marie-Tooth disease type 2C, and scapuloperoneal spinal muscular atrophy (Auer-Grumbach et al., 2010; Deng et al., 2010; Landouré et al., 2010).

\section{B. Transient Receptor Potential V5/V6 Subgroup}

TRPV5 and TRPV6 are highly homologous proteins, sharing 74\% identity (Clapham, 2003). Like other TRPV family members, they form $\mathrm{Ca}^{2+}$-permeable inwardly rectifying cation channels; unlike other TRPV family 
members, however, they are highly $\mathrm{Ca}^{2+}$ selective $\left(\mathrm{P}_{\mathrm{Ca}}\right.$ ' $\mathrm{P}_{\mathrm{Na}}>100$ ) and are not heat-sensitive (Vennekens et al., 2000; Yue et al., 2001). Rather, they tend to be active at low $\mathrm{Ca}^{2+}$ concentrations and physiological membrane potentials. Both TRPV5 and TRPV6 inactivate to prevent $\mathrm{Ca}^{2+}$ overload, although with different kinetics (Suzuki et al., 2000; Hoenderop et al., 2001; Nilius et al., 2002). TRPV5 has a 100-fold higher affinity for the nonspecific blocker ruthenium red $\left(\mathrm{IC}_{50}, 121 \mathrm{nM}\right)$ than does TRPV6 $\left(\mathrm{IC}_{50}, 9 \mu \mathrm{M}\right)$ (Hoenderop et al., 2001; Voets et al., 2001).

The activity of TRPV5 and TRPV6 at the plasma membrane is regulated by a variety of second messengers, including $\mathrm{Ca}^{2+}, \mathrm{CaM}, \mathrm{Mg}^{2+}$, ATP, $\mathrm{PIP}_{2}$, and protein kinases. $\mathrm{Ca}^{2+}$ acts as a negative feedback regulator of channel activity and contributes to channel inactivation (Vennekens et al., 2000; Hoenderop et al., 2001; Nilius et al., 2001; Yue et al., 2001). CaM interacts with TRPV5 and TRPV6 in a $\mathrm{Ca}^{2+}$-dependent manner (Lambers et al., 2004) and was proposed to mediate the slow component of $\mathrm{Ca}^{2+}$-dependent inactivation (Niemeyer et al., 2001). Intracellular $\mathrm{Mg}^{2+}$ causes a fast voltage-dependent block as well as a slower inhibition of TRPV5 and TRPV6 current (Nilius et al., 2000; Voets et al., 2003; Lee et al., 2005b). ATP binding sites have been identified within the ankyrin repeat domain, and the $\mathrm{C}$ terminus of TRPV6 and intracellular ATP stabilizes TRPV5 and TRPV6 currents (Hoenderop et al., 2001; Al-Ansary et al., 2010). PIP $_{2}$ binding to the TRP box potentiates TRPV5 and TRPV6, and its depletion in the membrane via $\mathrm{Ca}^{2+}$-dependent activation of PLC contributes to channel inactivation (Rohács et al., 2005; Thyagarajan et al., 2008; Thyagarajan et al., 2009). A variety of other regulatory molecules may modulate its activity or membrane expression. $\mathrm{Ca}^{2+}$ binding proteins 80K-H/PRKCSH/hepatocystin and Calbindin- $\mathrm{D}_{28 \mathrm{~K}}$ tether to TRPV5 and prevent negative feedback of $\mathrm{Ca}^{2+}$ on the channels (Gkika et al., 2004; Lambers et al., 2006). Bbox and SPRY-domain containing protein interacts with TRPV5 and decreases channel activity (van de Graaf et al., 2006), whereas RGS2 (Schoeber et al., 2006) and Nipsnap1 (Schoeber et al., 2008) bind to TRPV6 and inhibit the channel's activity.

TRPV5 is expressed in a number of tissues. In the kidney, TRPV5 is predominantly expressed in the distal convoluted and connecting tubule where it is important for transcellular transport and active reabsorption of $\mathrm{Ca}^{2+}$ in the kidney (Hoenderop et al., 1999). Indeed, ablation of the TRPV5 results in impaired $\mathrm{Ca}^{2+}$ resorption in the distal convoluted and connecting tubule; TRPV5(-/-) mice excrete approximately six times more $\mathrm{Ca}^{2+}$ in their urine and display compensatory increases in vitamin $\mathrm{D}$ levels and intestinal hyperabsorption of $\mathrm{Ca}^{2+}$. In addition, they display polyuria with significantly more acidic urine than that of wild-type mice (Hoenderop et al., 2003). TRPV5(-/-) mice also display bone abnormalities, including reduced trabecular and cortical bone thickness (Hoen- derop et al., 2003) and increased osteoclast number and size (van der Eerden et al., 2005). Yet TRPV5(-/-) mice had low serum deoxypyridinoline levels, indicating decreased rate of bone breakdown and, unlike other mouse models with decreased osteoclast function, showed decreased bone thickness without osteopetrosis (van der Eerden et al., 2005).

TRPV6 is more widely distributed than TRPV5 (Peng et al., 2000; Hoenderop et al., 2001; Hirnet et al., 2003). In the intestine, TRPV6 localizes to the brush border membrane of enterocytes, where it is proposed to mediate transcellular $\mathrm{Ca}^{2+}$ entry (Peng et al., 1999; Zhuang et al., 2002). Indeed, TRPV6(-/-) mice that were fed a low $\mathrm{Ca}^{2+}$ diet exhibited decreased $\mathrm{Ca}^{2+}$ absorption and serum $\mathrm{Ca}^{2+}$ levels compared with wild-type mice; however, a disruption of closely adjacent EphB6 gene in the TRPV6(-/-) mice may complicate the interpretation of this phenotype (Bianco et al., 2007; Benn et al., 2008). In the kidney, TRPV6 is expressed in the convoluted tubules, connecting tubules, and cortical and medullary collecting ducts of the nephron, where it helps resorb $\mathrm{Ca}^{2+}(\mathrm{Ni}-$ jenhuis et al., 2003). In the placental trophoblast, TRPV6 contributes to the transfer of $\mathrm{Ca}^{2+}$ from mother to fetus (Moreau et al., 2002; Suzuki et al., 2008 ) and may contribute to the reduced litter size of TRPV6(-/-) mice (Bianco et al., 2007).

\section{The Transient Receptor Potential (Melastatin) Family}

The mammalian TRPM subfamily has eight members (Fig. 3) and is divided into three main groups based on similarities in amino acid sequence: TRPM1/ M3, TRPM4/M5, and TRPM6/M7; TRPM2 and TRPM8 exhibit low sequence homology and therefore do not seem to warrant grouping. TRPM proteins have a TRP domain C-terminal to the transmembrane segments but lack ankyrin repeats in the $\mathrm{N}$ terminus. The $\mathrm{N}$ terminal part of TRPM proteins is considerably longer than the corresponding regions in TRPC and TRPV members. The $\mathrm{N}$ terminus contains a large TRPM homology region (around 700 amino acids), which bears no homology to other known molecules. The biological significance of this region is still unknown. The $\mathrm{C}$ terminus can be divided into two regions, a coiled-coil domain and a second variable region. TRPM2, TRPM6, and TRPM7 are unique among known ion channels in that they encode enzymatically active protein domains in their $\mathrm{C}$ termini.

\section{A. Transient Receptor Potential M1/M3 Subgroup}

TRPM1, the founding member of the TRPM subfamily, was discovered in a melanoma screen as a transcript that had decreased expression in highly metastatic, compared with less metastatic melanoma cells (Duncan et al., 1998). A recent analysis of mRNA 


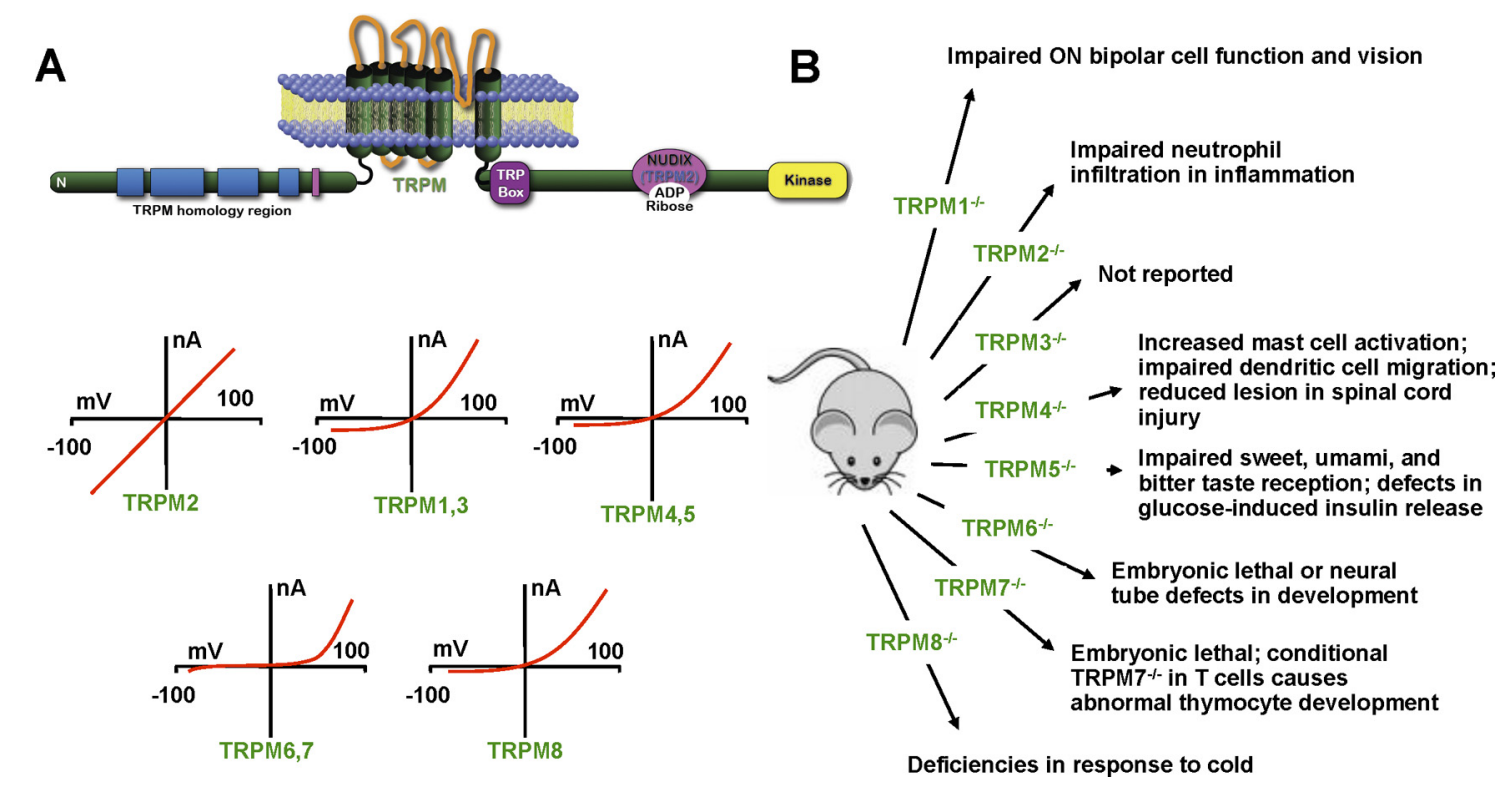

FIG. 3. TRPM (melastatin) family. A, molecular domains of TRPM channels and their current-voltage relationships. NUDIX is a phosphohydrolase family homologous region in TRPM2 that binds ADP ribose. TRM6 and TRPM7 possess a C-terminal serine/threonine kinase that is similar in structure to protein kinase A. B, results of genetic deletion experiments.

showed that at least five human ion-channel-forming isoforms of TRPM1 could be detected in melanocytes, melanoma, brain, and retina (Oancea et al., 2009). In melanoma cells, TRPM1 is prevalent in highly dynamic intracellular vesicular structures. Total internal reflection fluorescent imaging of HEK cells expressing the GFP-TRPM1 splice variants suggests that the GFP-tagged isoforms did not reach the plasma membrane (Oancea et al., 2009). When expressed in SK-Mel22a melanoma cells, TRPM1 channels show a nonselective, outwardly rectifying current, which suggests that TRPM1 function as plasma membrane channels might depend on melanocytespecific trafficking. Intriguingly, TRPM1 expression correlates with melanin content in neonatal human epidermal melanocytes, but how TRPM1 might regulate melanin is not known (Oancea et al., 2009).

Several independent studies have found that TRPM1 has a critical role in synaptic function in ON bipolar cells in the retina. Mutations in TRPM1 may contribute to congenital stationary night blindness (CSNB), a nonprogressive dark-adapted visual deficit (Morgans et al., 2009; Shen et al., 2009; Koike et al., 2010). TRPM1 is activated by the mGluR6 signaling cascade and thus is required for the depolarizing light response in ON bipolar cells. Consistent with the phenotype found in CSNBaffected humans, TRPM1(-l-) mice lack the b-wave normally recorded in electroretinograms. (Morgans et al., 2009; Shen et al., 2009; Koike et al., 2010). Additional support for TRPM1 in retinal function stems from human genetic studies by three independent groups, which showed that mutations in TRPM1 are associated with CSNB (Audo et al., 2009; Li et al., 2009; van Genderen et al., 2009).
TRPM3 is most closely related to TRPM1. TRPM3 forms a constitutively active, $\mathrm{Ca}^{2+}$-permeable, nonselective cation channel with a reported near linear current-voltage relationship in heterologous expression systems (Grimm et al., 2003). TRPM3 is alternatively spliced; TRPM $3 \alpha 1$ and TRPM $3 \alpha 2$, which differ only in the presumed pore region, show significant differences in their channel properties (Oberwinkler et al., 2005): TRPM $3 \alpha 1$ channels are poorly permeable to divalent cations, whereas TRPM $3 \alpha 2$ channels conduct $\mathrm{Ca}^{2+}$ and $\mathrm{Mg}^{2+}$. In addition, extracellular $\mathrm{Na}^{+}$ inhibits TRPM $3 \alpha 2$ but not TRPM $3 \alpha 1$ channels. Both variants exhibit constitutively active, outwardly rectifying currents that are blocked by intracellular $\mathrm{Mg}^{2+}$, similar to TRPM6 and TRPM7 channels. Another short variant, TRPM $3_{1325}$ (shorter carboxyl terminus), mediates a spontaneous, nonselective cation current with $\mathrm{P}_{\mathrm{Ca}} / \mathrm{P}_{\mathrm{Na}}=1.6$ and detectable $\mathrm{Mg}^{2+}$ permeability. The single-channel conductance of TRPM $3_{1325}$ is $\sim 80$ and $65 \mathrm{pS}$ in the presence of extracellular $\mathrm{Na}^{+}$and $\mathrm{Ca}^{2+}$, respectively. Their activities could be suppressed by $100 \mu \mathrm{M} \mathrm{Gd}^{3+}$ and $\mathrm{La}^{3+}$ and increased by hypotonicity or D-erythro-sphingosine, a metabolite of cellular sphingolipids (Grimm et al., 2003, 2005).

TRPM3 is most prominent in kidney, brain, and pituitary. However, the function of TRPM3 is poorly characterized, probably because of the existence of multiple variants with different properties. A TRPM3(-/-) mouse has not been reported to date. A recent report suggests that the steroid hormone pregnenolone sulfate can act as endogenous ligand for TRPM3 (Wagner et al., 2008). TRPM3 protein is expressed in pancreatic $\beta$ cells, and pregnenolone could augment glucose- 
induced insulin secretion from pancreatic islets by activating TRPM3 (Wagner et al., 2008). Highresolution oligonucleotide arrays were used to suggest that TrpM3 is a candidate gene for the Kabuki syndrome, a congenital mental retardation syndrome (Kuniba et al., 2009).

\section{B. Transient Receptor Potential M2}

TRPM2 contains a C-terminal nudix hydrolase domain that is highly homologous to the ADP pyrophosphatase NUDT9. This domain binds ADP ribose $\left(\mathrm{EC}_{50}\right.$, $\sim 100 \mu \mathrm{M})$ in a cleft in the NUDT9 domain of TRPM2 (Perraud et al., 2005) and hydrolyzes it (Perraud et al., 2001; Sano et al., 2001). ADP ribose arises from breakdown of $\beta$-NAD, CD38, or other enzymes acting on cyclic ADP ribose and hydrolysis of ADP polymers by polyADP ribose glycohydrolase. TRPM2 is also activated by oxidative or nitrosative stress (e.g., $\mathrm{H}_{2} \mathrm{O}_{2}$ ) (Hara et al., 2002), perhaps mediated by mitochondrial ADP-ribose (Perraud et al., 2005). High levels of intracellular $\mathrm{Ca}^{2+}$ have been proposed to activate TRPM2 $(>10 \mu \mathrm{M})(\mathrm{Kraft}$ and Harteneck, 2005; Du et al., 2009).

TRPM2 is a nonselective cation channel with a nearlinear current-voltage relationship and has a singlechannel conductance of $\sim 62 \mathrm{pS}$. TRPM2 current was insensitive to $100 \mu \mathrm{M} \mathrm{La}^{3+}$ but was inhibited by nonspecific channel blockers such as flufenamic acid or the antifungal agents clotrimazole or econazole (Hill et al., 2004). It is noteworthy that TRPM2 may function as a lysosomal $\mathrm{Ca}^{2+}$-release channel activated by intracellular ADP-ribose in addition to its role as a plasma membrane channel (Lange et al., 2009).

TRPM2 is highly expressed in cells of monocytic lineage. Because TRPM2 is regulated by signaling pathways responsive to oxidative stress and tumor necrosis factor- $\alpha$, it has been assumed to be a sensor for intracellular oxidation (Hara et al., 2002; Kaneko et al., 2006). TRPM2 is proposed to function in monocyte chemotaxis, which is known to be regulated by ADP-ribose (Massullo et al., 2006). Functional TRPM2 has been reported in neurons, where it may be involved in $\mathrm{H}_{2} \mathrm{O}_{2}$-induced neuronal death (Kaneko et al., 2006; Olah et al., 2009), and in pancreatic $\beta$ cells, where it may regulate insulin secretion (Togashi et al., 2006). Studies using TRPM2(-/-) mice suggest that the channel controls reactive oxygen speciesinduced chemokine production in monocytes and neutrophil infiltration in a mouse model of inflammation (Yamamoto et al., 2008). Human genetics studies indicate the potential involvement of TRPM2 in bipolar disorders (McQuillin et al., 2006). In addition, an inactivating proline-to-leucine substitution at position 1018 in TRPM2 is found in two related neurodegenerative disorders, amyotrophic lateral sclerosis and Parkinsonism/dementia complex, that have a high in- cidence on the Pacific Islands of Guam and Rota (Hermosura et al., 2008).

\section{Transient Receptor Potential M4/M5 Subgroup}

TRPM4 and TRPM5 are the only monovalent-selective ion channels of the TRP family (Launay et al., 2002; Hofmann et al., 2003; Liu and Liman, 2003; Prawitt et al., 2003). TRPM4 and TRPM5 have $\sim 40 \%$ sequence identity and exhibit similar channel properties. TRPM4 is expressed as two splice variants, TRPM4a (nonfunctional channel) and TRPM4b (functional channel) (Xu et al., 2001; Launay et al., 2002; Nilius et al., 2003). Both TRPM4b and TRPM5 channels have a single-channel conductance of $\sim 25 \mathrm{pS}$, their whole-cell currents are strongly outwardly rectified (Launay et al., 2002), and they are blocked by intracellular flufenamic acid and spermine (Ullrich et al., 2005). A short stretch of six acidic amino acids in the pore loop determines their monovalent selectivity (Nilius et al., 2003). Both are activated by relatively high $\mathrm{Ca}^{2+}$ levels in the cytosol ( $\sim 500$ and $80 \mu \mathrm{M}$ for TRPM4 and TRPM5, respectively) (Hofmann et al., 2003; Liu and Liman, 2003; Ullrich et al., 2005), and $\mathrm{PIP}_{2}$ reverses their $\mathrm{Ca}^{2+}$-dependent desensitization (Zhang et al., 2005; Nilius et al., 2006). Both TRPM4 and TRPM5 have been proposed to be preferentially sensitive to temperature in the range of 15 to $35^{\circ} \mathrm{C}$ (Talavera et al., 2005). TRPM4, but not TRPM5, is inhibited by intracellular ATP, whereas TRPM5 is inhibited by intracellular acidic $\mathrm{pH}$ (Nilius et al., 2004; Liu et al., 2005). TRPM5 activates and inactivates more rapidly than TRPM4. TRPM4 is also modulated by protein kinase $\mathrm{C}$ (PKC) phosphorylation, which enhances its sensitivity to intracellular $\mathrm{Ca}^{2+}$ (Nilius et al., 2005).

TRPM4 and TRPM5 probably underlie the often observed $\mathrm{Ca}^{2+}$-activated monovalent-selective cation current, and thus have attracted interest for their possible involvement in membrane potential oscillations (Launay et al., 2002; Prawitt et al., 2003). TRPM4 is ubiquitous, with highest expression in kidney and brain. Knockdown of TRPM4 decreases cerebral artery myogenic constrictions and thus may contribute to cerebral blood flow regulation (Reading and Brayden, 2007). Gain-of-function mutation of TRPM4 (E7K) causes impaired endocytosis and may be associated with human progressive familial heart block type 1 (Kruse et al., 2009). TRPM4(-/-) mice exhibit increased IgE-dependent mast cell activation and anaphylactic responses (Vennekens et al., 2007). Moreover, chemokine-dependent dendritic cell migration is considerably impaired in TRPM4(-/-) mice (Barbet et al., 2008). In a spinal cord injury model, TRPM4(-/-) mice were relatively protected compared with wild-type mice, and their neurological function improved more readily after injury (Gerzanich et al., 2009).

TRPM5 is expressed in taste receptor cells (Pérez et al., 2002), and sweet, umami, and bitter taste reception were 
reportedly abolished in TRPM5(-/-) mice, whereas sour or salty taste sensation was preserved (Zhang et al., 2003). The G protein PLC $\beta 2$-coupled receptors T1R and T2R may activate TRPM5 to produce these sensations (Zhang et al., 2003). Another group found markedly impaired but not complete absence of responses to bitter, sweet, and umami compounds (Damak et al., 2006). TRPM5 is expressed in pancreatic $\beta$-cells, where it may affect insulin release through PLC-dependent pathways (Gilon and Henquin, 2001). Indeed, recent studies from independent groups found defective glucose-induced insulin release in TRPM5(-/-) mice (Brixel et al., 2010; Colsoul et al., 2010). TRPM5 immunoreactivity was also seen in other chemosensory organs-the main olfactory epithelium and the vomeronasal organ, hinting at its potential functions in chemosensation (Kaske et al., 2007). Using TRPM5-GFP transgenic and TRPM5(-/-) mice, a recent study showed that TRPM5 is expressed in solitary enteroendocrine chemosensory cells in mouse duodenum and may be essential for the release of the endogenous opioids $\beta$-endorphin and Met-enkephalin and the release of uroguanylin from these cells (Kokrashvili et al., 2009b). It is noteworthy that some enteroendocrine cells express signaling elements involved in taste transduction (the gut's luminal glucose sensor), initiating the incretin response to elicit the release of glucagon-like peptide 1 (Kokrashvili et al., 2009a). Therefore, TRPM5's presence in these gut "taste cells" as well as in pancreatic $\beta$-cells will be interesting to explore in diabetes and obesity.

\section{Transient Receptor Potential M6/M7 Subgroup}

TRPM6 and TRPM7 are unique among ion channels because they possess both ion channel and protein kinase activities. TRPM6 and TRPM7 serine/threonine kinase domains are located at the extreme $\mathrm{C}$ terminus, and the catalytic core of the kinase domain is similar to that of other eukaryotic protein kinases and to enzymes with "ATP-grasp" domains. High-resolution structure of the M7 kinase alone demonstrates marked similarities to protein kinase A (Yamaguchi et al., 2001). The kinase domain does not seem to affect channel activity in any direct manner. Both proteins also share similar biophysical properties; these channels allow $\mathrm{Mg}^{2+}$ and $\mathrm{Ca}^{2+}$ into the cell (albeit at very low conductances) and allow primarily monovalent $\mathrm{K}^{+}$out of the cell. They are strongly outwardly rectifying under physiological conditions. In the absence of divalent cations, their currentvoltage relations are practically linear, indicating that divalent ions bind the pore to regulate conductance. At positive voltages, TRPM6 and TRPM7 have single-channel conductances of 84 and $105 \mathrm{pS}$, respectively. Both channels are inhibited by intracellular $\mathrm{Mg}^{2+}(0.3-1.0$ mM) (Nadler et al., 2001; Voets et al., 2004b), but the inward current is strongly potentiated by extracellular acidic pH selectively (Jiang et al., 2005). However, homomeric TRPM6 and TRPM7 channels can be distinguished pharmacologically. For example, micromolar levels of 2-APB increase TRPM6 but inhibit TRPM7 channel activities, whereas millimolar concentrations of 2-APB potentiate TRPM7 channel activities ( $\mathrm{Li}$ et al., 2006).

TRPM6 is primarily expressed in kidney and intestine, where it has been suggested to be responsible for epithelial $\mathrm{Mg}^{2+}$ reabsorption, based largely on the identification of TRPM6 mutants in a hereditary disease called hypomagnesemia with secondary hypocalcemia (Schlingmann et al., 2002; Walder et al., 2002). The symptom of the disease could be alleviated significantly by dietary supplements of high-dose $\mathrm{Mg}^{2+}$ (Schlingmann and Gudermann, 2005). TRPM6(-/-) mice were generated, but many of them died by embryonic day 12.5. These mice had neural tube defects with exencephaly and spina bifida occulta. Feeding dams a high$\mathrm{Mg}^{2+}$ diet improved offspring survival. These results indicate a critical role for TRPM6 in neural tube closure in development (Walder et al., 2009).

TRPM7 is a large protein (1863 amino acids), identified in a yeast two-hybrid screen as a protein interacting with PLC $\beta 1$ (Runnels et al., 2001). In contrast to other GPCRactivated TRP channels, TRPM7 current increases slowly under whole-cell recording conditions and is inactivated by $\mathrm{PIP}_{2}$ hydrolysis by PLC $\beta$ or PLC $\gamma$ (Runnels et al., 2002). TRPM7 autophosphorylates (Matsushita et al., 2005) and can phosphorylate proteins such as annexin 2 (Dorovkov and Ryazanov, 2004) and myosin IIA heavy chain (Clark et al., 2006), but its native substrates have not been identified.

Native activation of the TRPM7 channel is, as for most TRP channels, an unsolved mystery. Upon break-in during whole-cell recording, TRPM7 currents continually increase over time until they are quite large. This increase does not occur under perforated-patch conditions, in which intracellular perfusion is restricted to ions, suggesting that an intracellular inhibitor (in addition to $\mathrm{Mg}^{2+}$ ) normally limits current (L. J. Wu, B. Navarro, and D. E. Clapham, unpublished observations). TRPM7 expressed in a vascular smooth muscle cell line is subtly increased by shear stress apparently via insertion of additional TRPM7 into the plasma membrane (Oancea et al., 2006), but TRPM7 is not in any traditional sense a mechanosensitive channel. In addition to $\mathrm{Mg}^{2+}$ and $\mathrm{Ca}^{2+}$, TRPM7 is permeable to $\mathrm{Zn}^{2+}, \mathrm{Co}^{2+}$, and $\mathrm{Mn}^{2+}$, providing a potential ion channel mechanism for cellular entry of trace metal ions (MonteilhZoller et al., 2003).

TRPM7 is ubiquitously expressed but the expression level is low in most tissues. Suppression of TRPM7 expression reduced $\mathrm{Ca}^{2+}$-dependent anoxic death in neuronal culture, as well as in mice with stroke (Aarts et al., 2003; Sun et al., 2009). TRPM7 was proposed, based on knockout of TRPM7, in DT-40 chicken B-lymphocyte cell lines, to be important for $\mathrm{Mg}^{2+}$ homeostasis (Schmitz et al., 2003). Genetic deletion of TrpM7 is lethal before embryonic day 7.5, suggesting that TRPM7 is essential for embryonic development (Jin et al., 2008). Tissue- 
specific deletion of TRPM7 in the T-cell lineage results in a developmental block of thymocytes at the doublenegative stage. Careful quantitation of intracellular $\mathrm{Mg}^{2+}$ changes in response to rapid changes in external $\mathrm{Mg}^{2+}$ levels did not alter global intracellular $\mathrm{Mg}^{2+}$. In addition, total $\mathrm{Mg}^{2+}$ levels in cells did not differ between $\mathrm{T}$ cells in wild-type and conditional TRPM7(-/-) mice (Jin et al., 2008). Thus, TRPM7 does not have an important function in $\mathrm{Mg}^{2+}$ homeostasis in $\mathrm{T}$ cells, although localized changes in intracellular $\mathrm{Mg}^{2+}$ may be relevant to its function. These findings also raise questions regarding the mechanism of hypomagnesemia (in hypomagnesemia with secondary hypocalcemia) that can be resolved by mutation of TRPM6 in animal models. A report that mutations in TRPM7 (threonine-to-isoleucine substitution at position 1482) in amyotrophic lateral sclerosis-Parkinsonism/dementia complex (Hermosura et al., 2005) has been challenged by a recent linkage study (Hara et al., 2010).

It is noteworthy that TRPM7 is localized to a distinct set of vesicles in some cells. TRPM7 resides in the membrane of synaptic vesicles of sympathetic neurons, forms molecular complexes with the synaptic vesicle proteins synapsin I and synaptotagmin I, and directly interacts with synaptic vesicular snapin. In sympathetic neurons, changes in TRPM7 levels and channel activity alter acetylcholine release. Thus, vesicular TRPM7 channel activity is critical to neurotransmitter release in sympathetic neurons (Krapivinsky et al., 2006). How would vesicle-localized TRPM7 mediate fusion? First, remember that ion channels being trafficked to the plasma membrane are assembled with the outer vestibule of the pore facing the inside of the vesicle. The cytoplasmic domains remain cytoplasmic before and after fusion. When TRPM7 is vesicular, its "outer" surface faces high potentiating ( $\mathrm{Li}$ et al., 2007) $\mathrm{pH}$. Vesicular membranes typically lack $\mathrm{PIP}_{2}$ in contrast to the $\mathrm{PIP}_{2}$-rich plasma membrane, and TRPM7 should be closed under this condition. When the vesicle approaches the membrane, its cytoplasmic domains are exposed to the high $\mathrm{PIP}_{2}$ levels of the plasma membrane, and the channel should open in its high divalent conductance state (low intravesicular $\mathrm{pH}$ ). In this model, TRPM7 acts as a coincidence detector, opening only when vesicular $\mathrm{pH}$ is low, and $\mathrm{PIP}_{2}$ in the plasma membrane binds cytoplasmic domains of TRPM7. TRPM7 opening at this point would allow ion exchange between the vesicular and cytoplasmic spaces (Montell, 2006; Brauchi et al., 2008).

\section{E. Transient Receptor Potential M8}

Like TRPM1, TRPM8 was originally identified in a screen of cancer-related genes (Tsavaler et al., 2001). TRPM8 is permeant to $\mathrm{Ca}^{2+}\left(\mathrm{P}_{\mathrm{Ca}} / \mathrm{P}_{\mathrm{Na}} \sim 1-3\right)$ and has a single-channel conductance of $\sim 80 \mathrm{pS}$. Its sensory role was recognized when it was isolated by expression cloning of a menthol receptor from trigeminal neurons (McKemy et al., 2002) and by bioinformatics approaches using TRP channel sequence homology (Peier et al., $2002 \mathrm{a})$. It can be activated by cold $\left(8-28^{\circ} \mathrm{C}\right)$ and enhanced by cooling compounds such as menthol and icilin (McKemy et al., 2002; Peier et al., 2002a). Temperature modulates the voltage dependence of the channel, menthol and icilin mimicking this effect (Voets et al., 2004a). However, menthol and icilin may activate the TRPM8 through distinct mechanisms. For example, menthol activation is unaffected by intracellular $\mathrm{pH}$ and is inhibited by intracellular $\mathrm{Ca}^{2+}$, whereas icilin activation is inhibited by low $\mathrm{pH}$ and by the absence of intracellular $\mathrm{Ca}^{2+}$ (Andersson et al., 2004; Chuang et al., 2004). Mutational analyses indicate that residues in the S1 and S2 transmembrane segments are required for TRPM8 activation by menthol and icilin (Chuang et al., 2004; Bandell et al., 2006), whereas S4 and the S4-S5 linker of TRPM8 may mediate voltage sensing and some aspect of menthol binding (Voets et al., 2007).

TRPM8 is widely expressed, but its most clear-cut function is as a cold sensor in $\operatorname{TrkA}^{+}$small-diameter primary sensory neurons. Indeed, three independent studies showed that TRPM8(-/-) mice have remarkable deficiencies to a range of cold responses (Bautista et al., 2007; Colburn et al., 2007; Dhaka et al., 2007). This suggests that TRPM8 is the predominant detector of cold temperatures in vivo, which has implication for somatosensation, nociception, and the development of analgesia. TRPM8 is also identified in other tissues; for example, the prostate epithelium (Tsavaler et al., 2001), where it may act as an androgen-responsive channel (Zhang and Barritt, 2004), and in arterial vascular smooth muscle, where it may regulate vascular tone (Johnson et al., 2009). High concentrations of menthol were used to argue that TRPM8 is also expressed in human sperm to regulate the acrosome reaction (De Blas et al., 2009), but TRPM8(-/-) fertility is normal (Bautista et al., 2007; Colburn et al., 2007; Dhaka et al., 2007).

\section{The Transient Receptor Potential (Ankyrin) Family}

TRPA1 (Fig. 4) is the only member of the mammalian family, but it seems to have arisen from larger families in insects that critically depend on chemosensation. The "A" in TRPA1 stands for ankyrin, because the protein contains at least 14 ankyrin repeats in its $\mathrm{N}$ terminus. These repeats are hypothesized to interact with cytoskeletal components (Howard and Bechstedt, 2004; Sotomayor et al., 2005) or to modulate ligand binding (Lishko et al., 2007). TRPA1 also contains an N-terminal $\mathrm{Ca}^{2+}$ binding EF hand domain. TRPA1 is selectively expressed in a subpopulation of neurons in the dorsal root, trigeminal, and nodose ganglia (Story et al., 2003; Diogenes et al., 2007; Brierley et al., 2009), as well as in hair and skin cells (Corey et al., 2004; Atoyan et al., 2009; Kwan et al., 2009). There it primarily acts as a 
A
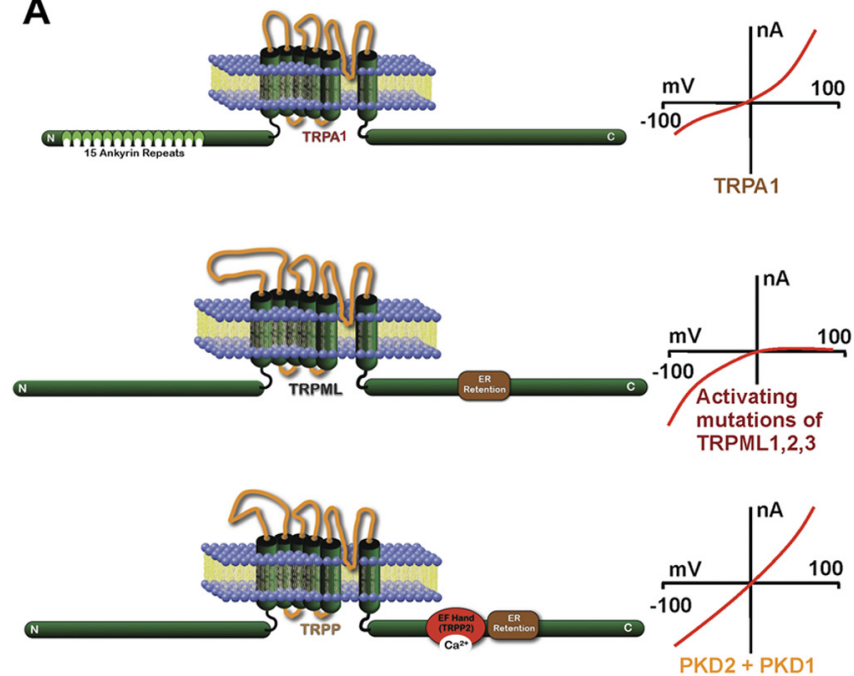

B

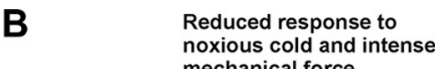

mechanical force

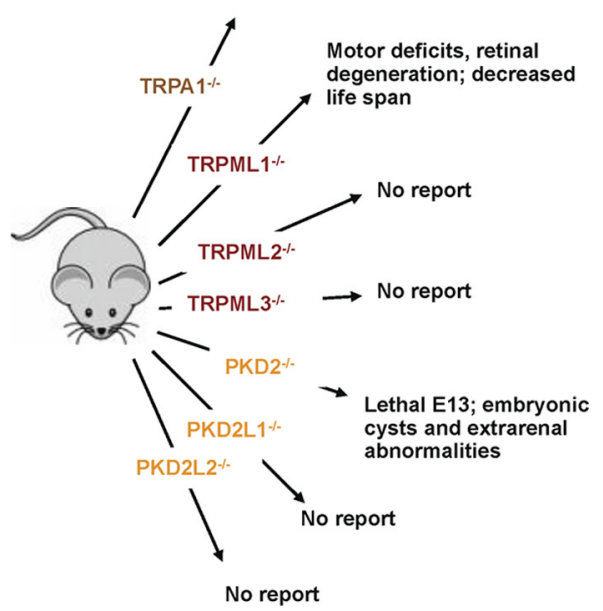

FIG. 4. TRPA1 (ankyrin repeat), TRPML (mucolipin) and TRPP [polycystic kidney disease 2 (PKD2), also called polycystin 2 (PC2)] channels. A, "distal" TRP molecular domains and their current-voltage relationships. The ER retention signal is a small domain that presumably maintains the channel in the endoplasmic reticulum. Note that the current-voltage relationship for TRPA1 shows decay at positive potentials in most whole-cell recordings and is linear with electrophilic agonist. B, major phenotypes in "distal" TRP channel knockout mice. Note: the PKD1 refers to the 11-TM domain-containing protein of the polycystin 1 family. TRPP (PKD2, polycystin 2, PC2) refers to the 6-TM family of proteins.

chemosensor and, in some cases, may amplify $\mathrm{Ca}^{2+}$. entry through other channels (Jordt et al., 2004; Bautista et al., 2005; Zurborg et al., 2007). A recent study found that a gain-of-function mutation (N855S) in the S4 transmembrane segment of TRPA1 causes familial episodic pain syndrome, providing the first example of a human pain-associated TRP channelopathy (Kremeyer et al., 2010).

TRPA1 is activated by a variety of chemicals, including cinnamaldehyde (in cinnamon) (Bandell et al., 2004), allicin, and diallyl disulfide (in garlic) (Bautista et al., 2005; Macpherson et al., 2005), isothiocyanates (in mustard oil, wasabi, and horseradish) (Bandell et al., 2004; Jordt et al., 2004), methyl salicylate (in winter green oil) (Bandell et al., 2004), acrolein (in smoke) (Bautista et al., 2006), and $\Delta^{9}$-tetrahydrocannabinol (in marijuana) (Jordt et al., 2004). In addition, the well known TRPM8 agonist menthol has a bimodal effect: it activates TRPA1 at low concentrations and inhibits it at high concentrations (Macpherson et al., 2006; Karashima et al., 2007). More recently, the endogenous compounds 4-hydroxynonenal and 15-deoxy$\Delta^{12,14}$-prostaglandin $\mathrm{J} 2$, which can be released in response to tissue injury, inflammation, and oxidative stress were reported to be activators of TRPA1 (Macpherson et al., 2007b; Trevisani et al., 2007; Taylor-Clark et al., 2008). Many of the TRPA1 agonists are thiol-reactive electrophiles that activate TRPA1 through covalent interactions with cysteine residues in the channel $\mathrm{N}$ terminus, although other modifications are likely (Hinman et al., 2006; Macpherson et al., 2007a). Schmidt et al. (2009) recently reported that TRPA1 activation by mustard oil may be the result of increased protein kinase A/PLC-mediated trafficking to the membrane (Schmidt et al., 2009).
TRPA1 activity is potentiated and subsequently inactivated by extracellular $\mathrm{Ca}^{2+}$. This modulation is indirect and attributed to $\mathrm{Ca}^{2+}$ entry through TRPA1; the intracellular $\mathrm{Ca}^{2+}$-binding EF-hand motif is apparently not required (Wang et al., 2008).

In addition to chemical activation, it has been proposed that TRPA1 is directly activated by noxious cold $\left(<17^{\circ} \mathrm{C}\right)$; however, the thermosensitivity of TRPA1 is debated. Numerous groups have reported that heterologously expressed TRPA1 is activated by noxious cold (Story et al., 2003; Bandell et al., 2004; Sawada et al., 2007; Karashima et al., 2009); however, other groups found no direct cold activation (Jordt et al., 2004; Nagata et al., 2005; Zurborg et al., 2007). Initial reports after the generation of two independent TRPA1(-/-) mice only contributed to the controversy. Whereas one study reported mild and sex-dependent alterations in the behavioral response to prolonged exposure to noxious cold in TRPA1(-/-) mice (Kwan et al., 2006), the second study found no sign of altered cold sensitivity in these mice (Bautista et al., 2006). A recent study identified a specific subset of cold-sensitive trigeminal ganglion neurons that is absent in TRPA1 $(-/-)$ mice and suggested that although TRPA1 is not required for sensing acute cold stimuli, it is required for behavioral responses to prolonged noxious cold (Karashima et al., 2009). The marked $\mathrm{Ca}^{2+}$ regulation of this channel under different conditions, strain differences, or the degree to which mice were back-crossed onto a common background, may underlie some of these discrepancies. It is noteworthy that TRPA1 orthologs from pit-bearing snakes are demonstrated to be the most heat-sensitive vertebrate ion channels and may play a role in detecting infrared radiation (Gracheva et al., 2010). 
Detection of TRPA1 in hair cells in the ear (Corey et al., 2004; Nagata et al., 2005) led to the proposal that it forms the auditory mechanotransduction channel (Corey et al., 2004). However, heterologously expressed TRPA1 channels have not been shown to be mechanosensitive, and hair cells do not respond to mustard oil or other TRPA1 agonists (Corey, 2006). In addition, TRPA1(-/-) mice exhibit no overt vestibular defects, and their auditory responses are completely normal (Bautista et al., 2006; Kwan et al., 2006). In summary, there is no convincing evidence that TRPA1 itself is a mechanosensor in any cell type.

\section{The Transient Receptor Potential (Mucolipin) Family}

The mucolipin TRP (TRPML; Fig. 4) proteins are primarily intracellular and are likely to be important for compartment trafficking and/or function (Bargal and Bach, 1997; Chen et al., 1998; Kim et al., 2009; Cheng et al., 2010b).

The founding member of the TRPML family, TRPML1, was first identified in linkage studies as the gene mutated in humans in Mucolipidosis type IV (MLIV), a progressive neurodegenerative disease of young children (Bargal et al., 2000; Bassi et al., 2000; Sun et al., 2000). MLIV is characterized clinically by severe motor deficits, mental retardation, retinal degeneration, iron-deficiency anemia, and elevated gastrin levels as a result of achlorhydria (Slaugenhaupt, 2002). At the cellular level, various materials [such as sphingolipids (mostly gangliosides), phospholipids, and acid mucopolysaccharides] accumulate in the lysosomes of patients with MLIV and appear as membrane-bound granular inclusions or lamellar concentric bodies. In contrast with other lysosomal storage diseases, the accumulation of heterogeneous storage material in MLIV lysosomes does not result from a block in catabolic pathways-lysosomal hydrolases are functional and correctly transported to the lysosomes; rather, it probably results from an ill-defined sorting, transport, or functional defect along the late endocytic pathway (Bargal and Bach, 1988; Chen et al., 1998).

Congruent with the ubiquitous lysosomal phenotype of MLIV patients, TRPML1 is expressed in cells of every tissue and localizes primarily to the lysosomal and late endosomal compartments (Manzoni et al., 2004; Kiselyov et al., 2005). TRPML1 contains two di-leucine motifs, one on its $\mathrm{C}$ terminus and one on its $\mathrm{N}$ terminus, that are likely to restrict its localization. In addition, TRPML1 has a large intraluminal loop between its first and second transmembrane domains that contains a putative serine-lipase site, a proline-rich domain, and a proteolytic cleavage site (Slaugenhaupt, 2002). This loop may interact with chaperone-mediated autophagy-related proteins, heat shock cognate protein of $70 \mathrm{kDa}$, and the 40-kDa heat shock protein (Venugopal et al., 2009). Currents recorded from late endosomes and lysosomes suggest that TRPML1 forms an inwardly rectifying, proton-impermeable, cation-selective channel with perme- ability to both $\mathrm{Ca}^{2+}$ and $\mathrm{Fe}^{2+}$. This permeability is potentiated by low luminal $\mathrm{pH}$ (Xu et al., 2007; Dong et al., 2008, 2009).

The inward rectification of TRPML1 indicates that when present in lysosomes, TRPML1 would primarily move cations out of the lysosomal lumen, depending on the translysosomal voltage and concentration gradients. This suggests that TRPML1 could function as a $\mathrm{Ca}^{2+}$ or $\mathrm{Fe}^{2+}$ release channel (Dong et al., 2008). Supporting this view, release of iron from late endosomes and lysosomes into the cytosol is essential for cellular iron metabolism and TRPML1(-/-) cells show altered iron homeostasis (Dong et al., 2008). Exocytosis from lysosomes are $\mathrm{Ca}^{2+}$ regulated, and one of the major sources of $\mathrm{Ca}^{2+}$ for this process is the lysosome itself (Peters and Mayer, 1998). Constitutively active TRPML1 mutants exhibit significant expression at the plasma membrane, whereas wildtype TRPML1 and non-gain-of-function mutants localize exclusively to the late endosomes and lysosomes (Dong et al., 2009). Consistent with a role for TRPML1 in $\mathrm{Ca}^{2+}$-dependent lysosomal exocytosis, surface staining of lysosomal-associated membrane protein type 1 , a lysosomal marker, is dramatically increased in cells expressing constitutive active TRPML1 (Dong et al., 2009). In chaperone-mediated autophagy, proteins are directly transported through the lysosomal membrane, recognized by heat shock cognate protein of $70 \mathrm{kDa}$, and bound to the lysosomal membrane through interaction with LAMP-2A (Chiang et al., 1989; Cuervo and Dice, 1996). It is noteworthy that overexpression of the mammalian homolog of HSC70 in a fly model of MLIV rescued the motor deficits associated with TRPML1 deficiency (Venkatachalam et al., 2008). TRPML1(-/-) mice have been generated, and they largely recapitulated the phenotypes displayed in humans with MLIV, showing motor deficits, central nervous system inclusions, retinal degeneration, elevated plasma gastrin, and decreased life span (Venugopal et al., 2007).

Like TRPML1, TRPML2 is an inwardly rectifying $\mathrm{Ca}^{2+}$ - and $\mathrm{Fe}^{2+}$-permeable cation-selective channel potentiated by low pH (Dong et al., 2008; Samie et al., 2009). TRPML2 is expressed in cells of all tissues, where it localizes primarily to intracellular compartments $\mathrm{Xu}$ et al., 2007; Samie et al., 2009; Zeevi et al., 2009). Knockdown of endogenous TRPML2 expression in HEK293 cells leads to lysosomal storage and mitochondrial abnormalities (Zeevi et al., 2009). Functional studies suggest that TRPML2 may regulate the trafficking between recycling endosomes and the cell surface through an Arf6 clathrin-independent pathway (Karacsonyi et al., 2007). Generation of TRPML2(-/-) mice may help to elucidate the role of TRPML2 in vivo.

TRPML3 is an inwardly rectifying cation-selective channel that is regulated by extracellular/luminal $\mathrm{pH}$ (Grimm et al., 2007; Xu et al., 2007; Kim et al., 2008b). TRPML3 was discovered by positional cloning as the channel mutated in varitint-waddler mice, which are 
characterized by a variegated/dilute coat color owing to pigmentation defects, hearing loss, circling behavior caused by vestibular defects, hyperactivity, and embryonic lethality (Cable and Steel, 1998; Di Palma et al., 2002; Xu et al., 2007). The varitint-waddler phenotype is caused by the gain-of-function mutation (A419P) in the S6 of TRPML3 (Grimm et al., 2007; Kim et al., 2007; Xu et al., 2007). This mutation is a helix-breaking proline substitution that creates a constitutively active channel and eliminates regulation of the channel by extracytosolic cations (Grimm et al., 2007; Kim et al., 2007). Constitutive activation of the channel leads to increased $\mathrm{Ca}^{2+}$ influx and cell death (Xu et al., 2007); the loss of melanocytes in the cochlea and vestibulum probably underlies the deafness and the circling behavior of varitint-waddler mice (Cable and Steel, 1998; Xu et al., 2007). However, other than constitutive activation of the helix-break mutants, wild-type TRPML3 activation is not well understood. TRPML3 can be activated by preincubation in low- $\mathrm{Na}^{+}$medium (Kim et al., 2008b). A recent report using a high-throughput chemical screen has identified a plethora of TRPML3 activators that will hopefully serve as useful tools (Grimm et al., 2010).

Mirroring its functional deficits, TRPML3 expression has been reported in the hair cells of the cochlea and the vestibulum, as well as in the melanocytes in skin hair follicles (Di Palma et al., 2002; van Aken et al., 2008). At the cellular level, TRPML3 can be detected in intracellular vesicular compartments and in the plasma membrane. Knockdown of TRPML3 expression or expression of a dominant-negative version of the channel stimulated endocytosis of transferrin and EGF/EGFR, whereas overexpression of TRPML3 inhibited these same processes (Kim et al., 2009). Knockdown of endogenous TRPML3 causes lysosomal storage and mitochondrial abnormalities (Zeevi et al., 2009).

\section{The Transient Receptor Potential (Polycystin)/Polycystic Kidney Disease 2 Family}

TRPP refers to the polycystic kidney disease 2 (PKD2; Fig. 4) subset of the polycystins. Polycystins include putative 11-TM (PKD1, also called the PC1 family) and 6-TM subfamilies (PKD2, also called the PC2 family). The TRPP family nomenclature is confused by the previous inclusion of the 11-TM subfamily. Because there is little support for the 11TM group forming functional channels, we will only discuss the 6TM (PKD2, PC2) family. To avoid confusion, we use the PKD2 nomenclature but provide previous names associated with each.

Increasing evidence suggests that PKD1 subgroup members associate with PKD2 members to form heterocomplexes (Qian et al., 1997; Tsiokas et al., 1997) and that they share a notable number of physiological functions (Hanaoka et al., 2000; McGrath et al., 2003; LopezJimenez et al., 2006; Vogel et al., 2010). The PKD2 subgroup consists of three members, PKD2, PKD2L1, and PKD2L2, all of which have 6 TM-spanning domains and intracellular $\mathrm{N}$ and $\mathrm{C}$ termini. Based on their homology to other TRP family members, they are expected to assemble in a tetrameric structure to form $\mathrm{Ca}^{2+}$ permeable nonselective cation channels.

PKD2 (TRPP1, also called PC2, and TRPP2 in older nomenclature) was originally identified in linkage studies for autosomal dominant polycystic kidney disease (ADPKD) (Peters et al., 1993; Mochizuki et al., 1996). ADPKD is characterized by the progressive development of multiple fluid-filled cysts in the kidney, pancreas, and liver and an increased prevalence of cardiovascular abnormalities such as hypertension, mitral valve prolapse, and intracranial aneurysm (Gabow, 1993; Torra et al., 2000). Approximately 15\% of clinical cases of ADPKD present with mutations in the PKD2 gene loci (Peters et al., 1993). The cystic phenotype and extrarenal abnormalities are largely recapitulated in PKD2(-/-) mice, and the mice die in utero between embryonic day 13.5 and parturition (Wu et al., 2000).

PKD2 is reported to form a $\mathrm{Ca}^{2+}$-permeable nonselective cation channel that can be activated by downstream of $G$ protein-coupled receptor and/or receptor-tyrosine kinase at the cell surface (Ma et al., 2005; Bai et al., 2008b) and is regulated by phosphoinositides (Ma et al., 2005), $\mathrm{Ca}^{2+}$ (Vassilev et al., 2001; Koulen et al., 2002), and pH (Gonzalez-Perrett et al., 2002). Controversy surrounds PKD2 currents, because in most cell-based systems, PKD2 does not traffic to the plasma membrane and is retained in endoplasmic reticulum (Hanaoka et al., 2000; Vassilev et al., 2001; Koulen et al., 2002). There is good agreement, however, that PKD2 associates with PKD1 through its Cterminal coiled-coil domain (Bai et al., 2008a; Celić et al., 2008; Yu et al., 2009). The functional importance of the coiled-coil domain is underscored by the many naturally occurring ADPKD pathogenic truncations, including R742X, R807X, E837X, and R872X, in PKD2 (SharifNaeini et al., 2009), which eliminate the coiled-coil domain or the downstream open region and abolish the assembly of the PKD1-PKD2 complex.

PKD2 is widely expressed in both fetal and adult tissues. A pool of PKD2 has been proposed to localize to cilia through a motif in its $\mathrm{N}$ terminus (Geng et al., 2006). In the primary cilia of renal epithelial cells and vascular endothelial cells, PKD2, in conjunction with PKD1, may be required for transduction of extracellular shear stress induced by blood or urine flow into intracellular $\mathrm{Ca}^{2+}$ signals (Nauli et al., 2008; AbouAlaiwi et al., 2009). Thus, it was proposed that PKD2, perhaps in association with PKD1 and/or TRPV4, is a mechanosensitive channel. There is, however, very little direct support for this idea, and a recent study suggests that PKD2 is not itself a mechanosensitive channel but instead regulates mechanosensory channels (Sharif-Naeini et al., 2009), perhaps through the numerous reported interactions with the actin filament associated proteins. PKD2 is also expressed in nodal cilia, where it is re- 
quired for the development of left-right asymmetry of the thoracic and visceral organs (McGrath et al., 2003).

$\mathrm{PKD} 2$ is present in the endoplasmic reticulum. The $\mathrm{C}$ terminus of PKD2 may bind PACS and PRKCSH/ $80 \mathrm{~K}-\mathrm{H}$, which retain proteins in the endoplasmic reticulum (Köttgen et al., 2005) and protect it from homocysteine-induced endoplasmic reticulum protein-mediated degradation (Gao et al., 2010), respectively. In the endoplasmic reticulum, it has been proposed that PKD2 forms a $\mathrm{Ca}^{2+}$ release channel and modulates release of intracellular $\mathrm{Ca}^{2+}$ (Koulen et al., 2002; Geng et al., 2008). To reconcile disparate findings, an appealing model is one in which PKD1 on the plasma membrane interacts with PKD2 in the endoplasmic reticulum.

PKD2L1 (TRPP2, also called TRPP3 in older nomenclature) is reported to form an inwardly rectifying $\mathrm{Ca}^{2+}$. permeable nonselective cation channel with a large single channel conductance modulated by $\mathrm{pH}$ (Huang et al., 2006; Ishimaru et al., 2006; Shimizu et al., 2009). Concrete evidence that these currents are mediated by the PKD2L1 alone is lacking. The expression pattern of PKD2L1 is also debated. At both the mRNA and protein levels, PKD2L1 has been reported in multiple tissues, including the kidney, retina, liver, pancreas, heart, spleen, and brain (Nomura et al., 1998; Basora et al., 2002). More recently, the expression pattern of PKD2L1 seems to be restricted to testis, taste tissue, and in a specific subset of neurons surrounding the central canal of spinal cord (Huang et al., 2006; Ishimaru et al., 2006). In taste tissue, PKD2L1 colocalizes with PKD1L3 in a subpopulation of taste receptor cells, where they may function as sour $\left(\mathrm{H}^{+}\right)$receptors (LopezJimenez et al., 2006). In support of this idea, mice lacking PKD2L1expressing cells, as a result of diphtheria toxin-mediated ablation, exhibit no gustatory nerve response to acidic stimuli in the chorda tympani nerves (Huang et al., 2006). However, in vivo behavior analyses revealed that PKD2L1(-/-) mice retain normal sensation to sour as well as sweet, bitter, and salty tastes (L. Guo and J. Zhou, unpublished observations). After PKD2L1 expression in a subset of $\mathrm{pH}$-sensitive neurons surrounding the central canal of the spinal cord, it has also been proposed to serve as a chemosensor sensing the internal state of spinal fluid (Huang et al., 2006).

PKD2L2 (TRPP3, also called TRPP5 in older literature) is the least well understood member of the TRP family. Although PKD2L2 is expected to form a $\mathrm{Ca}^{2+}$. permeable nonselective cation channel (Guo et al., 2000), only limited support for this hypothesis exists. Overexpression of PKD2L2 in Madin-Darby canine kidney cells resulted in elevated levels of intracellular $\mathrm{Ca}^{2+}$ (Chen et al., 2008b), and outside-out patches from PKD2L2-transfected HEK293 cells revealed a channel with a single 25 -pS conductance state that could not be measured in control cells (Sutton et al., 2006). Northern blot analysis indicates that PKD2L2 is expressed in mouse heart and testis, whereas reverse transcription- polymerase chain reaction analysis showed that in humans, PKD2L2 is expressed in brain, kidney, and testis (Guo et al., 2000). Immunohistochemical staining detects PKD2L2 in the plasma membrane of spermatocytes and round spermatids (Chen et al., 2008b), suggesting its potential role in spermatogenesis.

\section{Summary}

In this review, we have attempted to capture the current state of understanding of the function of the large class of mammalian TRP channels. The TRP literature has become so large that many works in the area could not be credited adequately. The TRP channels currently seem to have arisen in eukaryotes to fulfill cellular sensing in response to diverse environmental stimuli by reducing transmembrane (both intracellular and plasma membrane) voltages and often permeating divalent cations. The most common features are their weak voltage sensitivities, potentiation by phospholipase C-linked receptors, and modulation by positively charged intracellular divalent ions and the negatively charged molecules $\mathrm{Ca}^{2+} / \mathrm{CaM}$ and $\mathrm{PIP}_{2}$. One unusual features of this class of channels are their (often) dual functional relevance in both intracellular compartments and on the plasma membrane in response to extracellular stimuli, perhaps serving to deliver themselves to the plasma membrane by providing $\mathrm{Ca}^{2+}$ to intracellular synaptotagmins required for fusion. Another unusual feature is that several are permeant to $\mathrm{Mg}^{2+}$ and other divalent ions that are much too large (because of their large dehydration energies) to permeate other ion channels. The most significant development in the field is that knockout mice are now available for practically all TRP channels, which will enable more exacting determination of function and proper characterization of antibodies used in localization studies.

Acknowledgments. This work is supported by the National Institutes of Health National Institute of Mental Health [Grant R01MH090293-01] and a Harvard Medical School Lefler postdoctoral fellowship (to L.-J.W.).

\section{REFERENCES}

Aarts M, Iihara K, Wei WL, Xiong ZG, Arundine M, Cerwinski W, MacDonald JF, and Tymianski M (2003) A key role for TRPM7 channels in anoxic neuronal death Cell 115:863-877.

AbouAlaiwi WA, Takahashi M, Mell BR, Jones TJ, Ratnam S, Kolb RJ, and Nauli SM (2009) Ciliary polycystin-2 is a mechanosensitive calcium channel involved in nitric oxide signaling cascades. Circ Res 104:860-869.

Al-Ansary D, Bogeski I, Disteldorf BM, Becherer U, and Niemeyer BA (2010) ATP modulates $\mathrm{Ca}^{2+}$ uptake by TRPV6 and is counteracted by isoform-specific phosphorylation. FASEB J 24:425-435.

Alessandri-Haber N, Dina OA, Joseph EK, Reichling D, and Levine JD (2006) A transient receptor potential vanilloid 4-dependent mechanism of hyperalgesia is engaged by concerted action of inflammatory mediators. J Neurosci 26:3864-3874. Alvarez DF, King JA, Weber D, Addison E, Liedtke W, and Townsley MI (2006) Transient receptor potential vanilloid 4-mediated disruption of the alveolar septal barrier: a novel mechanism of acute lung injury. Circ Res 99:988-995.

Amaral MD and Pozzo-Miller L (2007) TRPC3 channels are necessary for brainderived neurotrophic factor to activate a nonselective cationic current and to induce dendritic spine formation. $J$ Neurosci 27:5179-5189.

Andersson DA, Chase HW, and Bevan S (2004) TRPM8 activation by menthol, icilin, and cold is differentially modulated by intracellular $\mathrm{pH}$. J Neurosci 24:5364-5369. Asakawa M, Yoshioka T, Matsutani T, Hikita I, Suzuki M, Oshima I, Tsukahara K, Arimura A, Horikawa T, Hirasawa T, et al. (2006) Association of a mutation in TRPV3 with defective hair growth in rodents. J Invest Dermatol 126:2664-2672. 
Atoyan R, Shander D, and Botchkareva NV (2009) Non-neuronal expression of transient receptor potential type A1 (TRPA1) in human skin. J Invest Dermatol 129:2312-2315.

Audo I, Kohl S, Leroy BP, Munier FL, Guillonneau X, Mohand-Saïd S, Bujakowska K, Nandrot EF, Lorenz B, Preising M, et al. (2009) TRPM1 is mutated in patients with autosomal-recessive complete congenital stationary night blindness. Am J Hum Genet 85:720-729.

Auer-Grumbach M, Olschewski A, Papić L, Kremer H, McEntagart ME, Uhrig S, Fischer C, Fröhlich E, Bálint Z, Tang B, et al. (2010) Alterations in the ankyrin domain of TRPV4 cause congenital distal SMA, scapuloperoneal SMA and HMSN2C. Nat Genet 42:160-164.

Bai CX, Giamarchi A, Rodat-Despoix L, Padilla F, Downs T, Tsiokas L, and Delmas $\mathrm{P}$ (2008a) Formation of a new receptor-operated channel by heteromeric assembly of TRPP2 and TRPC1 subunits. EMBO Rep 9:472-479.

Bai CX, Kim S, Li WP, Streets AJ, Ong AC, and Tsiokas L (2008b) Activation of TRPP2 through mDia1-dependent voltage gating. EMBO J 27:1345-1356.

Bandell M, Dubin AE, Petrus MJ, Orth A, Mathur J, Hwang SW, and Patapoutian A (2006) High-throughput random mutagenesis screen reveals TRPM8 residues specifically required for activation by menthol. Nat Neurosci 9:493-500.

Bandell M, Story GM, Hwang SW, Viswanath V, Eid SR, Petrus MJ, Earley TJ, and Patapoutian A (2004) Noxious cold ion channel TRPA1 is activated by pungent compounds and bradykinin. Neuron 41:849-857.

Barbet G, Demion M, Moura IC, Serafini N, Léger T, Vrtovsnik F, Monteiro RC, Guinamard R, Kinet JP, and Launay P (2008) The calcium-activated nonselective cation channel TRPM4 is essential for the migration but not the maturation of dendritic cells. Nat Immunol 9:1148-1156.

Bargal R, Avidan N, Ben-Asher E, Olender Z, Zeigler M, Frumkin A, RaasRothschild A, Glusman G, Lancet D, and Bach G (2000) Identification of the gene causing mucolipidosis type IV. Nat Genet 26:118-123.

Bargal R and Bach G (1988) Phospholipids accumulation in mucolipidosis IV cultured fibroblasts. J Inherit Metab Dis 11:144-150.

Bargal R and Bach G (1997) Mucolipidosis type IV: abnormal transport of lipids to lysosomes. J Inherit Metab Dis 20:625-632.

Basora N, Nomura H, Berger UV, Stayner C, Guo L, Shen X, and Zhou J (2002) Tissue and cellular localization of a novel polycystic kidney disease-like gene product, polycystin-L. J Am Soc Nephrol 13:293-301.

Bassi MT, Manzoni M, Monti E, Pizzo MT, Ballabio A, and Borsani G (2000) Cloning of the gene encoding a novel integral membrane protein, mucolipidin-and identification of the two major founder mutations causing mucolipidosis type IV. Am J Hum Genet 67:1110-1120.

Bautista DM, Jordt SE, Nikai T, Tsuruda PR, Read AJ, Poblete J, Yamoah EN, Basbaum AI, and Julius D (2006) TRPA1 mediates the inflammatory actions of environmental irritants and proalgesic agents. Cell 124:1269-1282.

Bautista DM, Movahed P, Hinman A, Axelsson HE, Sterner O, Högestätt ED, Julius D, Jordt SE, and Zygmunt PM (2005) Pungent products from garlic activate the sensory ion channel TRPA1. Proc Natl Acad Sci USA 102:12248-12252.

Bautista DM, Siemens J, Glazer JM, Tsuruda PR, Basbaum AI, Stucky CL, Jordt SE, and Julius D (2007) The menthol receptor TRPM8 is the principal detector of environmental cold. Nature 448:204-208.

Becker EB, Oliver PL, Glitsch MD, Banks GT, Achilli F, Hardy A, Nolan PM, Fisher EM, and Davies KE (2009) A point mutation in TRPC3 causes abnormal Purkinje cell development and cerebellar ataxia in moonwalker mice. Proc Natl Acad Sci USA 106:6706-6711.

Benn BS, Ajibade D, Porta A, Dhawan P, Hediger M, Peng JB, Jiang Y, Oh GT, Jeung EB, Lieben L, et al. (2008) Active intestinal calcium transport in the absence of transient receptor potential vanilloid type 6 and calbindin-D9k. Endocrinology 149:3196-3205.

Berg AP, Sen N, and Bayliss DA (2007) TrpC3/C7 and Slo2.1 are molecular targets for metabotropic glutamate receptor signaling in rat striatal cholinergic interneurons. J Neurosci 27:8845-8856.

Bezzerides VJ, Ramsey IS, Kotecha S, Greka A, and Clapham DE (2004) Rapid vesicular translocation and insertion of TRP channels. Nat Cell Biol 6:709-720.

Bianco SD, Peng JB, Takanaga H, Suzuki Y, Crescenzi A, Kos CH, Zhuang L, Freeman MR, Gouveia $\mathrm{CH}$, Wu J, et al. (2007) Marked disturbance of calcium homeostasis in mice with targeted disruption of the Trpv6 calcium channel gene. $J$ Bone Miner Res 22:274-285.

Birder L, Kullmann FA, Lee H, Barrick S, de Groat W, Kanai A, and Caterina M (2007) Activation of urothelial transient receptor potential vanilloid 4 by 4 alphaphorbol 12,13-didecanoate contributes to altered bladder reflexes in the rat. $J$ Pharmacol Exp Ther 323:227-235.

Birder LA, Nakamura Y, Kiss S, Nealen ML, Barrick S, Kanai AJ, Wang E, Ruiz G, De Groat WC, Apodaca G, et al. (2002) Altered urinary bladder function in mice lacking the vanilloid receptor TRPV1. Nat Neurosci 5:856-860.

Blair NT, Kaczmarek JS, and Clapham DE (2009) Intracellular calcium strongly potentiates agonist-activated TRPC5 channels. J Gen Physiol 133:525-546.

Blednov YA and Harris RA (2009) Deletion of vanilloid receptor (TRPV1) in mice alters behavioral effects of ethanol. Neuropharmacology 56:814-820.

Bohlen CJ, Priel A, Zhou S, King D, Siemens J, and Julius D (2010) A bivalent tarantula toxin activates the capsaicin receptor, TRPV1, by targeting the outer pore domain. Cell 141:834-845.

Bölcskei K, Helyes Z, Szabó A, Sándor K, Elekes K, Németh J, Almási R, Pintér E, Petho G, and Szolcsányi J (2005) Investigation of the role of TRPV1 receptors in acute and chronic nociceptive processes using gene-deficient mice. Pain 117:368 376.

Brauchi S, Krapivinsky G, Krapivinsky L, and Clapham DE (2008) TRPM7 facilitates cholinergic vesicle fusion with the plasma membrane. Proc Natl Acad Sci USA 105:8304-8308.

Brierley SM, Hughes PA, Page AJ, Kwan KY, Martin CM, O'Donnell TA, Cooper NJ, Harrington AM, Adam B, Liebregts T, et al. (2009) The ion channel TRPA1 is required for normal mechanosensation and is modulated by algesic stimuli. Gas troenterology 137:2084-2095.
Brixel LR, Monteilh-Zoller MK, Ingenbrandt CS, Fleig A, Penner R, Enklaar T, Zabel BU, and Prawitt D (2010) TRPM5 regulates glucose-stimulated insulin secretion. Pflugers Arch 460:69-76.

Cable J and Steel KP (1998) Combined cochleo-saccular and neuroepithelial abnormalities in the Varitint-waddler-J (VaJ) mouse. Hear Res 123:125-136.

Caterina MJ, Leffler A, Malmberg AB, Martin WJ, Trafton J, Petersen-Zeitz KR, Koltzenburg M, Basbaum AI, and Julius D (2000) Impaired nociception and pain sensation in mice lacking the capsaicin receptor. Science 288:306-313.

Caterina MJ, Rosen TA, Tominaga M, Brake AJ, and Julius D (1999) A capsaicinreceptor homologue with a high threshold for noxious heat. Nature 398:436-441.

Caterina MJ, Schumacher MA, Tominaga M, Rosen TA, Levine JD, and Julius D (1997) The capsaicin receptor: a heat-activated ion channel in the pain pathway. Nature 389:816-824.

Celić A, Petri ET, Demeler B, Ehrlich BE, and Boggon TJ (2008) Domain mapping of the polycystin-2 C-terminal tail using de novo molecular modeling and biophysical analysis. J Biol Chem 283:28305-28312.

Chen CS, Bach G, and Pagano RE (1998) Abnormal transport along the lysosomal pathway in mucolipidosis, type IV disease. Proc Natl Acad Sci USA 95:6373-6378 Chen L, Liu C, and Liu L (2008a) Changes in osmolality modulate voltage-gated calcium channels in trigeminal ganglion neurons. Brain Res 1208:56-66.

Chen Y, Zhang Z, Lv XY, Wang YD, Hu ZG, Sun H, Tan RZ, Liu YH, Bian GH, Xiao $\mathrm{Y}$, et al. (2008b) Expression of Pkd2l2 in testis is implicated in spermatogenesis. Biol Pharm Bull 31:1496-1500.

Cheng X, Jin J, Hu L, Shen D, Dong XP, Samie MA, Knoff J, Eisinger B, Liu ML, Huang SM, et al. (2010a) TRP channel regulates EGFR signaling in hair morphogenesis and skin barrier formation. Cell 141:331-343.

Cheng X, Shen D, Samie M, and Xu H (2010b) Mucolipins: Intracellular TRPML1-3 channels. FEBS Lett 584:2013-2021.

Chiang HL, Terlecky SR, Plant CP, and Dice JF (1989) A role for a 70-kilodalton heat shock protein in lysosomal degradation of intracellular proteins. Science 246:382385

Chu CJ, Huang SM, De Petrocellis L, Bisogno T, Ewing SA, Miller JD, Zipkin RE, Daddario N, Appendino G, Di Marzo V, et al. (2003) N-oleoyldopamine, a novel endogenous capsaicin-like lipid that produces hyperalgesia. J Biol Chem 278: 13633-13639.

Chuang HH, Neuhausser WM, and Julius D (2004) The super-cooling agent icilin reveals a mechanism of coincidence detection by a temperature-sensitive TRP channel. Neuron 43:859-869.

Chuang HH, Prescott ED, Kong H, Shields S, Jordt SE, Basbaum AI, Chao MV, and Julius D (2001) Bradykinin and nerve growth factor release the capsaicin receptor from PtdIns(4,5)P2-mediated inhibition. Nature 411:957-962.

Chung MK, Lee H, Mizuno A, Suzuki M, and Caterina MJ (2004) TRPV3 and TRPV4 mediate warmth-evoked currents in primary mouse keratinocytes. J Biol Chem 279:21569-21575.

Clapham DE (2003) TRP channels as cellular sensors. Nature 426:517-524.

Clapham DE, Julius D, Montell C, and Schultz G (2005) International Union of Pharmacology. XLIX. Nomenclature and structure-function relationships of transient receptor potential channels. Pharmacol Rev 57:427-450.

Clark K, Langeslag M, van Leeuwen B, Ran L, Ryazanov AG, Figdor CG, Moolenaar WH, Jalink K, and van Leeuwen FN (2006) TRPM7, a novel regulator of actomyosin contractility and cell adhesion. EMBO J 25:290-301.

Colburn RW, Lubin ML, Stone DJ Jr, Wang Y, Lawrence D, D'Andrea MR, Brandt MR, Liu Y, Flores CM, and Qin N (2007) Attenuated cold sensitivity in TRPM8 null mice. Neuron 54:379-386.

Colsoul B, Schraenen A, Lemaire K, Quintens R, Van Lommel L, Segal A, Owsianik G, Talavera K, Voets T, Margolskee RF, et al. (2010) Loss of high-frequency glucose-induced $\mathrm{Ca}^{2+}$ oscillations in pancreatic islets correlates with impaired glucose tolerance in Trpm5-/- mice. Proc Natl Acad Sci USA 107:5208-5213.

Corey DP (2006) What is the hair cell transduction channel? J Physiol 576:23-28.

Corey DP, García-Añoveros J, Holt JR, Kwan KY, Lin SY, Vollrath MA, Amalfitano A, Cheung EL, Derfler BH, Duggan A, et al. (2004) TRPA1 is a candidate for the mechanosensitive transduction channel of vertebrate hair cells. Nature 432:723730

Cuervo AM and Dice JF (1996) A receptor for the selective uptake and degradation of proteins by lysosomes. Science 273:501-503.

Damak S, Rong M, Yasumatsu K, Kokrashvili Z, Pérez CA, Shigemura N, Yoshida R, Mosinger B Jr, Glendinning JI, Ninomiya Y, et al. (2006) Trpm5 null mice respond to bitter, sweet, and umami compounds. Chem Senses 31:253-264

Davare MA, Fortin DA, Saneyoshi T, Nygaard S, Kaech S, Banker G, Soderling TR, and Wayman GA (2009) Transient receptor potential canonical 5 channels activate $\mathrm{Ca}^{2+}$ /calmodulin kinase Igamma to promote axon formation in hippocampal neurons. J Neurosci 29:9794-9808.

Davis JB, Gray J, Gunthorpe MJ, Hatcher JP, Davey PT, Overend P, Harries MH, Latcham J, Clapham C, Atkinson K, et al. (2000) Vanilloid receptor-1 is essential for inflammatory thermal hyperalgesia. Nature 405:183-187.

De Blas GA, Darszon A, Ocampo AY, Serrano CJ, Castellano LE, HernándezGonzález EO, Chirinos M, Larrea F, Beltrán C, and Treviño CL (2009) TRPM8, a versatile channel in human sperm. PLoS One 4:e6095.

De Petrocellis L, Harrison S, Bisogno T, Tognetto M, Brandi I, Smith GD, Creminon C, Davis JB, Geppetti P, and Di Marzo V (2001) The vanilloid receptor (VR1) mediated effects of anandamide are potently enhanced by the cAMP-dependent protein kinase. $J$ Neurochem 77:1660-1663.

Deng HX, Klein CJ, Yan J, Shi Y, Wu Y, Fecto F, Yau HJ, Yang Y, Zhai H, Siddique N, et al. (2010) Scapuloperoneal spinal muscular atrophy and CMT2C are allelic disorders caused by alterations in TRPV4. Nat Genet 42:165-169.

Desai BN and Clapham DE (2005) TRP channels and mice deficient in TRP channels. Pflugers Arch 451:11-18.

Dhaka A, Murray AN, Mathur J, Earley TJ, Petrus MJ, and Patapoutian A (2007) TRPM8 is required for cold sensation in mice. Neuron 54:371-378.

Di Palma F, Belyantseva IA, Kim HJ, Vogt TF, Kachar B, and Noben-Trauth K 
(2002) Mutations in Mcoln3 associated with deafness and pigmentation defects in varitint-waddler (Va) mice. Proc Natl Acad Sci USA 99:14994-14999.

Dietrich A, Kalwa H, Storch U, Mederos y Schnitzler M, Salanova B, Pinkenburg O, Dubrovska G, Essin K, Gollasch M, Birnbaumer L, et al. (2007) Pressure-induced and store-operated cation influx in vascular smooth muscle cells is independent of TRPC1. Pflugers Arch 455:465-477.

Dietrich A, Mederos Y Schnitzler M, Gollasch M, Gross V, Storch U, Dubrovska G, Obst M, Yildirim E, Salanova B, Kalwa $\mathrm{H}$, et al. (2005) Increased vascular smooth muscle contractility in TRPC6-/- mice. Mol Cell Biol 25:6980-6989.

Diogenes A, Akopian AN, and Hargreaves KM (2007) NGF up-regulates TRPA1: implications for orofacial pain. J Dent Res 86:550-555.

Docherty RJ, Yeats JC, Bevan S, and Boddeke HW (1996) Inhibition of calcineurin inhibits the desensitization of capsaicin-evoked currents in cultured dorsal root ganglion neurones from adult rats. Pflugers Arch 431:828-837.

Dong XP, Cheng X, Mills E, Delling M, Wang F, Kurz T, and Xu H (2008) The type IV mucolipidosis-associated protein TRPML1 is an endolysosomal iron release channel. Nature 455:992-996.

Dong XP, Wang X, Shen D, Chen S, Liu M, Wang Y, Mills E, Cheng X, Delling M, and Xu H (2009) Activating mutations of the TRPML1 channel revealed by prolinescanning mutagenesis. J Biol Chem 284:32040-32052.

Dorovkov MV and Ryazanov AG (2004) Phosphorylation of annexin I by TRPM7 channel-kinase. J Biol Chem 279:50643-50646.

Du J, Xie J, and Yue L (2009) Intracellular calcium activates TRPM2 and its alternative spliced isoforms. Proc Natl Acad Sci USA 106:7239-7244.

Duncan LM, Deeds J, Hunter J, Shao J, Holmgren LM, Woolf EA, Tepper RI, and Shyjan AW (1998) Down-regulation of the novel gene melastatin correlates with potential for melanoma metastasis. Cancer Res 58:1515-1520.

Earley S, Pauyo T, Drapp R, Tavares MJ, Liedtke W, and Brayden JE (2009) TRPV4-dependent dilation of peripheral resistance arteries influences arterial pressure. Am J Physiol Heart Circ Physiol 297:H1096-H1102.

Ellingson JM, Silbaugh BC, and Brasser SM (2009) Reduced oral ethanol avoidance in mice lacking transient receptor potential channel vanilloid receptor 1 . Behav Genet 39:62-72.

Erler I, Hirnet D, Wissenbach U, Flockerzi V, and Niemeyer BA (2004) $\mathrm{Ca}^{2+}$ selective transient receptor potential $\mathrm{V}$ channel architecture and function require a specific ankyrin repeat. J Biol Chem 279:34456-34463.

Fan HC, Zhang X, and McNaughton PA (2009) Activation of the TRPV4 ion channel is enhanced by phosphorylation. J Biol Chem 284:27884-27891.

Fernandes J, Lorenzo IM, Andrade YN, Garcia-Elias A, Serra SA, FernándezFernández JM, and Valverde MA (2008) IP3 sensitizes TRPV4 channel to the mechano- and osmotransducing messenger $5^{\prime}-6^{\prime}$-epoxyeicosatrienoic acid. J Gen Physiol 131:i2.

Freichel M, Suh SH, Pfeifer A, Schweig U, Trost C, Weissgerber P, Biel M, Philipp S, Freise D, Droogmans G, et al. (2001) Lack of an endothelial store-operated $\mathrm{Ca}^{2+}$ current impairs agonist-dependent vasorelaxation in TRP4-I- mice. Nat Cell Bio 3:121-127.

Gabow PA (1993) Autosomal dominant polycystic kidney disease. $N$ Engl J Med 329:332-342

Gao H, Wang Y, Wegierski T, Skouloudaki K, Pütz M, Fu X, Engel C, Boehlke C Peng H, Kuehn EW, et al. (2010) PRKCSH/80K-H, the protein mutated in polycystic liver disease, protects polycystin-2/TRPP2 against HERP-mediated degradation. Hum Mol Genet 19:16-24.

Gao X, Wu L, and O'Neil RG (2003) Temperature-modulated diversity of TRPV4 channel gating: activation by physical stresses and phorbol ester derivative through protein kinase C-dependent and -independent pathways. $J$ Biol Chem 278:27129-27137.

Gavva NR, Treanor JJ, Garami A, Fang L, Surapaneni S, Akrami A, Alvarez F, Bak A, Darling M, Gore A, et al. (2008) Pharmacological blockade of the vanilloid receptor TRPV1 elicits marked hyperthermia in humans. Pain 136:202-210.

Geng L, Boehmerle W, Maeda Y, Okuhara DY, Tian X, Yu Z, Choe CU, Anyatonwu GI, Ehrlich BE, and Somlo S (2008) Syntaxin 5 regulates the endoplasmic reticulum channel-release properties of polycystin-2. Proc Natl Acad Sci USA 105: 15920-15925.

Geng L, Okuhara D, Yu Z, Tian X, Cai Y, Shibazaki S, and Somlo S (2006) Polycystin-2 traffics to cilia independently of polycystin-1 by using an N-terminal RVxP motif. J Cell Sci 119:1383-1395.

Geppetti P, Materazzi S, and Nicoletti P (2006) The transient receptor potential vanilloid 1: role in airway inflammation and disease. Eur J Pharmacol 533:207214

Gerzanich V, Woo SK, Vennekens R, Tsymbalyuk O, Ivanova S, Ivanov A, Geng Z, Chen Z, Nilius B, Flockerzi V, et al. (2009) De novo expression of Trpm4 initiates secondary hemorrhage in spinal cord injury. Nat Med 15:185-191.

Gevaert T, Vriens J, Segal A, Everaerts W, Roskams T, Talavera K, Owsianik G, Liedtke W, Daelemans D, Dewachter I, et al (2007) Deletion of the transien receptor potential cation channel TRPV4 impairs murine bladder voiding. J Clin Invest 117:3453-3462.

Gibson HE, Edwards JG, Page RS, Van Hook MJ, and Kauer JA (2008) TRPV1 channels mediate long-term depression at synapses on hippocampal interneurons. Neuron 57:746-759.

Gilon P and Henquin JC (2001) Mechanisms and physiological significance of the cholinergic control of pancreatic beta-cell function. Endocr Rev 22:565-604.

Gkika D, Mahieu F, Nilius B, Hoenderop JG, and Bindels RJ (2004) 80K-H as a new $\mathrm{Ca}^{2+}$ sensor regulating the activity of the epithelial $\mathrm{Ca}^{2+}$ channel transient receptor potential cation channel V5 (TRPV5). J Biol Chem 279:26351-26357.

Gonzalez-Perrett S, Batelli M, Kim K, Essafi M, Timpanaro G, Moltabetti N, Reisin IL, Arnaout MA, and Cantiello HF (2002) Voltage dependence and $\mathrm{pH}$ regulation of human polycystin-2-mediated cation channel activity. J Biol Chem 277:2495924966

Gracheva EO, Ingolia NT, Kelly YM, Cordero-Morales JF, Hollopeter G, Chesler AT, Sánchez EE, Perez JC, Weissman JS, and Julius D (2010) Molecular basis of infrared detection by snakes. Nature 464:1006-1011.
Gradilone SA, Masyuk AI, Splinter PL, Banales JM, Huang BQ, Tietz PS, Masyuk TV, and Larusso NF (2007) Cholangiocyte cilia express TRPV4 and detect changes in luminal tonicity inducing bicarbonate secretion. Proc Natl Acad Sci USA 104: 19138-19143.

Greka A, Navarro B, Oancea E, Duggan A, and Clapham DE (2003) TRPC5 is a regulator of hippocampal neurite length and growth cone morphology. Nat $\mathrm{Neu}$ rosci 6:837-845.

Grimm C, Cuajungco MP, van Aken AF, Schnee M, Jörs S, Kros CJ, Ricci AJ, and Heller S (2007) A helix-breaking mutation in TRPML3 leads to constitutive activ ity underlying deafness in the varitint-waddler mouse. Proc Natl Acad Sci USA 104:19583-19588

Grimm C, Jörs S, Saldanha SA, Obukhov AG, Pan B, Oshima K, Cuajungco MP, Chase P, Hodder P, and Heller S (2010) Small molecule activators of TRPML3. Chem Biol 17:135-148.

Grimm C, Kraft R, Sauerbruch S, Schultz G, and Harteneck C (2003) Molecular and functional characterization of the melastatin-related cation channel TRPM3. $J$ Biol Chem 278:21493-21501.

Grimm C, Kraft R, Schultz G, and Harteneck C (2005) Activation of the melastatinrelated cation channel TRPM3 by D-erythro-sphingosine [corrected]. Mol Pharmacol 67:798-805.

Güler AD, Lee H, Iida T, Shimizu I, Tominaga M, and Caterina M (2002) Heatevoked activation of the ion channel, TRPV4. J Neurosci 22:6408-6414.

Guo L, Schreiber TH, Weremowicz S, Morton CC, Lee C, and Zhou J (2000) Identification and characterization of a novel polycystin family member, polycystin-L2, in mouse and human: sequence, expression, alternative splicing, and chromosomal localization. Genomics 64:241-251.

Hamanaka K, Jian MY, Weber DS, Alvarez DF, Townsley MI, Al-Mehdi AB, King JA, Liedtke W, and Parker JC (2007) TRPV4 initiates the acute calciumdependent permeability increase during ventilator-induced lung injury in isolated mouse lungs. Am J Physiol Lung Cell Mol Physiol 293:L923-L932.

Hanaoka K, Qian F, Boletta A, Bhunia AK, Piontek K, Tsiokas L, Sukhatme VP, Guggino WB, and Germino GG (2000) Co-assembly of polycystin-1 and -2 produces unique cation-permeable currents. Nature 408:990-994.

Hara K, Kokubo Y, Ishiura H, Fukuda Y, Miyashita A, Kuwano R, Sasaki R, Goto J, Nishizawa M, Kuzuhara S, et al. (2010) TRPM7 is not associated with amyotrophic lateral sclerosis-parkinsonism dementia complex in the Kii peninsula of Japan. Am J Med Genet B Neuropsychiatr Genet 153B:310-313.

Hara Y, Wakamori M, Ishii M, Maeno E, Nishida M, Yoshida T, Yamada H, Shimizu $\mathrm{S}$, Mori E, Kudoh J, et al. (2002) LTRPC2 $\mathrm{Ca}^{2+}$-permeable channel activated by changes in redox status confers susceptibility to cell death. Mol Cell 9:163-173.

Hartmann J, Dragicevic E, Adelsberger H, Henning HA, Sumser M, Abramowitz J, Blum R, Dietrich A, Freichel M, Flockerzi V, et al. (2008) TRPC3 channels are required for synaptic transmission and motor coordination. Neuron 59:392-398.

Helliwell RJ, McLatchie LM, Clarke M, Winter J, Bevan S, and McIntyre P (1998) Capsaicin sensitivity is associated with the expression of the vanilloid (capsaicin) receptor (VR1) mRNA in adult rat sensory ganglia. Neurosci Lett 250:177-180.

Hermosura MC, Cui AM, Go RC, Davenport B, Shetler CM, Heizer JW, Schmitz C Mocz G, Garruto RM, and Perraud AL (2008) Altered functional properties of a TRPM2 variant in Guamanian ALS and PD. Proc Natl Acad Sci USA 105:1802918034

Hermosura MC, Nayakanti H, Dorovkov MV, Calderon FR, Ryazanov AG, Haymer DS, and Garruto RM (2005) A TRPM7 variant shows altered sensitivity to magnesium that may contribute to the pathogenesis of two Guamanian neurodegenerative disorders. Proc Natl Acad Sci USA 102:11510-11515.

Hill K, Benham CD, McNulty S, and Randall AD (2004) Flufenamic acid is a pH-dependent antagonist of TRPM2 channels. Neuropharmacology 47:450-460.

Hinman A, Chuang HH, Bautista DM, and Julius D (2006) TRP channel activation by reversible covalent modification. Proc Natl Acad Sci USA 103:19564-19568.

Hirnet D, Olausson J, Fecher-Trost C, Bödding M, Nastainczyk W, Wissenbach U, Flockerzi V, and Freichel M (2003) The TRPV6 gene, cDNA and protein. Cell Calcium 33:509-518.

Hisanaga E, Nagasawa M, Ueki K, Kulkarni RN, Mori M, and Kojima I (2009) Regulation of calcium-permeable TRPV2 channel by insulin in pancreatic betacells. Diabetes 58:174-184

Hisatsune C, Kuroda Y, Nakamura K, Inoue T, Nakamura T, Michikawa T, Mizutani A, and Mikoshiba K (2004) Regulation of TRPC 6 channel activity by tyrosine phosphorylation. J Biol Chem 279:18887-18894

Hoenderop JG, van der Kemp AW, Hartog A, van de Graaf SF, van Os CH, Willems $\mathrm{PH}$, and Bindels RJ (1999) Molecular identification of the apical $\mathrm{Ca}^{2+}$ channel in 1, 25-dihydroxyvitamin D3-responsive epithelia. J Biol Chem 274:8375-8378.

Hoenderop JG, van Leeuwen JP, van der Eerden BC, Kersten FF, van der Kemp AW Mérillat AM, Waarsing JH, Rossier BC, Vallon V, Hummler E, et al. (2003) Rena $\mathrm{Ca}^{2+}$ wasting, hyperabsorption, and reduced bone thickness in mice lacking TRPV5. J Clin Invest 112:1906-1914.

Hoenderop JG, Vennekens R, Müller D, Prenen J, Droogmans G, Bindels RJ, and Nilius B (2001) Function and expression of the epithelial $\mathrm{Ca}^{2+}$ ) channel family: comparison of mammalian ECaC1 and 2. J Physiol 537:747-761.

Hofmann T, Chubanov V, Gudermann T, and Montell C (2003) TRPM5 is a voltagemodulated and $\mathrm{Ca}^{2+}{ }^{2+}$-activated monovalent selective cation channel. Curr Bio 13:1153-1158.

Hofmann T, Obukhov AG, Schaefer M, Harteneck C, Gudermann T, and Schultz G (1999) Direct activation of human TRPC6 and TRPC3 channels by diacylglycerol. Nature 397:259-263.

Hofmann T, Schaefer M, Schultz G, and Gudermann T (2000) Cloning, expression and subcellular localization of two novel splice variants of mouse transient receptor potential channel 2. Biochem $J$ 351:115-122.

Howard J and Bechstedt S (2004) Hypothesis: a helix of ankyrin repeats of the NOMPC-TRP ion channel is the gating spring of mechanoreceptors. Curr Biol 14:R224-R226.

Huang AL, Chen X, Hoon MA, Chandrashekar J, Guo W, Tränkner D, Ryba NJ, and 
Zuker CS (2006) The cells and logic for mammalian sour taste detection. Nature 442:934-938.

Huang SM, Bisogno T, Trevisani M, Al-Hayani A, De Petrocellis L, Fezza F, Tognetto M, Petros TJ, Krey JF, Chu CJ, et al. (2002) An endogenous capsaicin-like substance with high potency at recombinant and native vanilloid VR1 receptors. Proc Natl Acad Sci USA 99:8400-8405.

Huang SM, Lee H, Chung MK, Park U, Yu YY, Bradshaw HB, Coulombe PA, Walker JM, and Caterina MJ (2008) Overexpressed transient receptor potential vanilloid 3 ion channels in skin keratinocytes modulate pain sensitivity via prostaglandin E2. J Neurosci 28:13727-13737.

Hwang SW, Cho H, Kwak J, Lee SY, Kang CJ, Jung J, Cho S, Min KH, Suh YG, Kim D, et al. (2000) Direct activation of capsaicin receptors by products of lipoxygenases: endogenous capsaicin-like substances. Proc Natl Acad Sci USA 97:61556160.

Iida T, Moriyama T, Kobata K, Morita A, Murayama N, Hashizume S, Fushiki T, Yazawa S, Watanabe T, and Tominaga M (2003) TRPV1 activation and induction of nociceptive response by a non-pungent capsaicin-like compound, capsiate. Neuropharmacology 44:958-967.

Imura K, Yoshioka T, Hikita I, Tsukahara K, Hirasawa T, Higashino K, Gahara Y, Arimura A, and Sakata T (2007) Influence of TRPV3 mutation on hair growth cycle in mice. Biochem Biophys Res Commun 363:479-483.

Inoue R, Okada T, Onoue H, Hara Y, Shimizu S, Naitoh S, Ito Y, and Mori Y (2001) The transient receptor potential protein homologue TRP6 is the essential component of vascular alpha(1)-adrenoceptor-activated $\mathrm{Ca}^{2+}$-permeable cation channel. Circ Res 88:325-332.

Ishimaru Y, Inada H, Kubota M, Zhuang H, Tominaga M, and Matsunami H (2006) Transient receptor potential family members PKD1L3 and PKD2L1 form a candidate sour taste receptor. Proc Natl Acad Sci USA 103:12569-12574.

Iwata Y, Katanosaka Y, Arai Y, Komamura K, Miyatake K, and Shigekawa M (2003) A novel mechanism of myocyte degeneration involving the $\mathrm{Ca}^{2+}$-permeable growth factor-regulated channel. J Cell Biol 161:957-967.

Iwata Y, Katanosaka Y, Arai Y, Shigekawa M, and Wakabayashi S (2009) Dominantnegative inhibition of $\mathrm{Ca}^{2+}$ influx via TRPV2 ameliorates muscular dystrophy in animal models. Hum Mol Genet 18:824-834.

Jia Y, Zhou J, Tai Y, and Wang Y (2007) TRPC channels promote cerebellar granule neuron survival. Nat Neurosci 10:559-567.

Jiang J, Li M, and Yue L (2005) Potentiation of TRPM7 inward currents by protons. $J$ Gen Physiol 126:137-150.

Jin J, Desai BN, Navarro B, Donovan A, Andrews NC, and Clapham DE (2008) Deletion of Trpm7 disrupts embryonic development and thymopoiesis without altering $\mathrm{Mg}^{2+}$ homeostasis. Science 322:756-760.

Johnson CD, Melanaphy D, Purse A, Stokesberry SA, Dickson P, and Zholos AV (2009) Transient receptor potential melastatin 8 channel involvement in the regulation of vascular tone. Am J Physiol Heart Circ Physiol 296:H1868-H1877.

Jordt SE, Bautista DM, Chuang HH, McKemy DD, Zygmunt PM, Högestätt ED, Meng ID, and Julius D (2004) Mustard oils and cannabinoids excite sensory nerve fibres through the TRP channel ANKTM1. Nature 427:260-265.

Jordt SE, Tominaga M, and Julius D (2000) Acid potentiation of the capsaicin receptor determined by a key extracellular site. Proc Natl Acad Sci USA 97:81348139 .

Jungnickel MK, Marrero H, Birnbaumer L, Lémos JR, and Florman HM (2001) Trp2 regulates entry of $\mathrm{Ca}^{2+}$ into mouse sperm triggered by egg ZP3. Nat Cell Biol 3:499-502.

Kaneko S, Kawakami S, Hara Y, Wakamori M, Itoh E, Minami T, Takada Y, Kume T, Katsuki H, Mori Y, et al. (2006) A critical role of TRPM2 in neuronal cell death by hydrogen peroxide. J Pharmacol Sci 101:66-76.

Kanzaki M, Zhang YQ, Mashima H, Li L, Shibata H, and Kojima I (1999) Translocation of a calcium-permeable cation channel induced by insulin-like growth factor-I. Nat Cell Biol 1:165-170.

Karacsonyi C, Miguel AS, and Puertollano R (2007) Mucolipin-2 localizes to the Arf6-associated pathway and regulates recycling of GPI-APs. Traffic 8:1404-1414.

Karashima Y, Damann N, Prenen J, Talavera K, Segal A, Voets T, and Nilius B (2007) Bimodal action of menthol on the transient receptor potential channel TRPA1. J Neurosci 27:9874-9884.

Karashima Y, Talavera K, Everaerts W, Janssens A, Kwan KY, Vennekens R, Nilius B, and Voets T (2009) TRPA1 acts as a cold sensor in vitro and in vivo. Proc Natl Acad Sci USA 106:1273-1278.

Kaske S, Krasteva G, König P, Kummer W, Hofmann T, Gudermann T, and Chubanov V (2007) TRPM5, a taste-signaling transient receptor potential ion-channel, is a ubiquitous signaling component in chemosensory cells. BMC Neurosci 8:49.

Kim AY, Tang Z, Liu Q, Patel KN, Maag D, Geng Y, and Dong X (2008a) Pirt, a phosphoinositide-binding protein, functions as a regulatory subunit of TRPV1. Cell 133:475-485.

Kim HJ, Li Q, Tjon-Kon-Sang S, So I, Kiselyov K, and Muallem S (2007) Gain-offunction mutation in TRPML3 causes the mouse Varitint-Waddler phenotype. J Biol Chem 282:36138-36142.

Kim HJ, Li Q, Tjon-Kon-Sang S, So I, Kiselyov K, Soyombo AA, and Muallem S (2008b) A novel mode of TRPML3 regulation by extracytosolic $\mathrm{pH}$ absent in the varitint-waddler phenotype. EMBO J 27:1197-1205.

Kim HJ, Soyombo AA, Tjon-Kon-Sang S, So I, and Muallem S (2009) The $\left.\mathrm{Ca}^{2+}{ }^{2+}\right)$ channel TRPML3 regulates membrane trafficking and autophagy. Traffic 10: 1157-1167.

Kim JY, Zeng W, Kiselyov K, Yuan JP, Dehoff MH, Mikoshiba K, Worley PF, and Muallem S (2006) Homer 1 mediates store- and inositol 1,4,5-trisphosphate receptor-dependent translocation and retrieval of TRPC3 to the plasma membrane. $J$ Biol Chem 281:32540-32549.

Kim SJ, Kim YS, Yuan JP, Petralia RS, Worley PF, and Linden DJ (2003) Activation of the TRPC1 cation channel by metabotropic glutamate receptor mGluR1. Nature 426:285-291.

Kimchi T, Xu J, and Dulac C (2007) A functional circuit underlying male sexual behaviour in the female mouse brain. Nature 448:1009-1014.
Kiselyov K, Chen J, Rbaibi Y, Oberdick D, Tjon-Kon-Sang S, Shcheynikov N, Muallem S, and Soyombo A (2005) TRP-ML1 is a lysosomal monovalent cation channel that undergoes proteolytic cleavage. J Biol Chem 280:43218-43223.

Klausen TK, Pagani A, Minassi A, Ech-Chahad A, Prenen J, Owsianik G, Hoffmann EK, Pedersen SF, Appendino G, and Nilius B (2009) Modulation of the transient receptor potential vanilloid channel TRPV4 by 4alpha-phorbol esters: a structureactivity study. J Med Chem 52:2933-2939.

Koike C, Obara T, Uriu Y, Numata T, Sanuki R, Miyata K, Koyasu T, Ueno S, Funabiki K, Tani A, et al. (2010) TRPM1 is a component of the retinal ON bipolar cell transduction channel in the mGluR6 cascade. Proc Natl Acad Sci USA 107: 332-337.

Kokrashvili Z, Mosinger B, and Margolskee RF (2009a) Taste signaling elements expressed in gut enteroendocrine cells regulate nutrient-responsive secretion of gut hormones. Am J Clin Nutr 90:822S-825S.

Kokrashvili Z, Rodriguez D, Yevshayeva V, Zhou H, Margolskee RF, and Mosinger B (2009b) Release of endogenous opioids from duodenal enteroendocrine cells requires Trpm5. Gastroenterology 137:598-606, 606.e1-2.

Köttgen M, Benzing T, Simmen T, Tauber R, Buchholz B, Feliciangeli S, Huber TB, Schermer B, Kramer-Zucker A, Höpker K, et al. (2005) Trafficking of TRPP2 by PACS proteins represents a novel mechanism of ion channel regulation. EMBO J 24:705-716.

Koulen P, Cai Y, Geng L, Maeda Y, Nishimura S, Witzgall R, Ehrlich BE, and Somlo $\mathrm{S}$ (2002) Polycystin-2 is an intracellular calcium release channel. Nat Cell Biol 4:191-197.

Kowase T, Nakazato Y, Yoko-O H, Morikawa A, and Kojima I (2002) Immunohistochemical localization of growth factor-regulated channel (GRC) in human tissues. Endocr J 49:349-355.

Kraft R and Harteneck C (2005) The mammalian melastatin-related transient receptor potential cation channels: an overview. Pflugers Arch 451:204-211.

Krakow D, Vriens J, Camacho N, Luong P, Deixler H, Funari TL, Bacino CA, Irons MB, Holm IA, Sadler L, et al. (2009) Mutations in the gene encoding the calciumpermeable ion channel TRPV4 produce spondylometaphyseal dysplasia, Kozlowski type and metatropic dysplasia. Am J Hum Genet 84:307-315.

Krapivinsky G, Mochida S, Krapivinsky L, Cibulsky SM, and Clapham DE (2006) The TRPM7 ion channel functions in cholinergic synaptic vesicles and affects transmitter release. Neuron 52:485-496.

Kremeyer B, Lopera F, Cox JJ, Momin A, Rugiero F, Marsh S, Woods CG, Jones NG, Paterson KJ, Fricker FR, et al. (2010) A gain-of-function mutation in TRPA1 causes familial episodic pain syndrome. Neuron 66:671-680.

Kruse M, Schulze-Bahr E, Corfield V, Beckmann A, Stallmeyer B, Kurtbay G, Ohmert I, Schulze-Bahr E, Brink P, and Pongs O (2009) Impaired endocytosis of the ion channel TRPM4 is associated with human progressive familial heart block type I. J Clin Invest 119:2737-2744.

Kuniba H, Yoshiura K, Kondoh T, Ohashi H, Kurosawa K, Tonoki H, Nagai T, Okamoto N, Kato M, Fukushima Y, et al. (2009) Molecular karyotyping in 17 patients and mutation screening in 41 patients with Kabuki syndrome. J Hum Genet 54:304-309.

Kuwahara K, Wang Y, McAnally J, Richardson JA, Bassel-Duby R, Hill JA, and Olson EN (2006) TRPC6 fulfills a calcineurin signaling circuit during pathologic cardiac remodeling. J Clin Invest 116:3114-3126.

Kwan HY, Huang Y, and Yao X (2004) Regulation of canonical transient receptor potential isoform 3 (TRPC3) channel by protein kinase G. Proc Natl Acad Sci USA 101:2625-2630.

Kwan KY, Allchorne AJ, Vollrath MA, Christensen AP, Zhang DS, Woolf CJ, and Corey DP (2006) TRPA1 contributes to cold, mechanical, and chemical nociception but is not essential for hair-cell transduction. Neuron 50:277-289.

Kwan KY, Glazer JM, Corey DP, Rice FL, and Stucky CL (2009) TRPA1 modulates mechanotransduction in cutaneous sensory neurons. J Neurosci 29:4808-4819.

Kwon Y, Hofmann T, and Montell C (2007) Integration of phosphoinositide- and calmodulin-mediated regulation of TRPC6. Mol Cell 25:491-503.

Lambers TT, Mahieu F, Oancea E, Hoofd L, de Lange F, Mensenkamp AR, Voets T, Nilius B, Clapham DE, Hoenderop JG, et al. (2006) Calbindin-D28K dynamically controls TRPV5-mediated $\mathrm{Ca}^{2+}$ transport. EMBO J 25:2978-2988.

Lambers TT, Weidema AF, Nilius B, Hoenderop JG, and Bindels RJ (2004) Regulation of the mouse epithelial Ca2(+) channel TRPV 6 by the $\mathrm{Ca}\left({ }^{2+}\right)$-sensor calmodulin. J Biol Chem 279:28855-28861.

Landouré G, Zdebik AA, Martinez TL, Burnett BG, Stanescu HC, Inada H, Shi Y, Taye AA, Kong L, Munns CH, et al. (2010) Mutations in TRPV4 cause CharcotMarie-Tooth disease type 2C. Nat Genet 42:170-174.

Lange I, Yamamoto S, Partida-Sanchez S, Mori Y, Fleig A, and Penner R (2009) TRPM2 functions as a lysosomal $\mathrm{Ca}^{2+}$-release channel in beta cells. Sci Signal 2:ra23.

Latorre R, Zaelzer C, and Brauchi S (2009) Structure-functional intimacies of transient receptor potential channels. Q Rev Biophys 42:201-246.

Launay P, Fleig A, Perraud AL, Scharenberg AM, Penner R, and Kinet JP (2002) TRPM4 is a $\mathrm{Ca}^{2+}$-activated nonselective cation channel mediating cell membrane depolarization. Cell 109:397-407.

Lee H, Iida T, Mizuno A, Suzuki M, and Caterina MJ (2005a) Altered thermal selection behavior in mice lacking transient receptor potential vanilloid 4. J Neurosci 25:1304-1310.

Lee J, Cha SK, Sun TJ, and Huang CL (2005b) PIP2 activates TRPV5 and releases its inhibition by intracellular $\mathrm{Mg}^{2+}$. $J$ Gen Physiol 126:439-451.

Leypold BG, Yu CR, Leinders-Zufall T, Kim MM, Zufall F, and Axel R (2002) Altered sexual and social behaviors in trp2 mutant mice. Proc Natl Acad Sci USA 99: 6376-6381.

Li HS, Xu XZ, and Montell C (1999) Activation of a TRPC3-dependent cation current through the neurotrophin BDNF. Neuron 24:261-273.

Li M, Du J, Jiang J, Ratzan W, Su LT, Runnels LW, and Yue L (2007) Molecular determinants of $\mathrm{Mg}^{2+}$ and $\mathrm{Ca}^{2+}$ permeability and $\mathrm{pH}$ sensitivity in TRPM6 and TRPM7. J Biol Chem 282:25817-25830. 
Li M, Jiang J, and Yue L (2006) Functional characterization of homo- and heteromeric channel kinases TRPM6 and TRPM7. J Gen Physiol 127:525-537.

Li Y, Jia YC, Cui K, Li N, Zheng ZY, Wang YZ, and Yuan XB (2005) Essential role of TRPC channels in the guidance of nerve growth cones by brain-derived neurotrophic factor. Nature 434:894-898.

Li Z, Sergouniotis PI, Michaelides M, Mackay DS, Wright GA, Devery S, Moore AT, Holder GE, Robson AG, and Webster AR (2009) Recessive mutations of the gene TRPM1 abrogate ON bipolar cell function and cause complete congenital stationary night blindness in humans. Am J Hum Genet 85:711-719.

Liedtke W, Choe Y, Martí-Renom MA, Bell AM, Denis CS, Sali A, Hudspeth AJ, Friedman JM, and Heller S (2000) Vanilloid receptor-related osmotically activated channel (VR-OAC), a candidate vertebrate osmoreceptor. Cell 103:525-535.

Liedtke W and Friedman JM (2003) Abnormal osmotic regulation in trpv4-/- mice. Proc Natl Acad Sci USA 100:13698-13703.

Liman ER, Corey DP, and Dulac C (1999) TRP2: a candidate transduction channel for mammalian pheromone sensory signaling. Proc Natl Acad Sci USA 96:57915796

Link TM, Park U, Vonakis BM, Raben DM, Soloski MJ, and Caterina MJ (2010) TRPV2 has a pivotal role in macrophage particle binding and phagocytosis. Nat Immunol 11:232-239.

Lintschinger B, Balzer-Geldsetzer M, Baskaran T, Graier WF, Romanin C, Zhu MX, and Groschner K (2000) Coassembly of Trp1 and Trp3 proteins generates diacylglycerol- and $\mathrm{Ca}^{2+}$-sensitive cation channels. J Biol Chem 275:27799-27805.

Lishko PV, Procko E, Jin X, Phelps CB, and Gaudet R (2007) The ankyrin repeats of TRPV1 bind multiple ligands and modulate channel sensitivity. Neuron 54:905918.

Liu D and Liman ER (2003) Intracellular $\mathrm{Ca}^{2+}$ and the phospholipid PIP2 regulate the taste transduction ion channel TRPM5. Proc Natl Acad Sci USA 100:15160 15165.

Liu D, Zhang Z, and Liman ER (2005) Extracellular acid block and acid-enhanced inactivation of the $\mathrm{Ca}^{2+}$-activated cation channel TRPM5 involve residues in the S3-S4 and S5-S6 extracellular domains. J Biol Chem 280:20691-20699.

Liu X, Cheng KT, Bandyopadhyay BC, Pani B, Dietrich A, Paria BC, Swaim WD, Beech D, Yildrim E, Singh BB, et al. (2007) Attenuation of store-operated $\mathrm{Ca}^{2+}$ current impairs salivary gland fluid secretion in TRPC1(-/-) mice. Proc Nat Acad Sci USA 104:17542-17547.

LopezJimenez ND, Cavenagh MM, Sainz E, Cruz-Ithier MA, Battey JF, and Sullivan SL (2006) Two members of the TRPP family of ion channels, Pkd113 and Pkd211, are co-expressed in a subset of taste receptor cells. J Neurochem 98:68-77.

Lucas P, Ukhanov K, Leinders-Zufall T, and Zufall F (2003) A diacylglycerol-gated cation channel in vomeronasal neuron dendrites is impaired in TRPC2 mutant mice: mechanism of pheromone transduction. Neuron 40:551-561.

Lyall V, Heck GL, Vinnikova AK, Ghosh S, Phan TH, Alam RI, Russell OF, Malik SA, Bigbee JW, and DeSimone JA (2004) The mammalian amiloride-insensitive nonspecific salt taste receptor is a vanilloid receptor-1 variant. J Physiol 558:147-159.

Ma R, Li WP, Rundle D, Kong J, Akbarali HI, and Tsiokas L (2005) PKD2 functions as an epidermal growth factor-activated plasma membrane channel. Mol Cell Biol 25:8285-8298.

Macpherson LJ, Dubin AE, Evans MJ, Marr F, Schultz PG, Cravatt BF, and Patapoutian A (2007a) Noxious compounds activate TRPA1 ion channels through covalent modification of cysteines. Nature 445:541-545

Macpherson LJ, Geierstanger BH, Viswanath V, Bandell M, Eid SR, Hwang S, and Patapoutian A (2005) The pungency of garlic: activation of TRPA1 and TRPV1 in response to allicin. Curr Biol 15:929-934.

Macpherson LJ, Hwang SW, Miyamoto T, Dubin AE, Patapoutian A, and Story GM (2006) More than cool: promiscuous relationships of menthol and other sensory compounds. Mol Cell Neurosci 32:335-343.

Macpherson LJ, Xiao B, Kwan KY, Petrus MJ, Dubin AE, Hwang S, Cravatt B, Corey DP, and Patapoutian A (2007b) An ion channel essential for sensing chemica damage. J Neurosci 27:11412-11415.

Maione S, Cristino L, Migliozzi AL, Georgiou AL, Starowicz K, Salt TE, and Di Marzo V (2009) TRPV1 channels control synaptic plasticity in the developing superior colliculus. J Physiol 587:2521-2535.

Mandadi S, Sokabe T, Shibasaki K, Katanosaka K, Mizuno A, Moqrich A, Patapoutian A, Fukumi-Tominaga T, Mizumura K, and Tominaga M (2009) TRPV3 in keratinocytes transmits temperature information to sensory neurons via ATP. Pflugers Arch 458:1093-1102.

Manzoni M, Monti E, Bresciani R, Bozzato A, Barlati S, Bassi MT, and Borsani G (2004) Overexpression of wild-type and mutant mucolipin proteins in mammalian cells: effects on the late endocytic compartment organization. FEBS Lett 567:219 224.

Maroto R, Raso A, Wood TG, Kurosky A, Martinac B, and Hamill OP (2005) TRPC1 forms the stretch-activated cation channel in vertebrate cells. Nat Cell Biol 7:179 185.

Massullo P, Sumoza-Toledo A, Bhagat H, and Partida-Sánchez S (2006) TRPM channels, calcium and redox sensors during innate immune responses. Semin Cell Dev Biol 17:654-666.

Masuyama R, Vriens J, Voets T, Karashima Y, Owsianik G, Vennekens R, Lieben L, Torrekens S, Moermans K, Vanden Bosch A, et al. (2008) TRPV4-mediated calcium influx regulates terminal differentiation of osteoclasts. Cell Metab 8:257265.

Matsushita M, Kozak JA, Shimizu Y, McLachlin DT, Yamaguchi H, Wei FY, Tomizawa K, Matsui H, Chait BT, Cahalan MD, et al. (2005) Channel function is dissociated from the intrinsic kinase activity and autophosphorylation of TRPM7/ ChaK1. J Biol Chem 280:20793-20803.

McGrath J, Somlo S, Makova S, Tian X, and Brueckner M (2003) Two populations of node monocilia initiate left-right asymmetry in the mouse. Cell 114:61-73.

McKemy DD, Neuhausser WM, and Julius D (2002) Identification of a cold receptor reveals a general role for TRP channels in thermosensation. Nature 416:52-58.

McNamara CR, Mandel-Brehm J, Bautista DM, Siemens J, Deranian KL, Zhao M,
Hayward NJ, Chong JA, Julius D, Moran MM, et al. (2007) TRPA1 mediates formalin-induced pain. Proc Natl Acad Sci USA 104:13525-13530.

McQuillin A, Bass NJ, Kalsi G, Lawrence J, Puri V, Choudhury K, Detera-Wadleigh SD, Curtis D, and Gurling HM (2006) Fine mapping of a susceptibility locus for bipolar and genetically related unipolar affective disorders, to a region containing the C21ORF29 and TRPM2 genes on chromosome 21q22.3. Mol Psychiatry 11: $134-142$

Mizoguchi F, Mizuno A, Hayata T, Nakashima K, Heller S, Ushida T, Sokabe M, Miyasaka N, Suzuki M, Ezura Y, et al. (2008) Transient receptor potential vanilloid 4 deficiency suppresses unloading-induced bone loss. J Cell Physiol 216 $47-53$

Mizuno A, Matsumoto N, Imai M, and Suzuki M (2003) Impaired osmotic sensation in mice lacking TRPV4. Am J Physiol Cell Physiol 285:C96-C101.

Mochizuki T, Wu G, Hayashi T, Xenophontos SL, Veldhuisen B, Saris JJ, Reynolds DM, Cai Y, Gabow PA, Pierides A, et al. (1996) PKD2, a gene for polycystic kidney disease that encodes an integral membrane protein. Science 272:1339-1342.

Monteilh-Zoller MK, Hermosura MC, Nadler MJ, Scharenberg AM, Penner R, and Fleig A (2003) TRPM7 provides an ion channel mechanism for cellular entry of trace metal ions. J Gen Physiol 121:49-60.

Montell C (2006) An exciting release on TRPM7. Neuron 52:395-397.

Moqrich A, Hwang SW, Earley TJ, Petrus MJ, Murray AN, Spencer KS, Andahazy M, Story GM, and Patapoutian A (2005) Impaired thermosensation in mice lacking TRPV3, a heat and camphor sensor in the skin. Science 307:1468-1472.

Moran MM, Xu H, and Clapham DE (2004) TRP ion channels in the nervous system. Curr Opin Neurobiol 14:362-369.

Moreau R, Daoud G, Bernatchez R, Simoneau L, Masse A, and Lafond J (2002) Calcium uptake and calcium transporter expression by trophoblast cells from human term placenta. Biochim Biophys Acta 1564:325-332.

Morgans CW, Zhang J, Jeffrey BG, Nelson SM, Burke NS, Duvoisin RM, and Brown $\mathrm{RL}$ (2009) TRPM1 is required for the depolarizing light response in retinal ONbipolar cells. Proc Natl Acad Sci USA 106:19174-19178.

Munsch T, Freichel M, Flockerzi V, and Pape HC (2003) Contribution of transient receptor potential channels to the control of GABA release from dendrites. Proc Natl Acad Sci USA 100:16065-16070.

Nadler MJ, Hermosura MC, Inabe K, Perraud AL, Zhu Q, Stokes AJ, Kurosaki T, Kinet JP, Penner R, Scharenberg AM, et al. (2001) LTRPC7 is a Mg.ATP-regulated divalent cation channel required for cell viability. Nature 411:590-595.

Nagasawa M, Nakagawa Y, Tanaka S, and Kojima I (2007) Chemotactic peptide fMetLeuPhe induces translocation of the TRPV2 channel in macrophages. $J$ Cell Physiol 210:692-702.

Nagata K, Duggan A, Kumar G, and García-Añoveros J (2005) Nociceptor and hair cell transducer properties of TRPA1, a channel for pain and hearing. $J$ Neurosci 25:4052-4061.

Nakayama H, Wilkin BJ, Bodi I, and Molkentin JD (2006) Calcineurin-dependent cardiomyopathy is activated by TRPC in the adult mouse heart. Faseb $J$ 20:1660 1670.

Nauli SM, Kawanabe Y, Kaminski JJ, Pearce WJ, Ingber DE, and Zhou J (2008) Endothelial cilia are fluid shear sensors that regulate calcium signaling and nitric oxide production through polycystin-1. Circulation 117:1161-1171.

Neeper MP, Liu Y, Hutchinson TL, Wang Y, Flores CM, and Qin N (2007) Activation properties of heterologously expressed mammalian TRPV2: evidence for specie dependence. J Biol Chem 282:15894-15902.

Niemeyer BA, Bergs C, Wissenbach U, Flockerzi V, and Trost C (2001) Competitive regulation of CaT-like-mediated $\mathrm{Ca}^{2+}$ entry by protein kinase $\mathrm{C}$ and calmodulin. Proc Natl Acad Sci USA 98:3600-3605.

Nijenhuis T, Hoenderop JG, van der Kemp AW, and Bindels RJ (2003) Localization and regulation of the epithelial $\mathrm{Ca}^{2+}$ channel TRPV6 in the kidney. $J$ Am Soc Nephrol 14:2731-2740.

Nilius B, Mahieu F, Prenen J, Janssens A, Owsianik G, Vennekens R, and Voets T (2006) The $\mathrm{Ca}^{2+}$-activated cation channel TRPM4 is regulated by phosphatidyl inositol 4,5-biphosphate. EMBO J 25:467-478.

Nilius B and Owsianik G (2010) Transient receptor potential channelopathies. Pflugers Arch 460:437-450.

Nilius B, Prenen J, Droogmans G, Voets T, Vennekens R, Freichel M, Wissenbach U, and Flockerzi V (2003) Voltage dependence of the $\mathrm{Ca}^{2+}$-activated cation channel TRPM4. J Biol Chem 278:30813-30820.

Nilius B, Prenen J, Hoenderop JG, Vennekens R, Hoefs S, Weidema AF, Droogmans $\mathrm{G}$, and Bindels RJ (2002) Fast and slow inactivation kinetics of the $\mathrm{Ca}^{2+}$ channel $\mathrm{ECaC} 1$ and ECaC2 (TRPV5 and TRPV6). Role of the intracellular loop located between transmembrane segments 2 and 3. J Biol Chem 277:30852-30858.

Nilius B, Prenen J, Tang J, Wang C, Owsianik G, Janssens A, Voets T, and Zhu MX (2005) Regulation of the $\mathrm{Ca}^{2+}$ sensitivity of the nonselective cation channe TRPM4. J Biol Chem 280:6423-6433.

Nilius B, Prenen J, Vennekens R, Hoenderop JG, Bindels RJ, and Droogmans G (2001) Modulation of the epithelial calcium channel, ECaC, by intracellular $\mathrm{Ca}^{2+}$ Cell Calcium 29:417-428.

Nilius B, Prenen J, Voets T, and Droogmans G (2004) Intracellular nucleotides and polyamines inhibit the $\mathrm{Ca}^{2+}$-activated cation channel TRPM4b. Pflugers Arch 448:70-75.

Nilius B, Vennekens R, Prenen J, Hoenderop JG, Bindels RJ, and Droogmans G (2000) Whole-cell and single channel monovalent cation currents through the novel rabbit epithelial $\mathrm{Ca}^{2+}$ channel ECaC. J Physiol 527 (Pt 2):239-248.

Nomura H, Turco AE, Pei Y, Kalaydjieva L, Schiavello T, Weremowicz S, Ji W, Morton CC, Meisler M, Reeders ST, et al. (1998) Identification of PKDL, a nove polycystic kidney disease 2-like gene whose murine homologue is deleted in mice with kidney and retinal defects. J Biol Chem 273:25967-25973.

Numazaki M, Tominaga T, Takeuchi K, Murayama N, Toyooka H, and Tominaga M (2003) Structural determinant of TRPV1 desensitization interacts with calmodulin. Proc Natl Acad Sci USA 100:8002-8006.

Oancea E, Vriens J, Brauchi S, Jun J, Splawski I, and Clapham DE (2009) TRPM1 
forms ion channels associated with melanin content in melanocytes. Sci Signal 2:ra21.

Oancea E, Wolfe JT, and Clapham DE (2006) Functional TRPM7 channels accumulate at the plasma membrane in response to fluid flow. Circ Res 98:245-253.

Oberwinkler J, Lis A, Giehl KM, Flockerzi V, and Philipp SE (2005) Alternative splicing switches the divalent cation selectivity of TRPM3 channels. J Biol Chem 280:22540-22548.

Obukhov AG and Nowycky MC (2008) TRPC5 channels undergo changes in gating properties during the activation-deactivation cycle. J Cell Physiol 216:162-171.

Okada T, Inoue R, Yamazaki K, Maeda A, Kurosaki T, Yamakuni T, Tanaka I, Shimizu S, Ikenaka K, Imoto K, et al. (1999) Molecular and functional characterization of a novel mouse transient receptor potential protein homologue TRP7. $\mathrm{Ca}^{2+}$-permeable cation channel that is constitutively activated and enhanced by stimulation of G protein-coupled receptor. J Biol Chem 274:27359-27370.

Okada T, Shimizu S, Wakamori M, Maeda A, Kurosaki T, Takada N, Imoto K, and Mori Y (1998) Molecular cloning and functional characterization of a novel receptor-activated TRP $\mathrm{Ca}^{2+}$ channel from mouse brain. J Biol Chem 273:10279-10287.

Olah ME, Jackson MF, Li H, Perez Y, Sun HS, Kiyonaka S, Mori Y, Tymianski M, and MacDonald JF (2009) $\mathrm{Ca}^{2+}$-dependent induction of TRPM2 currents in hippocampal neurons. J Physiol 587:965-979.

Ordaz B, Tang J, Xiao R, Salgado A, Sampieri A, Zhu MX, and Vaca L (2005) Calmodulin and calcium interplay in the modulation of TRPC5 channel activity. Identification of a novel C-terminal domain for calcium/calmodulin-mediated facilitation. J Biol Chem 280:30788-30796.

Otsuguro K, Tang J, Tang Y, Xiao R, Freichel M, Tsvilovskyy V, Ito S, Flockerzi V, Zhu MX, and Zholos AV (2008) Isoform-specific inhibition of TRPC4 channel by phosphatidylinositol 4,5-bisphosphate. J Biol Chem 283:10026-10036.

Peier AM, Moqrich A, Hergarden AC, Reeve AJ, Andersson DA, Story GM, Earley TJ, Dragoni I, McIntyre P, Bevan S, et al. (2002a) A TRP channel that senses cold stimuli and menthol. Cell 108:705-715.

Peier AM, Reeve AJ, Andersson DA, Moqrich A, Earley TJ, Hergarden AC, Story GM, Colley S, Hogenesch JB, McIntyre P, et al. (2002b) A heat-sensitive TRP channel expressed in keratinocytes. Science 296:2046-2049.

Peng JB, Chen XZ, Berger UV, Vassilev PM, Tsukaguchi H, Brown EM, and Hediger MA (1999) Molecular cloning and characterization of a channel-like transporter mediating intestinal calcium absorption. J Biol Chem 274:22739-22746.

Peng JB, Chen XZ, Berger UV, Weremowicz S, Morton CC, Vassilev PM, Brown EM, and Hediger MA (2000) Human calcium transport protein CaT1. Biochem Biophys Res Commun 278:326-332.

Pérez CA, Huang L, Rong M, Kozak JA, Preuss AK, Zhang H, Max M, and Margolskee RF (2002) A transient receptor potential channel expressed in taste receptor cells. Nat Neurosci 5:1169-1176.

Perraud AL, Fleig A, Dunn CA, Bagley LA, Launay P, Schmitz C, Stokes AJ, Zhu Q, Bessman MJ, Penner R, et al. (2001) ADP-ribose gating of the calcium-permeable LTRPC2 channel revealed by Nudix motif homology. Nature 411:595-599.

Perraud AL, Takanishi CL, Shen B, Kang S, Smith MK, Schmitz C, Knowles HM, Ferraris D, Li W, Zhang J, et al. (2005) Accumulation of free ADP-ribose from mitochondria mediates oxidative stress-induced gating of TRPM2 cation channels. $J$ Biol Chem 280:6138-6148.

Peters C and Mayer A (1998) $\mathrm{Ca}^{2+} /$ calmodulin signals the completion of docking and triggers a late step of vacuole fusion. Nature 396:575-580.

Peters DJ, Spruit L, Saris JJ, Ravine D, Sandkuijl LA, Fossdal R, Boersma J, van Eijk R, Nørby S, and Constantinou-Deltas CD (1993) Chromosome 4 localization of a second gene for autosomal dominant polycystic kidney disease. Nat Genet 5:359362.

Phelps CB, Wang RR, Choo SS, and Gaudet R (2010) Differential regulation of TRPV1, TRPV3, and TRPV4 sensitivity through a conserved binding site on the ankyrin repeat domain. J Biol Chem 285:731-740.

Prawitt D, Monteilh-Zoller MK, Brixel L, Spangenberg C, Zabel B, Fleig A, and Penner R (2003) TRPM5 is a transient $\mathrm{Ca}^{2+}$-activated cation channel responding to rapid changes in $\left[\mathrm{Ca}^{2+}\right]$ i. Proc Natl Acad Sci USA 100:15166-15171.

Premkumar LS and Ahern GP (2000) Induction of vanilloid receptor channel activity by protein kinase C. Nature 408:985-990.

Qian F, Germino FJ, Cai Y, Zhang X, Somlo S, and Germino GG (1997) PKD1 interacts with PKD2 through a probable coiled-coil domain. Nat Genet 16:179183.

Ramsey IS, Delling M, and Clapham DE (2006) An introduction to TRP channels. Annu Rev Physiol 68:619-647.

Reading SA and Brayden JE (2007) Central role of TRPM4 channels in cerebral blood flow regulation. Stroke 38:2322-2328.

Reiser J, Polu KR, Möller CC, Kenlan P, Altintas MM, Wei C, Faul C, Herbert S, Villegas I, Avila-Casado C, et al. (2005) TRPC6 is a glomerular slit diaphragmassociated channel required for normal renal function. Nat Genet 37:739-744.

Riccio A, Li Y, Moon J, Kim KS, Smith KS, Rudolph U, Gapon S, Yao GL, Tsvetkov E, Rodig SJ, et al. (2009) Essential role for TRPC5 in amygdala function and fear-related behavior. Cell 137:761-772.

Rock MJ, Prenen J, Funari VA, Funari TL, Merriman B, Nelson SF, Lachman RS, Wilcox WR, Reyno S, Quadrelli R, et al. (2008) Gain-of-function mutations in TRPV4 cause autosomal dominant brachyolmia. Nat Genet 40:999-1003.

Rohács T, Lopes CM, Michailidis I, and Logothetis DE (2005) PI(4,5)P2 regulates the activation and desensitization of TRPM8 channels through the TRP domain. Nat Neurosci 8:626-634.

Rohacs T and Nilius B (2007) Regulation of transient receptor potential (TRP) channels by phosphoinositides. Pflugers Arch 455:157-168.

Romanovsky AA, Almeida MC, Garami A, Steiner AA, Norman MH, Morrison SF, Nakamura K, Burmeister JJ, and Nucci TB (2009) The transient receptor potential vanilloid-1 channel in thermoregulation: a thermosensor it is not. Pharmacol Rev 61:228-261.

Rong W, Hillsley K, Davis JB, Hicks G, Winchester WJ, and Grundy D (2004) Jejunal afferent nerve sensitivity in wild-type and TRPV1 knockout mice. J Physiol 560: $867-881$.
Rosenbaum T, Gordon-Shaag A, Munari M, and Gordon SE (2004) $\mathrm{Ca}^{2+} /$ calmodulin modulates TRPV1 activation by capsaicin. J Gen Physiol 123:53-62.

Runnels LW, Yue L, and Clapham DE (2001) TRP-PLIK, a bifunctional protein with kinase and ion channel activities. Science 291:1043-1047.

Runnels LW, Yue L, and Clapham DE (2002) The TRPM7 channel is inactivated by PIP(2) hydrolysis. Nat Cell Biol 4:329-336.

Saito M, Hanson PI, and Schlesinger P (2007) Luminal chloride-dependent activation of endosome calcium channels: patch clamp study of enlarged endosomes. $J$ Biol Chem 282:27327-27333.

Samie MA, Grimm C, Evans JA, Curcio-Morelli C, Heller S, Slaugenhaupt SA, and Cuajungco MP (2009) The tissue-specific expression of TRPML2 (MCOLN-2) gene is influenced by the presence of TRPML1. Pflugers Arch 459:79-91.

Sano Y, Inamura K, Miyake A, Mochizuki S, Yokoi H, Matsushime H, and Furuichi $\mathrm{K}$ (2001) Immunocyte $\mathrm{Ca}^{2+}$ influx system mediated by LTRPC2. Science 293:13271330.

Satoh S, Tanaka H, Ueda Y, Oyama J, Sugano M, Sumimoto H, Mori Y, and Makino $\mathrm{N}$ (2007) Transient receptor potential (TRP) protein 7 acts as a G protein-activated $\mathrm{Ca}^{2+}$ channel mediating angiotensin II-induced myocardial apoptosis. Mol Cell Biochem 294:205-215.

Sawada Y, Hosokawa H, Hori A, Matsumura K, and Kobayashi S (2007) Cold sensitivity of recombinant TRPA1 channels. Brain Res 1160:39-46.

Schaefer M, Plant TD, Obukhov AG, Hofmann T, Gudermann T, and Schultz G (2000) Receptor-mediated regulation of the nonselective cation channels TRPC4 and TRPC5. J Biol Chem 275:17517-17526.

Schlingmann KP and Gudermann T (2005) A critical role of TRPM channel-kinase for human magnesium transport. J Physiol 566:301-308.

Schlingmann KP, Weber S, Peters M, Niemann Nejsum L, Vitzthum H, Klingel K, Kratz M, Haddad E, Ristoff E, Dinour D, et al. (2002) Hypomagnesemia with secondary hypocalcemia is caused by mutations in TRPM6, a new member of the TRPM gene family. Nat Genet 31:166-170.

Schmidt M, Dubin AE, Petrus MJ, Earley TJ, and Patapoutian A (2009) Nociceptive signals induce trafficking of TRPA1 to the plasma membrane. Neuron 64:498-509. Schmitz C, Perraud AL, Johnson CO, Inabe K, Smith MK, Penner R, Kurosaki T, Fleig A, and Scharenberg AM (2003) Regulation of vertebrate cellular $\mathrm{Mg}^{2+}$ homeostasis by TRPM7. Cell 114:191-200.

Schoeber JP, Topala CN, Lee KP, Lambers TT, Ricard G, van der Kemp AW, Huynen MA, Hoenderop JG, and Bindels RJ (2008) Identification of Nipsnap1 as a novel auxiliary protein inhibiting TRPV6 activity. Pflugers Arch 457:91-101.

Schoeber JP, Topala CN, Wang X, Diepens RJ, Lambers TT, Hoenderop JG, and Bindels RJ (2006) RGS2 inhibits the epithelial $\mathrm{Ca}^{2+}$ channel TRPV6. J Biol Chem 281:29669-29674.

Sharif-Naeini R, Folgering JH, Bichet D, Duprat F, Lauritzen I, Arhatte M, Jodar M, Dedman A, Chatelain FC, Schulte U, et al. (2009) Polycystin-1 and -2 dosage regulates pressure sensing. Cell 139:587-596.

Shen Y, Heimel JA, Kamermans M, Peachey NS, Gregg RG, and Nawy S (2009) A transient receptor potential-like channel mediates synaptic transmission in rod bipolar cells. J Neurosci 29:6088-6093.

Shi J, Mori E, Mori Y, Mori M, Li J, Ito Y, and Inoue R (2004) Multiple regulation by calcium of murine homologues of transient receptor potential proteins TRPC6 and TRPC7 expressed in HEK293 cells. J Physiol 561:415-432

Shimizu T, Janssens A, Voets T, and Nilius B (2009) Regulation of the murine TRPP3 channel by voltage, $\mathrm{pH}$, and changes in cell volume. Pflugers Arch 457: $795-807$

Shumyatsky GP, Malleret G, Shin RM, Takizawa S, Tully K, Tsvetkov E, Zakharenko SS, Joseph J, Vronskaya S, Yin D, et al. (2005) stathmin, a gene enriched in the amygdala, controls both learned and innate fear. Cell 123:697-709.

Singh BB, Lockwich TP, Bandyopadhyay BC, Liu X, Bollimuntha S, Brazer SC, Combs C, Das S, Leenders AG, Sheng ZH, et al. (2004) VAMP2-dependent exocytosis regulates plasma membrane insertion of TRPC3 channels and contributes to agonist-stimulated $\mathrm{Ca}^{2+}$ influx. Mol Cell 15:635-646.

Slaugenhaupt SA (2002) The molecular basis of mucolipidosis type IV. Curr Mol Med 2:445-450.

Smith GD, Gunthorpe MJ, Kelsell RE, Hayes PD, Reilly P, Facer P, Wright JE, Jerman JC, Walhin JP, Ooi L, et al. (2002) TRPV3 is a temperature-sensitive vanilloid receptor-like protein. Nature 418:186-190.

Smith PL, Maloney KN, Pothen RG, Clardy J, and Clapham DE (2006) Bisandrographolide from Andrographis paniculata activates TRPV4 channels. J Biol Chem 281:29897-29904

Sotomayor M, Corey DP, and Schulten K (2005) In search of the hair-cell gating spring elastic properties of ankyrin and cadherin repeats. Structure 13:669-682

Steenland HW, Ko SW, Wu LJ, and Zhuo M (2006) Hot receptors in the brain. Mol Pain 2:34

Story GM, Peier AM, Reeve AJ, Eid SR, Mosbacher J, Hricik TR, Earley TJ, Hergarden AC, Andersson DA, Hwang SW, et al. (2003) ANKTM1, a TRP-like channel expressed in nociceptive neurons, is activated by cold temperatures. Cell 112:819-829.

Stowers L, Holy TE, Meister M, Dulac C, and Koentges G (2002) Loss of sex discrimination and male-male aggression in mice deficient for TRP2. Science 295: $1493-1500$.

Strotmann R, Harteneck C, Nunnenmacher K, Schultz G, and Plant TD (2000) OTRPC4, a nonselective cation channel that confers sensitivity to extracellular osmolarity. Nat Cell Biol 2:695-702.

Strotmann R, Schultz G, and Plant TD (2003) $\mathrm{Ca}^{2+}$-dependent potentiation of the nonselective cation channel TRPV4 is mediated by a C-terminal calmodulin binding site. J Biol Chem 278:26541-26549.

Strübing C, Krapivinsky G, Krapivinsky L, and Clapham DE (2001) TRPC1 and TRPC5 form a novel cation channel in mammalian brain. Neuron 29:645-655.

Strübing C, Krapivinsky G, Krapivinsky L, and Clapham DE (2003) Formation of novel TRPC channels by complex subunit interactions in embryonic brain. J Biol Chem 278:39014-39019.

Sugiura T, Tominaga M, Katsuya H, and Mizumura K (2002) Bradykinin lowers the 
threshold temperature for heat activation of vanilloid receptor 1. J Neurophysiol 88:544-548.

Sun HS, Jackson MF, Martin LJ, Jansen K, Teves L, Cui H, Kiyonaka S, Mori Y, Jones M, Forder JP, et al. (2009) Suppression of hippocampal TRPM7 protein prevents delayed neuronal death in brain ischemia. Nat Neurosci 12:1300-1307. Sun M, Goldin E, Stahl S, Falardeau JL, Kennedy JC, Acierno JS, Jr., Bove C, Kaneski CR, Nagle J, Bromley MC, Colman M, Schiffmann R, and Slaugenhaupt SA (2000) Mucolipidosis type IV is caused by mutations in a gene encoding a novel transient receptor potential channel. Hum Mol Genet 9:2471-2478.

Sutton KA, Jungnickel MK, Ward CJ, Harris PC, and Florman HM (2006) Func tional characterization of PKDREJ, a male germ cell-restricted polycystin. $J$ Cell Physiol 209:493-500.

Suzuki M, Ishibashi K, Ooki G, Tsuruoka S, and Imai M (2000) Electrophysiologic characteristics of the Ca-permeable channels, $\mathrm{ECaC}$ and $\mathrm{CaT}$, in the kidney. Biochem Biophys Res Commun 274:344-349.

Suzuki M, Mizuno A, Kodaira K, and Imai M (2003) Impaired pressure sensation in mice lacking TRPV4. J Biol Chem 278:22664-22668.

Suzuki Y, Kovacs CS, Takanaga H, Peng JB, Landowski CP, and Hediger MA (2008) Calcium channel TRPV6 is involved in murine maternal-fetal calcium transport. $J$ Bone Miner Res 23:1249-1256.

Talavera K, Nilius B, and Voets T (2008) Neuronal TRP channels: thermometers, pathfinders and life-savers. Trends Neurosci 31:287-295.

Talavera K, Yasumatsu K, Voets T, Droogmans G, Shigemura N, Ninomiya Y Margolskee RF, and Nilius B (2005) Heat activation of TRPM5 underlies therma sensitivity of sweet taste. Nature 438:1022-1025.

Tang Y, Tang J, Chen Z, Trost C, Flockerzi V, Li M, Ramesh V, and Zhu MX (2000) Association of mammalian trp 4 and phospholipase $\mathrm{C}$ isozymes with a PDZ domaincontaining protein, NHERF. J Biol Chem 275:37559-37564.

Taylor-Clark TE, Undem BJ, Macglashan DW, Jr., Ghatta S, Carr MJ, and McAlexander MA (2008) Prostaglandin-induced activation of nociceptive neurons via direct interaction with transient receptor potential A1 (TRPA1). Mol Pharmacol 73:274-281.

Thorneloe KS, Sulpizio AC, Lin Z, Figueroa DJ, Clouse AK, McCafferty GP, Chendrimada TP, Lashinger ES, Gordon E, Evans L, et al. (2008) $N$-((1S)-1-\{[4-((2S)2-\{[(2,4-dichlorophenyl)sulfonyl]amino\}-3-hydroxypropa noyl)-1-piperazinyl]carbonyl\}-3-methylbutyl)-1-benzothiophene-2-carboxamide (GSK1016790A), a nove and potent transient receptor potential vanilloid 4 channel agonist induces urinary bladder contraction and hyperactivity: Part I. J Pharmacol Exp Ther 326:432-442.

Thyagarajan B, Benn BS, Christakos S, and Rohacs T (2009) Phospholipase Cmediated regulation of transient receptor potential vanilloid 6 channels: implications in active intestinal $\mathrm{Ca}^{2+}$ transport. Mol Pharmacol 75:608-616.

Thyagarajan B, Lukacs V, and Rohacs T (2008) Hydrolysis of phosphatidylinositol 4,5-bisphosphate mediates calcium-induced inactivation of TRPV6 channels. J Biol Chem 283:14980-14987.

Tiruppathi C, Freichel M, Vogel SM, Paria BC, Mehta D, Flockerzi V, and Malik AB (2002) Impairment of store-operated $\mathrm{Ca}^{2+}$ entry in TRPC4(-/-) mice interferes with increase in lung microvascular permeability. Circ Res 91:70-76.

Todaka H, Taniguchi J, Satoh J, Mizuno A, and Suzuki M (2004) Warm temperaturesensitive transient receptor potential vanilloid 4 (TRPV4) plays an essential role in thermal hyperalgesia. J Biol Chem 279:35133-35138.

Togashi K, Hara Y, Tominaga T, Higashi T, Konishi Y, Mori Y, and Tominaga M (2006) TRPM2 activation by cyclic ADP-ribose at body temperature is involved in insulin secretion. EMBO J 25:1804-1815.

Tominaga M, Caterina MJ, Malmberg AB, Rosen TA, Gilbert H, Skinner K, Raumann BE, Basbaum AI, and Julius D (1998) The cloned capsaicin receptor integrates multiple pain-producing stimuli. Neuron 21:531-543.

Torra R, Badenas C, Pérez-Oller L, Luis J, Millán S, Nicolau C, Oppenheimer F, Milà M, and Darnell A (2000) Increased prevalence of polycystic kidney disease type 2 among elderly polycystic patients. Am J Kidney Dis 36:728-734.

Trebak M (2010) The puzzling role of TRPC3 channels in motor coordination. Pflugers Arch 459:369-375.

Trebak M, Hempel N, Wedel BJ, Smyth JT, Bird GS, and Putney JW Jr (2005) Negative regulation of TRPC3 channels by protein kinase C-mediated phosphor ylation of serine 712. Mol Pharmacol 67:558-563.

Trebak M, Lemonnier L, Smyth JT, Vazquez G, and Putney JW Jr (2007) Phospholipase C-coupled receptors and activation of TRPC channels. Handb Exp Pharmacol (179):593-614

Trebak M, St J Bird G, McKay RR, Birnbaumer L, and Putney JW Jr (2003) Signaling mechanism for receptor-activated canonical transient receptor potential 3 (TRPC3) channels. J Biol Chem 278:16244-16252.

Trevisani M, Siemens J, Materazzi S, Bautista DM, Nassini R, Campi B, Imamachi $\mathrm{N}$, Andrè E, Patacchini R, Cottrell GS, et al. (2007) 4-Hydroxynonenal, an endogenous aldehyde, causes pain and neurogenic inflammation through activation of the irritant receptor TRPA1. Proc Natl Acad Sci USA 104:13519-13524.

Tsavaler L, Shapero MH, Morkowski S, and Laus R (2001) Trp-p8, a novel prostatespecific gene, is up-regulated in prostate cancer and other malignancies and shares high homology with transient receptor potential calcium channel proteins. Cancer Res 61:3760-3769.

Tsiokas L, Kim E, Arnould T, Sukhatme VP, and Walz G (1997) Homo- and heterodimeric interactions between the gene products of PKD1 and PKD2. Proc Natl Acad Sci USA 94:6965-6970.

Ullrich ND, Voets T, Prenen J, Vennekens R, Talavera K, Droogmans G, and Nilius $\mathrm{B}$ (2005) Comparison of functional properties of the $\mathrm{Ca}^{2+}$-activated cation channels TRPM4 and TRPM5 from mice. Cell Calcium 37:267-278.

van Aken AF, Atiba-Davies M, Marcotti W, Goodyear RJ, Bryant JE, Richardson GP Noben-Trauth K and Kros CJ (2008) TRPML3 mutations cause impaired mechano-electrical transduction and depolarization by an inward-rectifier cation current in auditory hair cells of varitint-waddler mice. J Physiol 586:5403-5418

van de Graaf SF, van der Kemp AW, van den Berg D, van Oorschot M, Hoenderop $\mathrm{JG}$, and Bindels RJ (2006) Identification of BSPRY as a novel auxiliary protein inhibiting TRPV5 activity. $J$ Am Soc Nephrol 17:26-30. van der Eerden BC, Hoenderop JG, de Vries TJ, Schoenmaker T, Buurman CJ, Uitterlinden AG, Pols HA, Bindels RJ, and van Leeuwen JP (2005) The epithelial $\mathrm{Ca}^{2+}$ channel TRPV5 is essential for proper osteoclastic bone resorption. Proc Nat Acad Sci USA 102:17507-17512.

van Genderen MM, Bijveld MM, Claassen YB, Florijn RJ, Pearring JN, Meire FM, McCall MA, Riemslag FC, Gregg RG, Bergen AA, et al. (2009) Mutations in TRPM1 are a common cause of complete congenital stationary night blindness. Am J Hum Genet 85:730-736.

van Rossum DB, Patterson RL, Sharma S, Barrow RK, Kornberg M, Gill DL, and Snyder SH (2005) Phospholipase Cgamma1 controls surface expression of TRPC3 through an intermolecular PH domain. Nature 434:99-104.

Vannier B, Peyton M, Boulay G, Brown D, Qin N, Jiang M, Zhu X, and Birnbaumer $\mathrm{L}$ (1999) Mouse trp2, the homologue of the human trpc2 pseudogene, encodes mTrp2, a store depletion-activated capacitative $\mathrm{Ca}^{2+}$ entry channel. Proc Natl Acad Sci USA 96:2060-2064.

Vassilev PM, Guo L, Chen XZ, Segal Y, Peng JB, Basora N, Babakhanlou H, Cruger G, Kanazirska M, Ye Cp, et al. (2001) Polycystin-2 is a novel cation channel implicated in defective intracellular $\mathrm{Ca}^{2+}$ homeostasis in polycystic kidney disease. Biochem Biophys Res Commun 282:341-350.

Vazquez G, Wedel BJ, Kawasaki BT, Bird GS, and Putney JW, Jr. (2004) Obligatory role of Src kinase in the signaling mechanism for TRPC3 cation channels. J Biol Chem 279:40521-40528.

Venkatachalam K, Long AA, Elsaesser R, Nikolaeva D, Broadie K, and Montell C (2008) Motor deficit in a Drosophila model of mucolipidosis type IV due to defective clearance of apoptotic cells. Cell 135:838-851.

Venkatachalam K and Montell C (2007) TRP channels. Annu Rev Biochem 76:387417 .

Venkatachalam K, Zheng F, and Gill DL (2003) Regulation of canonical transient receptor potential (TRPC) channel function by diacylglycerol and protein kinase $\mathrm{C}$ $J$ Biol Chem 278:29031-29040.

Vennekens R, Hoenderop JG, Prenen J, Stuiver M, Willems PH, Droogmans G, Nilius B, and Bindels RJ (2000) Permeation and gating properties of the novel epithelial $\mathrm{Ca}^{\left({ }^{2+}\right.}$ ) channel. J Biol Chem 275:3963-3969.

Vennekens R, Olausson J, Meissner M, Bloch W, Mathar I, Philipp SE, Schmitz F, Weissgerber P, Nilius B, Flockerzi V, et al. (2007) Increased IgE-dependent mast cell activation and anaphylactic responses in mice lacking the calcium-activated nonselective cation channel TRPM4. Nat Immunol 8:312-320.

Venugopal B, Browning MF, Curcio-Morelli C, Varro A, Michaud N, Nanthakumar N, Walkley SU, Pickel J, and Slaugenhaupt SA (2007) Neurologic, gastric, and opthalmologic pathologies in a murine model of mucolipidosis type IV. Am J Hum Genet 81:1070-1083.

Venugopal B, Mesires NT, Kennedy JC, Curcio-Morelli C, Laplante JM, Dice JF, and Slaugenhaupt SA (2009) Chaperone-mediated autophagy is defective in mucolipidosis type IV. J Cell Physiol 219:344-353.

Voets T, Droogmans G, Wissenbach U, Janssens A, Flockerzi V, and Nilius B (2004a) The principle of temperature-dependent gating in cold- and heat-sensitive TRP channels. Nature 430:748-754.

Voets T, Janssens A, Prenen J, Droogmans G, and Nilius B (2003) $\mathrm{Mg}^{2+}$-dependent gating and strong inward rectification of the cation channel TRPV6. J Gen Physiol 121:245-260

Voets T and Nilius B (2007) Modulation of TRPs by PIPs. J Physiol 582:939-944.

Voets T, Nilius B, Hoefs S, van der Kemp AW, Droogmans G, Bindels RJ, and Hoenderop JG (2004b) TRPM6 forms the $\mathrm{Mg}^{2+}$ influx channel involved in intestinal and renal $\mathrm{Mg}^{2+}$ absorption. J Biol Chem 279:19-25.

Voets T, Owsianik G, Janssens A, Talavera K, and Nilius B (2007) TRPM8 voltage sensor mutants reveal a mechanism for integrating thermal and chemical stimuli. Nat Chem Biol 3:174-182.

Voets T, Prenen J, Fleig A, Vennekens R, Watanabe H, Hoenderop JG, Bindels RJ, Droogmans G, Penner R, and Nilius B (2001) CaT1 and the calcium releaseactivated calcium channel manifest distinct pore properties. J Biol Chem 276: 47767-47770.

Vogel P, Read R, Hansen GM, Freay LC, Zambrowicz BP, and Sands AT (2010) Situs inversus and related ciliopathies in Dpcd-/-, Pkd111-/- and Nme7-/- mice. Ve Pathol 47:120-131.

Vriens J, Appendino G, and Nilius B (2009) Pharmacology of vanilloid transient receptor potential cation channels. Mol Pharmacol 75:1262-1279.

Vriens J, Owsianik G, Fisslthaler B, Suzuki M, Janssens A, Voets T, Morisseau C Hammock BD, Fleming I, Busse R, et al. (2005) Modulation of the Ca2 permeable cation channel TRPV4 by cytochrome P450 epoxygenases in vascular endothelium. Circ Res 97:908-915.

Vriens J, Watanabe H, Janssens A, Droogmans G, Voets T, and Nilius B (2004) Cell swelling, heat, and chemical agonists use distinct pathways for the activation of the cation channel TRPV4. Proc Natl Acad Sci USA 101:396-401.

Wagner TF, Loch S, Lambert S, Straub I, Mannebach S, Mathar I, Düfer M, Lis A Flockerzi V, Philipp SE, et al. (2008) Transient receptor potential M3 channels are ionotropic steroid receptors in pancreatic beta cells. Nat Cell Biol 10:1421-1430

Walder RY, Landau D, Meyer P, Shalev H, Tsolia M, Borochowitz Z, Boettger MB, Beck GE, Englehardt RK, Carmi R, et al. (2002) Mutation of TRPM6 causes familial hypomagnesemia with secondary hypocalcemia. Nat Genet 31:171-174.

Walder RY, Yang B, Stokes JB, Kirby PA, Cao X, Shi P, Searby CC, Husted RF, and Sheffield VC (2009) Mice defective in Trpm6 show embryonic mortality and neural tube defects. Hum Mol Genet 18:4367-4375.

Wang YY, Chang RB, Waters HN, McKemy DD, and Liman ER (2008) The nociceptor ion channel TRPA1 is potentiated and inactivated by permeating calcium ions. $J$ Biol Chem 283:32691-32703.

Watanabe H, Vriens J, Prenen J, Droogmans G, Voets T, and Nilius B (2003) Anandamide and arachidonic acid use epoxyeicosatrienoic acids to activate TRPV4 channels. Nature 424:434-438.

Watanabe H, Vriens J, Suh SH, Benham CD, Droogmans G, and Nilius B (2002) Heat-evoked activation of TRPV4 channels in a HEK293 cell expression system and in native mouse aorta endothelial cells. J Biol Chem 277:47044-47051. 
Wegierski T, Lewandrowski U, Müller B, Sickmann A, and Walz G (2009) Tyrosine phosphorylation modulates the activity of TRPV4 in response to defined stimuli. J Biol Chem 284:2923-2933.

Whitlock MC (1995) Two-locus drift with sex chromosomes: the partitioning and conversion of variance in subdivided populations. Theor Popul Biol 48:44-64

Winn MP, Conlon PJ, Lynn KL, Farrington MK, Creazzo T, Hawkins AF, Daskalakis N, Kwan SY, Ebersviller S, Burchette JL, et al. (2005) A mutation in the TRPC6 cation channel causes familial focal segmental glomerulosclerosis. Science 308: 1801-1804.

Wissenbach U, Schroth G, Philipp S, and Flockerzi V (1998) Structure and mRNA expression of a bovine trp homologue related to mammalian trp2 transcripts. FEBS Lett 429:61-66.

Wu G, Markowitz GS, Li L, D’Agati VD, Factor SM, Geng L, Tibara S, Tuchman J, Cai Y, Park JH, van Adelsberg J, Hou H, Jr., Kucherlapati R, Edelmann W, and Somlo S (2000) Cardiac defects and renal failure in mice with targeted mutations in $\mathrm{Pkd}$ 2. Nat Genet 24:75-78.

Xu H, Delling M, Jun JC, and Clapham DE (2006) Oregano, thyme and clove-derived flavors and skin sensitizers activate specific TRP channels. Nat Neurosci 9:628635.

Xu H, Delling M, Li L, Dong X, and Clapham DE (2007) Activating mutation in a mucolipin transient receptor potential channel leads to melanocyte loss in varitintwaddler mice. Proc Natl Acad Sci USA 104:18321-18326.

Xu H, Ramsey IS, Kotecha SA, Moran MM, Chong JA, Lawson D, Ge P, Lilly J, Silos-Santiago I, Xie Y, et al. (2002) TRPV3 is a calcium-permeable temperaturesensitive cation channel. Nature 418:181-186.

Xu SZ, Sukumar P, Zeng F, Li J, Jairaman A, English A, Naylor J, Ciurtin C, Majeed Y, Milligan CJ, et al. (2008) TRPC channel activation by extracellular thioredoxin. Nature 451:69-72.

Xu XZ, Moebius F, Gill DL, and Montell C (2001) Regulation of melastatin, a TRP-related protein, through interaction with a cytoplasmic isoform. Proc Natl Acad Sci USA 98:10692-10697.

Yamaguchi H, Matsushita M, Nairn AC, and Kuriyan J (2001) Crystal structure of the atypical protein kinase domain of a TRP channel with phosphotransferase activity. Mol Cell 7:1047-1057.

Yamamoto S, Shimizu S, Kiyonaka S, Takahashi N, Wajima T, Hara Y, Negoro T, Hiroi T, Kiuchi Y, Okada T, et al. (2008) TRPM2-mediated $\mathrm{Ca}^{2+}$ influx induces chemokine production in monocytes that aggravates inflammatory neutrophil infiltration. Nat Med 14:738-747.

Yoshida T, Inoue R, Morii T, Takahashi N, Yamamoto S, Hara Y, Tominaga M, Shimizu S, Sato Y, and Mori Y (2006) Nitric oxide activates TRP channels by cysteine S-nitrosylation. Nat Chem Biol 2:596-607.

Yu FH, Yarov-Yarovoy V, Gutman GA, and Catterall WA (2005) Overview of molec- ular relationships in the voltage-gated ion channel superfamily. Pharmacol Rev 57:387-395.

Yu Y, Ulbrich MH, Li MH, Buraei Z, Chen XZ, Ong AC, Tong L, Isacoff EY, and Yang $\mathrm{J}$ (2009) Structural and molecular basis of the assembly of the TRPP2/PKD1 complex. Proc Natl Acad Sci USA 106:11558-11563.

Yue L, Peng JB, Hediger MA, and Clapham DE (2001) CaT1 manifests the pore properties of the calcium-release-activated calcium channel. Nature 410:705-709.

Zeevi DA, Frumkin A, Offen-Glasner V, Kogot-Levin A, and Bach G (2009) A potentially dynamic lysosomal role for the endogenous TRPML proteins. J Pathol 219:153-162.

Zhang DX, Mendoza SA, Bubolz AH, Mizuno A, Ge ZD, Li R, Warltier DC, Suzuki M, and Gutterman DD (2009) Transient receptor potential vanilloid type 4-deficient mice exhibit impaired endothelium-dependent relaxation induced by acetylcholine in vitro and in vivo. Hypertension 53:532-538.

Zhang L and Barritt GJ (2004) Evidence that TRPM8 is an androgen-dependent $\mathrm{Ca}^{2+}$ channel required for the survival of prostate cancer cells. Cancer Res 64: 8365-8373.

Zhang Y, Hoon MA, Chandrashekar J, Mueller KL, Cook B, Wu D, Zuker CS, and Ryba NJ (2003) Coding of sweet, bitter, and umami tastes: different receptor cells sharing similar signaling pathways. Cell 112:293-301.

Zhang Z, Okawa H, Wang Y, and Liman ER (2005) Phosphatidylinositol 4,5bisphosphate rescues TRPM4 channels from desensitization. J Biol Chem 280: 39185-39192.

Zhou J (2009) Polycystins and primary cilia: primers for cell cycle progression. Annu Rev Physiol 71:83-113.

Zhou J, Du W, Zhou K, Tai Y, Yao H, Jia Y, Ding Y, and Wang Y (2008) Critical role of TRPC6 channels in the formation of excitatory synapses. Nat Neurosci 11:741743

Zhu MX (2005) Multiple roles of calmodulin and other $\mathrm{Ca}^{2+}$ )-binding proteins in the functional regulation of TRP channels. Pflugers Arch 451:105-115.

Zhuang L, Peng JB, Tou L, Takanaga H, Adam RM, Hediger MA, and Freeman MR (2002) Calcium-selective ion channel, CaT1, is apically localized in gastrointestinal tract epithelia and is aberrantly expressed in human malignancies. Lab Invest 82:1755-1764.

Zitt C, Zobel A, Obukhov AG, Harteneck C, Kalkbrenner F, Lückhoff A, and Schultz $\mathrm{G}$ (1996) Cloning and functional expression of a human $\mathrm{Ca}^{2+}$-permeable cation channel activated by calcium store depletion. Neuron 16:1189-1196.

Zurborg S, Yurgionas B, Jira JA, Caspani O, and Heppenstall PA (2007) Direct activation of the ion channel TRPA1 by $\mathrm{Ca}^{2+}$. Nat Neurosci 10:277-279.

Zygmunt PM, Petersson J, Andersson DA, Chuang H, Sørgård M, Di Marzo V, Julius $\mathrm{D}$, and Högestätt ED (1999) Vanilloid receptors on sensory nerves mediate the vasodilator action of anandamide. Nature 400:452-457. 